COMPONENTES DA PRODUÇÃO E DO RENDIMENTO DE AMENDOIM (Arachis hypogaea L.) SUBMETIDO À CALAGEM E A DIEERENTES DOSES DE GESSO AGRÍCOLA, COMBINADOS A ÉPOCAS E MODOS DE APLICAÇÃO

\author{
RODRIGO EGÉA DE MIRANDA \\ Engenheiro Agrônomo
}

Orientador: Prof. Dr. Gil Miguel de Sousa Câmara

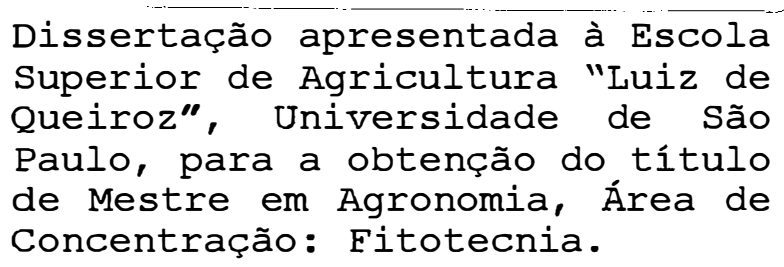

P I R A C I C A B A

Estado de São Paulo - Brasil

Janeiro - 1997 
Dados Internacionais de Catalogação na Publicação (CIP)

\section{DIVISĀO DE BIBLIOTECA E DOCUMENTAÇĀO - Campus "Luiz de Queiroz"/USP}

Miranda, Rodrigo Egéa de

Componentes da produção e do rendimento de amendoim (Arachis hypogaea L.) submetido à calagem e a diferentes doses de gesso agricola, combinädos a épocas e modos de aplicação / Rodrigo Egéa de Miranda. - - Piracicaba, 1997.

$102 \mathrm{p}$.

Dissertação (mestrado) - - Escola Superior de Agricultura Luiz de Queiroz, 1997. Bibliografia.

1. Amendoim 2. Calagem 3. Gesso agricola 4. Produção 5. Rendimento I. Título

CDD 635.659 
COMPONENTES DA PRODUÇÃO E DO RENDIMENTO DE AMENDOIM (Arachis hypogaea L.) SUBMETIDO À CALAGEM E A DIFERENTES DOSES DE GESSO AGRÍCOLA, COMBINADOS A ÉPOCAS E MODOS DE APLICAÇÃO

Aprovada em: 21.03.1997

Comissão julgadora:

Prof. Dr. Gil Miguel de Sousa Câmara

Prof. Dr. Marcos Silveira Bernardes

Prof. Dr. Godofredo César Vitti

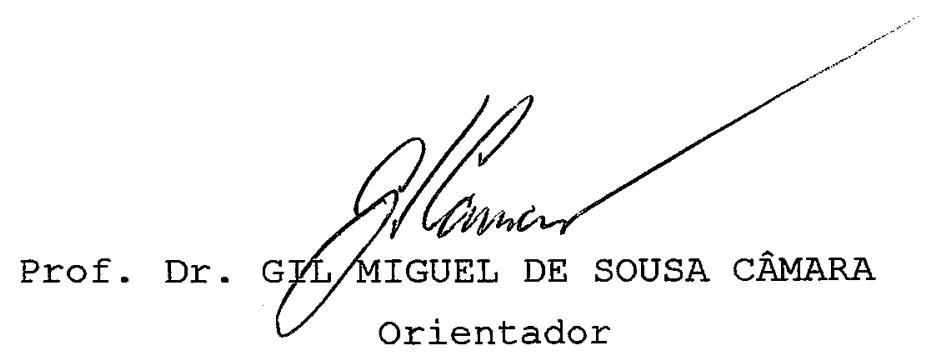


"Não basta o conhecimento da ciência aplicada para que o vosso trabalho traga mais beneficios ao homem. O principal objetivo de todo o progresso técnico deve ser o homem e o seu destino... para que as criações da nossa inteligência possam ser uma bênção, e nunca uma maldição para a humanidade. Nunca esqueçais este principio quando vos concentrardes nos vossos diagramas e equações."

Albert Einstein

À minha mãe MARIA LUIZA, pelo carinho e dedicação e

$\grave{A}$ amiga CECI, Companheira neste período Esalqueano

Dedico este trabalho 
Ao Amigo e Mestre Gil Miguel de Sousa Câmara, pela orientação, apoio e amizade durante os cursos de graduação e pós-graduação;

Aos professores do Curso de Pós-graduação da Escola Superior de Agricultura "Luiz de Queiroz", pela atenção e pelos ensinamentos oferecidos;

Aos funcionários e estagiários do Departamento de Agricultura, pela colaboração direta ou indireta na realização deste trabalho;

À Profa. Dra. Maria Cristina Stolf Nogueira, pelo carinho e auxílio nas análises estatísticas;

À Escola Superior de Agricultura "Luiz de Queiroz", da Universidade de São Paulo, pela oportunidade concedida;

À Fundação Coordenação de Aperfeiçoamento de Pessoal de Nível Superior - CAPES, pela concessão de bolsa de estudos, para a realização do curso;

À Fundação de Amparo à Pesquisa do Estado de São Paulo - FAPESP, pela concessão de auxílio à pesquisa que possibilitou a realização deste trabalho;

Ao Prof. Dr. Evaristo Marzabal Neves e ao Prof. Dr. Geraldo José Aparecido Dario, pela colaboração e amizade;

Aos Eng으 Agr으 Leandro Mees dos Santos, Maria Cristina spinola e Luiz Carlos Monobi e aos acadêmicos Nivea, Roberto, Rodrigo e Simoni, pela colaboração na realização deste trabalho;

Aos meus familiares, pelo incentivo e apoio durante esta caminhada;

Aos demais que, embora não mencionados, contribuíram para a realização deste trabalho: 
1. INTRODUÇÃO .......................... 1

2. REVISÃo DE LITERATURA ....................4

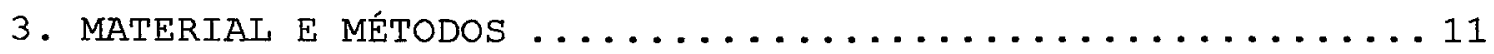

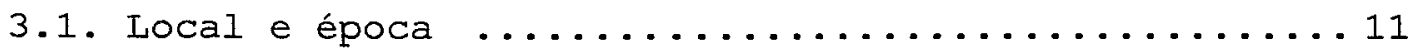

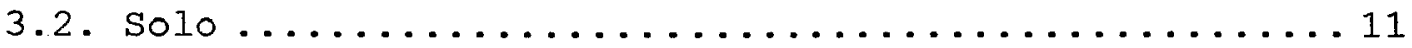

3.3. Cultivar .......................... 12

3.4. Instalação dos experimentos ............... 12

3.5. Tratamentos ......................... 13

3.6. Condução do experimento .................. 16

3.7. Características avaliadas ................. 16

3.7.1. Indice de velocidade de emergência ....... 16

3.7.2. População inicial e final ............ 17

3.7.3. Análise foliar.................. 17

3.7.4. Análise química do solo..............17

3.7.5. Número e massa total de vagens por metro.... 18

3.7.6. Número e massa de vagens comerciais por

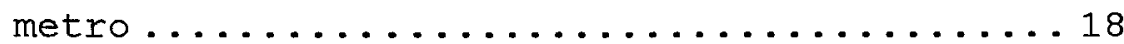

3.7.7. Número e massa total de vagens por planta... 18

3.7.8. Número e massa de vagens comerciais por planta .......................... 18

3.7.9. Número e massa total de grãos por metro.... 19

3.7.10. Número e massa de grãos comerciais por

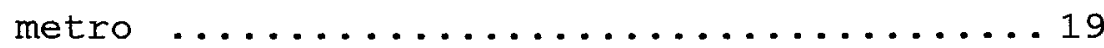

3.7.11. Número e massa total de grãos por planta .. 19

3.7.12. Número e massa de grãos comerciais por

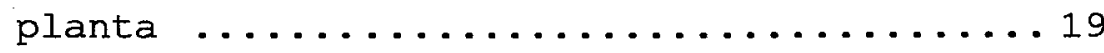

3.7.13. Rendimento total de grãos comerciais por vagem .......................... 19

3.7.14. Rendimento agrícola ................. 20 
3.8. Delineamento experimental ................. 20

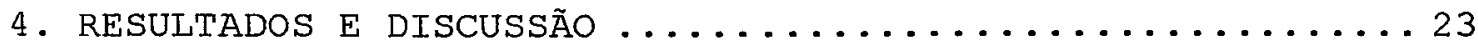

4.1. Desenvolvimento e rendimento agrícola em presença de calcário .......................... 23

4.1.1. Indice de velocidade de emergência.......23

4.1.2. População inicial................. 23

4.1.3. População final .................... 24

4.1.4. Número total de vagens por metro.........24

4.1.5. Número de vagens comerciais por metro...... 25

4.1.6. Massa total de vagens por metro.......... 26

4.1.7. Massa de vagens comerciais por metro......26

4.1.8. Número total de vagens por planta ........ 27

4.1.9. Número de vagens comerciais por planta..... 27

4.1.10. Massa total de vagens por planta........28

4.1.11. Massa de vagens comerciais por planta.....28

4.1.12. Número total de grãos por metro......... 29

4.1.13. Número de grãos comerciais por metro ...... 29

4.1.14. Massa total de grãos por metro.......... 30

4.1.15. Massa de grãos comerciais por metro....... 31

4.1.16. Número total de grãos por planta........ 31

4.1.17. Número de grãos comerciais por planta .... 31

4.1.18. Massa total de grãos por planta......... 32

4.1.19. Massa de grãos comerciais por planta...... 32

4.1.20. Rendimento total de grãos comerciais por vagem ............................ 32

4.1.21. Rendimento agrícola ................ 33

4.1.22. Considerações gerais ................ 33

4.2. Desenvolvimento e rendimento agrícola em ausência de calcário ........................... 43

4.2.1. Indice de velocidade de emergência....... 43

4.2 .2 . População inicial ................. 43

4.2.3. População final .................... 44

4.2.4. Número total de vagens por metro.........44 44

4.2.5. Número de vagens comerciais por metro ......44 44

4.2.6. Massa total de vagens por metro......... 45 
4.2.7. Massa de vagens comerciais por metro....... 45

4.2.8. Número total de vagens por planta........ 45

4.2.9. Número de vagens comerciais por planta ..... 46

4.2.10. Massa total de vagens por planta........ 46

4.2.11. Massa de vagens comerciais por planta .... 47

4.2.12. Número total de grãos por metro........4 47

4.2.13. Número de grãos comerciais por metro ..... 47

4.2.14. Massa total de grãos por metro..........48

4.2.15. Massa de grãos comerciais por metro ......4 48

4.2.16. Número total de grãos por planta ........ 48

4.2.17. Número de grãos comerciais por planta ....48

4.2.18. Massa total de grãos por planta.........49 49

4.2.19. Massa de grãos comerciais por planta......49

4.2.20. Rendimento total de grãos comerciais por vagem ............................ 49

4.2 .21 . Rendimento agrícola ............... 50

4.2.22. Considerações gerais ............... 50

4.3. Análises químicas do solo ...................60

4.3.1. Experimento em presença de calcário.......60

4.3.2. Experimento em ausência de calcário.......61

4.4. Análises foliares ..................... 62

4.5. Clima e crescimento das plantas ..............63

5. CONCLUSÕES .......................... 81

ANEXOS .............................. 82

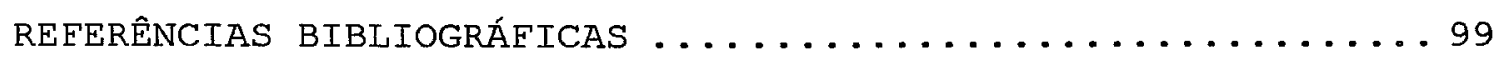




\title{
COMPONENTES DA PRODUÇÃO E DO RENDIMENTO DE AMENDOIM (Arachis hypogaea L.) SUBMETIDO À CAIAGEM E A DIFERENTES DOSES DE GESSO AGRÍCOLA, COMBINADOS A ÉPOCAS E MODOS DE APLICAÇÃO
}

\author{
Autor: RODRIGO EGÉA DE MIRANDA
} Orientador: PROF. DR. GIL MIGUEL DE SOUSA CÂMARA

\section{RESUMO}

- presente estudo foi conduzido a campo, durante 15 meses em área da Fazenda Sertãozinho pertencente a ESALQ/USP, no município de Piracicaba, Estado de são Paulo. 0 solo da referida área é definido como sendo um Latossolo Vermelho-amarelo, textura média (LE).

Foram realizadas análises químicas de macro e micronutrientes do solo. Com base nos resultados, foi realizada calagem em metade da área, visando-se elevar a saturação por bases. a 70\%. Foi feita incorporação do corretivo através de arado e grade niveladora. A área ficou em pousio por 40 dias.

A distribuição das parcelas deu-se em blocos casualizados com 3 repetições, para ambos os experimentos (com e sem aplicação de calcário). Para a cultivo 'da seca', não foi realizado novo preparo do solo, apenas sulcou-se novamente as parcelas para realizar a nova semeadura.

Foi feita a adubação normal de semeadura a base de fósforo e potássio em todas as parcelas experimentais, exceto as parcelas correspondentes ao tratamento sem nenhuma adubação, nos cultivos 'das águas' e 'da seca'.

- gesso agrícola foi aplicado somente no cultivo 'das águas', em todas as combinações entre doses (400, 
$800,1200 \mathrm{~kg} / \mathrm{ha}$ ), épocas (semeadura e florescimento) e modos de aplicação (área total e localizado), totalizando 12 tratamentos. Foram inseridos 4 tratamentos complementares que representam a dose zero de gesso agrícola: dois com adubação de plantio utilizando duas diferentes fontes de fósforo; um com aplicação de enxofre elementar (somente no cultivo 'das águas') e um sem aplicação de adubo.

Foi semeado o cultivar Tatu que, de acordo com a bibliografia, é mais sensivel à deficiência de cálcio. os tratos culturais foram os habituais para a cultura.

Foram avaliadas todas as combinações entre gesso agrícola, épocas e modos de aplicação, assim como diferentes adubações de plantio em presença ou não de calagem, através de determinações de emergência a campo, análise de solo e folha, componentes da produção e do rendimento.

Como resultados, considerando-se o conjunto das características avaliadas, obteve-se um efeito positivo da adubação de plantio principalmente no cultivo 'da seca', assim como um efeito depressivo do uso do enxofre elementar no plantio, em todas as situações. Houve efeito residual positivo do gesso agrícola no cultivo 'da seca'. Não houve diferença entre os locais de aplicação do gesso agrícola, mas em presença de calcário, a aplicação deste, por ocasião do florescimento, mostrou-se melhor que a aplicação na semeadura (em ambos os cultivos). Este fato não foi verificado em ausência de calcário. 


\section{PRODUCTION AND YIELD COMPONENTS OF PEANUT \\ (Arachis hypogaea L.) SUBMITTED TO LIMING AND DIFEERENT LEVELS OF PHOSPHOGYPSUM, COMBINED WITH PERIODS AND APPLICATION AREAS}

Author: RODRIGO EGÉA DE MIRANDA Adviser: PROE. DR. GIL MIGUEL DE SOUSA CÂMARA

SUMMARY

The present research was carried out on a Sertãozinho Farm field of ESALQ/USP, in the Piracicaba district of São Paulo state, during 15 months. The soil is classified as a Red-yellow Latossol, medium texture (LE).

Macro and micronutrient chemical analyses of the soil were done. Liming was done on half of the area, expecting to elevate the bases saturation to $70 \%$ and incorporated by ploughing and harrowing, and left unsown for 40 days.

The blocks were constituted of randomized plots with three replications, for both trials (with and without liming). No-till to the winter crop was performed, only the seed beds were prepared for a new sowing.

Usual levels of phosphorus and potassium were applied on the whole trials as sowing fertilization, except in the plots of the treatment without any fertilizer application, in winter and summer crops.

Phosphogypsum was applied to the summer crop (only), in all combinations between levels (400, 800, 1200 $\mathrm{kg} / \mathrm{ha}$ ), application periods (sowing and flowering) and placement (total area and localized), in 12 treatments. Four complementary treatments were added to represent the absence of 
phosphogypsum: two with sowing fertilization using different sources of phosphorus; one with elementary sulphur applied on summer crop (only) and one without fertilizer.

Tatu cultivar was chosen because its higher sensible to calcium deficiency, according to the literature. Crop management was as usual.

All the combinations with phosphogypsum, periods and application areas as well as different sowing fertilization, with or without liming were evaluated by the seed emergence, soil and leaf analyses, production and yield components.

Considering the studied variables as a whole, the results showed a positive effect of the sowing fertilization mainly on winter crop and a depressive effect on elementary sulphur by sowing, in all situations. Phosphogypsum had a positive residual effect on winter crop. There was no difference between phosphogypsum placements, but its use at flowering, in the limestone presence, was better than when it was used at sowing (in winter and summer crops). This fact was not verified in the absence of limestone. 
1. INTRODUÇÃO

Atualmente, o Estado de São Paulo constitui-se no principal produtor nacional de amendoim, com rendimento agrícola médio da ordem de $1.900 \mathrm{~kg} / \mathrm{ha}$, com volume global de produção de $154 \mathrm{mil}$ toneladas, assentada numa área de aproximadamente $80 \mathrm{mil}$ hectares (FUNDAÇÃO INSTITUTO BRASILEIRO DE GEOGRAFIA E ESTATÍSTICA-FIBGE, 1996).

Comparando-se com a produção brasileira, o Estado de São Paulo representa 89,3응 da produção nacional, correspondente a $84,3 \frac{0}{0}$ da área total brasileira cultivada com essa leguminosa (FIBGE, 1996).

Devido a sucessivos anos de baixa remuneração do produtor de amendoim, a área de produção diminuiu drasticamente durante a década de oitenta. A dificuldade de colheita, os problemas gerados pela aflatoxina e o cultivo de soja, também têm colaborado para o decréscimo da área cultivada.

Paralelamente ao mercado tradicional de óleo de amendoim, produzido por poucas indústrias moageiras, ao longo dos anos 80, cresceu o mercado de amendoim para a indústria de confeitos (alimentícias), que proporciona melhor remuneração aos agricultores, exigindo em contrapartida, produto de melhor aspecto e qualidade, principalmente quanto à presença de aflatoxina. Como resultado de tais desestímulos por parte do mercado de óleo e exigências por parte da indústria alimentícia, houve decréscimo na área cultivada, porém, 
associada a uma certa seleção de produtores, de maneira que hoje, aparentemente, bons agricultores produzem amendoim.

A produção paulista atual assenta-se em duas áreas distintas: a) áreas de reforma canavieira, com diferentes tipos de solo quanto à fertilidade; b) áreas de reforma de pastagens, geralmente constituídas por solos de baixa fertilidade e exauridos em sua fertilidade natural.

Nas áreas de reforma canavieira (Região de Ribeirão Preto), normalmente é feita a correção (calagem) e preparo do solo para a cana-de-açúcar, arrendando-se a terra para produtores de amendoim, que a cultivam com essa leguminosa entre os meses de setembro/outubro e janeiro/fevereiro, denominado "amendoim das águas", liberando a área para o plantio da cana-de-ano-e-meio. Nestas áreas encontram-se diversas situações de manejo de solo, relacionadas principalmente ao manejo dado às últimas soqueiras de cana-deaçúcar, de modo que, o amendoim pode ser semeado desde em solos que não recebem nenhum tipo de correção, até em solos enriquecidos com vinhaça.

Nas áreas de reforma de pastagens (Região de Marília), também ocorrem diferentes situações quanto aos cuidados necessários para se manter a fertilidade dos solos. Normalmente não é comum o uso de calagem, sendo que o produtor de amendoim faz apenas a adubação de semeadura, raramente fundamentada em análise química de solo. Nestas áreas é comum o cultivo do "amendoim das águas" (set/out - jan/fev) seguido do "amendoim da seca" (jan/fev - mai/jul).

Associadas às diferentes áreas de manejo da cultura, encontram-se diferentes tipos de produtores, desde os mais eficientes até os mais negligentes, situando-se entre extremos, aqueles que possuem dúvidas quanto a melhor maneira de adubar e conduzir a cultura.

Ultimamente, tais dúvidas tem se agravado em função da recomendação de aplicação de gesso agrícola como fonte de cálcio e enxofre para amendoim, tanto em áreas de 
reforma canavieira como em áreas de reforma de pastagens, sendo que alguns produtores têm demonstrado resistência ao uso de gesso agrícola, devido a uma possível lixiviação de potássio ao longo do perfil do solo.

Muitas destas recomendações fundamentam-se em poucos trabalhos de pesquisa consistentes, que levaram somente em consideração o rendimento agrícola final, sem se preocuparem com outras características do solo (ao longo do tempo), além da própria planta. Em casos extremos, há quem preconize o uso isolado do gesso agrícola em detrimento dos benefícios da calagem, fundamentados em trabalhos que têm demonstrado melhores respostas ao gesso agrícola do que ao calcário. Neste aspecto, deve-se considerar que há excesso de gesso agrícola em algumas indústrias de fertilizantes fosfatados, ao mesmo tempo em que se encontra em andamento no Estado de São Paulo, um programa de incentivo à utilização do calcário.

Apesar desses atuais problemas, há perspectivas favoráveis ao crescimento da área cultivada com essa leguminosa, como respostas ao mercado francamente remunerador para o amendoim do tipo confeito (indústria alimentícia). Assim, é de grande importância e necessidade, o desenvolvimento de pesquisas com a finalidade de solucionar os diversos problemas que envolvem a cultura, tanto em relação a produtividade, quanto em relação a qualidade do produto, com objetivo de alcançar altas produções de grãos de elevada qualidade.

Dessa forma, o presente trabalho de pesquisa, visou estudar os efeitos de níveis crescentes de gesso agrícola, associados a épocas e modos de aplicação, além de adubações de plantio, em ausência e presença de calagem, sobre componentes da produção e o rendimento agrícola de amendoim. 


\section{REVISÃO DE LITERATURA}

Godoy et al. (1992) em revisão à literatura pertinente ao assunto, citam que o amendoim é tido como uma cultura tolerante a fatores que normalmente tornam os solos ácidos e inférteis, além de ser tolerante à toxidez de manganês e de alumínio. Embora, afirma que a disponibilidade de cálcio na solução do solo, principalmente na zona de frutificação (primeiros $10 \mathrm{~cm}$ de profundidade), é importante para uma boa produção de amendoim. Este mesmo autor afirma que o cálcio é um importante componente da parede celular e influi na rigidez dos tecidos vegetais. Desta forma, está associado a resistência dos tecidos à penetração de fungos e ao fluxo de íons. Da mesma forma, Smith et al. (1994) ratifica a importância do cálcio como componente da lamela média das células e sua influência na permeabilidade das membranas. Afirma ainda, que este é responsável pela elongação e divisão celular.

Ambas citações relatam a restrita mobilidade do cálcio no floema, sendo assim, a deficiência deste nutriente ocorre em tecidos jovens.

Sichmann (1966) afirma que o cálcio proporciona vagens firmes e bem granadas. Sellescop (1973) verificou efeito benéfico do cálcio sobre as vagens e o desenvolvimento do caule do amendoim. Cita também, que um excesso de cálcio, causado por aplicações excessivas de calcário, pode ser prejudicial. Malavolta (1980) em publicação sobre Nutrição Mineral de Plantas, afirma que o cálcio até certo nível estimula a absorção de potássio. Afirma ainda, que o cálcio é 
indispensável para manter a estrutura e o funcionamento normal das membranas, particularmente a do plasmalema, além de ser muito importante para o desenvolvimento dos ginóforos.

Godoy et al. (s.d.) citam que o cálcio exerce influência positiva na quantidade e qualidade de frutos produzidos. Absorvido por raízes, ginóforos e casca dos frutos em formação, a deficiência causa redução na fertilidade de flores, no número de ginóforos formados e aumento no número de vagens chochas com casca frágil. Em relação ao enxofre, citam que este se concentra principalmente nos frutos; tem a função de ativar e prolongar o florescimento, além de interferir na absorção de nitrogênio, pois afeta a nodulação.

Lasca (1987) avaliando a nutrição cálcica do amendoim no estado de são Paulo, realça a importância desse nutriente para a formação de vagens, sendo que seu baixo teor nos solos de cultivo causa vagens chochas, podendo resultar em até $80 \%$ de redução de produção. Na parte vegetativa, Godoy et al. (1992) citam como sintomas de deficiência, a presença de manchas que assemelham-se às de cercospora com posterior senescência das mesmas, além da alta porcentagem de flores inférteis. $\mathrm{Na}$ parte produtiva, citam $\circ$ abortamento e murchamento de grãos, além do chochamento de vagens como os efeitos da deficiência deste nutriente. Smith et al. (1994) ratificam estes sintomas e citam que em deficiência mais severa, pode ocorrer redução no número e tamanho das raízes, redução na elongação das hastes (plantas anãs) e das folhas, além de morte da gema apical.

Rodrigues Filho et al. (1986), trabalhando em solução nutritiva com vários tratamentos relativos à omissão de macronutrientes em amendoim, cultivar Tatu, verificaram que os nutrientes que mais reduziram a altura de planta e a formação de matéria seca na parte aérea foram $\mathrm{N}$, Ca e Mg. Porém, não estudaram os efeitos dos tratamentos sobre a reprodução do amendoim. Sichmann et al. (1967) afirmam que o cálcio é 
absorvido em grande quantidade após o florescimento. o motivo pelo qual a disponibilidade de ca na zona de frutificação deve ser alta, foi citada por Malavolta et al. (1967). Estes autores verificaram que apenas 13응 do elemento absorvido pelo sistema radicular chega aos frutos, mas quando absorvido pelos ginóforos, 90용 chega a estes.

Sichmann (1968) afirma que o suprimento de cálcio não deve ser limitado à correção de acidez do solo, sendo que deve haver boa disponibilidade deste na zona de frutificação, pois a translocação de $\mathrm{Ca}$ das raízes para as vagens é muito lenta. Skelton \& Shear (1971) trabalhando com plantas de amendoim em recipientes diferenciados para desenvolvimento de raízes e de vagens, constataram que o Ca absorvido pelas raízes não é translocado e nem redistribuído para os frutos, devido à sua imobilidade na planta e à dependência da corrente transpiratória para o seu movimento no xilema. Também verificaram que a deficiência de Ca na zona de frutificação causa morte de ginóforos, redução no número de sementes por vagem e no número de vagens bi-segmentadas.

Godoy et al. (1992), afirmam que muitas vezes a calagem não tem efeito positivo sobre a produção, a não ser que esteja associada à correção de deficiência de cálcio do solo. Afirmam ainda, que a aplicação via foliar não reduz os efeitos da deficiência sobre a produção. Nakagawa et al. (1966) trabalhando com calagem e adubação, não notaram efeito do cálcio de forma significativa sobre a produção. Do mesmo modo, Sichmann (1966) afirma que nem sempre a resposta à calagem é significativa. Cita como outras fontes de Ca, o gesso agrícola ou o superfosfato simples (fonte de fósforo, cálcio e enxofre).

Quaggio et al. (1982) citam que tanto o calcário como o gesso agrícola podem fornecer ca. o calcário deve ser aplicado em dose mais elevada que o normal, em área total antes da semeadura; o gesso agrícola pode ser aplicado em pequenas doses, localizado, no florescimento; ou, pouco antes 
da semeadura, em doses mais elevadas, em área total. Godoy et al. (s.d.) salientam que o modo de aplicação (localizado ou em área total) é muito importante, pois a absorção se dá pelo ginóforo para efeito de frutificação. Citam como fontes de cálcio os calcários calcítico e dolomitico, além do gesso agrícola.

Segundo Vitti (1986), ○ gesso agrícola tem dupla função: além de servir como fonte de $\mathrm{Ca}$ e de $\mathrm{S}$ para as culturas, ao mesmo tempo neutraliza o excesso de alumínio tóxico de subsuperfície e enriquece em cálcio as camadas mais profundas do solo, permitindo maior desenvolvimento do sistema radicular, resultando em maior resistência à seca e maior aproveitamento dos nutrientes do solo e dos adubos aplicados. Baseado em diversos trabalhos de pesquisa, recomenda $500 \mathrm{~kg} / \mathrm{ha}$ de gesso agrícola para solos arenosos, 500 a $1.000 \mathrm{~kg} / \mathrm{ha}$ para solos de textura média e 1.000 a $1.500 \mathrm{~kg} / \mathrm{ha}$ para solos argilosos.

Godoy et al. (1992) citam o calcário e o gesso agrícola como as principais fontes de cálcio para o amendoim. Citam também, que as respostas à calagem são diversas e podem estar associadas à forma de aplicação e à solubilidade do calcário. Afirmam ainda, que o gesso agrícola leva vantagem sobre o calcário, pois é bem solúvel, mas em solos arenosos e sob chuvas pesadas, ele pode ser levado para baixo da zona de frutificação o que não ocorre com o calcário, que permanece na profundidade que foi incorporado. Citam ainda, que a calagem não tem apenas a função de fornecer cálcio, mas também de elevar a disponibilidade de outros nutrientes, tal como o boro. Seguindo a mesma linha, Smith et al. (1994), afirmam que devese usar o gesso agrícola quando $\circ \mathrm{pH}$ do solo estiver no nível desejado e houver a necessidade de fornecimento de cálcio adicional. Sugerem a aplicação a lanço, em área total, no início do florescimento.

$\mathrm{Da}$ mesma forma que skelton \& Shear (1971), Velásquez et al. (1987) trabalharam em dois diferentes 
recipientes de crescimento: para raízes e para vagens. Em relação a calcário e a gesso agrícola em solução nutritiva, não observaram efeito sobre $\circ$ número e o peso de vagens, mas notaram 50\% de aumento no número e peso de grãos, tanto para uma como para outra fonte.

Fornasieri et al. (1987) verificaram que mesmo fazendo-se calagem, gessagem ou ambas, a aplicação em cobertura de cálcio no florescimento gera efeito positivo sobre o número de grãos normais e o número potencial de grãos/vagem. Não houve resposta para peso de 1.000 grãos.

Segundo Gallo (1987), a cultura do amendoim apresenta dois períodos criticos em termos nutricionais: 0 primeiro ocorre no florescimento, com aumento do metabolismo da planta, quando ocorre também o aumento dos teores de $\mathrm{N}, \mathrm{P}$ e Ca na mesma; o segundo acontece durante a penetração dos ginóforos no solo, quando estes apresentam alta capacidade de absorção de nutrientes, os quais devem estar disponíveis na área de penetração.

De acordo com Sichmann et al. (1967), a planta de amendoim extrai $72 \mathrm{~kg}$ de $\mathrm{Ca}$ e $15 \mathrm{~kg}$ de $\mathrm{S}$ por tonelada de vagens produzidas, mas se a parte aérea permanecer no campo, os valores exportados são de 3 e $5 \mathrm{~kg}$ por tonelada de vagens, respectivamente.

Coelho \& Tella (1967), observaram a curva de absorção de macronutrientes pela planta de amendoim e constataram que, para qualquer um deles, a absorção é bem maior após o florescimento. Para o cálcio, a absorção ocorre entre 35 e 80 dias após a emergência e para o enxofre, entre 50 e 80 dias.

Sichmann et al. (1970), estudando a acumulação de macronutrientes por planta de amendoim, verificaram extração de $142 \mathrm{~kg}$ de $\mathrm{N}, 15 \mathrm{~kg}$ de $\mathrm{P}, 30 \mathrm{~kg}$ de $\mathrm{K}, 5 \mathrm{~kg}$ de $\mathrm{Ca}, 10 \mathrm{~kg}$ de $\mathrm{Mg}$ e $7,5 \mathrm{~kg}$ de $\mathrm{S}$ pela produção de vagens e $201 \mathrm{~kg}$ de $\mathrm{N}, 16 \mathrm{~kg}$ de $\mathrm{P}, 140 \mathrm{~kg}$ de $\mathrm{K}, 113 \mathrm{~kg}$ de $\mathrm{Ca}, 20 \mathrm{~kg}$ de $\mathrm{Mg}$ e $16 \mathrm{~kg}$ de $\mathrm{S}$ pela 
parte vegetativa. No tocante a $\mathrm{Ca}$ e $\mathrm{S}$ nas vagens, verificaram que 60 응 do $\mathrm{Ca}$ e $75 \%$ do $\mathrm{S}$ se encontravam na semente.

Malavolta (1980) afirma que em valores baixos de $\mathrm{pH}$, doses crescentes de cálcio estimulam o acréscimo de matéria seca de raiz e parte aérea. Já em valores de pH próximos à neutralidade, com poucos ppm de Ca atinge-se a máxima acumulação de matéria seca.

$$
\text { Neptune et al. (1982 e 1983), realizaram }
$$

diversos experimentos com os cultivares Tatu e Tatuí, concluindo que, quando houve resposta positiva à calagem prévia ou na semeadura, esta ocorreu para o cultivar Tatu.

Quaggio et al. (1982) também verificaram ser o cultivar Tatu o mais sensível à deficiência de cálcio, dentre os utilizados no estado de São Paulo. Obtiveram resposta positiva até os valores de $1,5 \mathrm{meq} / 100 \mathrm{~cm}^{3}$ ou $40 \%$ de saturação de bases, no solo. Acima destes valores não houve resposta. Estes valores contrastam com outros dados existentes e citados pelos mesmos.

Godoy et al. (1992) afirmam que existe uma tendência dos cultivares de grãos maiores em serem mais exigentes em cálcio. Afirmam também, assim como smith et al. (1994), serem os cultivares do grupo Virgínia os mais exigentes em disponibilidade de cálcio na zona de frutificação, seguidos dos cultivares do grupo valência (Tatu) e pelos do grupo Spanish (Tatuí).

Segundo Guilherme (1986), $30 \mathrm{~kg} / \mathrm{ha}$ de $\mathrm{S}$ é 0 suficiente para promover a máxima produção de boa parte das culturas (anuais e perenes). Isto corresponderia a uma dose de $200 \mathrm{~kg} / \mathrm{ha}$ de gesso agrícola. Não cita se este enxofre pode ser proveniente de qualquer fonte. Segundo Godoy et al. (1992), a aplicação de sulfato de potássio ou de sulfato de magnésio, favoreceu a incidência de podridões de vagens e a aplicação de enxofre na forma de sulfato de cálcio (gesso agrícola), 
minimizou os efeitos da aplicação dos dois primeiros. Este fato foi confirmado por outro trabalho citado pelos mesmos autores. Gallo (1987), trabalhando em solos com teores de $\mathrm{Ca}$ de 0,83 e 3,97 meq/100 $\mathrm{cm}^{3}$ obteve resposta positiva em produção de vagens e qualidade de grãos, apenas para o teor de $0,83 \mathrm{meq} / 100 \mathrm{~cm}^{3}$ de Ca no solo, através da aplicação de gesso agrícola em cobertura. Nestes ensaios, não foi realizada a calagem antes da instalação dos mesmos, impossibilitando a avaliação do efeito desta sobre a resposta a gesso agrícola.

Godoy et al. (1992), afirmam que as respostas a cálcio são maiores quando se avalia a produção de forma qualitativa (tamanho de grãos, teor de óleo, presença de aflatoxina, etc), principalmente para os cultivares utilizados em nosso país. 


\section{MATERIAL E MÉTODOS}

\subsection{Local e época}

- presente trabalho foi desenvolvido em área experimental da Fazenda Sertãozinho, pertencente a ESALQ/USP, em Piracicaba, São Paulo, localizada geograficamente a $22^{0} 42^{\prime}$ 30 ' de latitude SuI, $47^{\circ} 38^{\prime} 00^{\prime}$ ' de longitude Oeste e $580 \mathrm{~m}$ de altitude, aproximadamente.

A pesquisa, em condições de campo, foi conduzida durante o período compreendido entre a segunda quinzena do mês de setembro de 1992 (época da realização da análise do solo) e dezembro de 1993. Foram feitos dois cultivos: 'das águas' e 'da seca'. O amendoim 'das águas' foi semeado em 11/11/92 e colhido em 02/03/93, correspondendo a 111 dias de ciclo vegetativo. O amendoim 'da seca' foi semeado em 23/03/93 e colhido em 27/07/93, correspondendo a 126 dias de ciclo vegetativo.

\subsection{Solo}

- experimento foi instalado em solo classificado como Latossolo Vermelho-Amarelo, textura média (LE), anteriormente cultivado com milho e submetido a pousio durante $\circ$ ano agrícola precedente a condução do experimento. Este solo é representativo em relação aos solos tradicionais da cultura no Estado de são Paulo. Pela análise de solo, apresentada na Tabela 1, pode-se observar que este solo é adequado à realização do presente estudo. 
Tabela 1. Análise química do solo da área experimental antes da sua correção

\begin{tabular}{|c|c|c|c|c|c|c|c|c|c|c|}
\hline \multirow{2}{*}{$\begin{array}{l}\text { Prof. } \\
\mathrm{cm}\end{array}$} & \multirow{2}{*}{$\begin{array}{l}\mathrm{M} . \mathrm{O} \\
\mathrm{g} / \mathrm{dm}^{3}\end{array}$} & \multirow{2}{*}{$\begin{array}{c}\mathrm{pH} \\
\mathrm{CaCl}_{2}\end{array}$} & \multirow{2}{*}{$\begin{array}{l}\mathrm{P} \text { res } \\
\mathrm{mg} / \mathrm{dm}^{3}\end{array}$} & $\bar{K}$ & $\mathrm{Ca}$ & $\mathrm{Mg}$ & $\mathrm{H}+\mathrm{Al}$ & $\bar{S}$ & $\bar{T}$ & \multirow{2}{*}{$\begin{array}{l}\mathrm{V} \\
ㅇ\end{array}$} \\
\hline & & & & \multicolumn{6}{|c|}{$\mathrm{mmol}_{\mathrm{c}} / \mathrm{dm}^{3}$} & \\
\hline $0-20^{1}$ & 27,8 & 4,45 & 6,2 & 1,0 & 7,2 & 3,4 & 36,1 & 12,0 & 48,0 & 24,3 \\
\hline $20-40^{2}$ & 25,4 & 4,40 & 4,3 & 0,5 & 6,3 & 2,8 & 36,1 & 10,0 & 46,0 & 21,0 \\
\hline $0-20^{3}$ & 29,4 & 4,40 & 8,2 & 1,2 & 2,2 & 2,9 & 38,1 & 6,0 & 44,0 & 14,2 \\
\hline $20-40^{4}$ & 27,0 & 4,35 & 5,4 & 0,9 & 5,4 & 3,1 & 36,1 & 9,0 & 46,0 & 20,7 \\
\hline
\end{tabular}

\subsection{Cultivar}

Utilizou-se o cultivar de amendoim Tatu, cujo ciclo de maturação é precoce. A escolha deste material genético baseou-se na sua maior suscetibilidade à deficiência de cálcio e pelo fato de ser utilizado em aproximadamente 95\% da área cultivada no Brasil.

\subsection{Instalação dos experimentos}

Foram instalados dois experimentos; um com calcário (Experimento I) e outro sem calcário (Experimento II), sendo a dosagem de calcário calculada para elevar a saturação por bases a $70 \%(3,4$ t/ha de calcário dolomítico PRNT=65\%). Em seguida, o solo foi preparado através de aração $(0$ a $0,30 \mathrm{~m}) \mathrm{e}$ gradagem para nivelamento do mesmo.

o solo permaneceu em pousio por aproximadamente 40 dias, quando então aplicou-se o herbicida trifluralin à dosagem de 1,0 litro por hectare em pré-semeadura incorporado ao solo.

As parcelas experimentais foram demarcadas após a abertura mecanizada dos sulcos de semeadura. Todas as parcelas receberam adubação fosfatada na dose de $80 \mathrm{~kg} / \mathrm{ha}$ de $\mathrm{P}_{2} \mathrm{O}_{5}$ e potássica na dose de $30 \mathrm{~kg} / \mathrm{ha}$ de $\mathrm{K}_{2} \mathrm{O}$ na semeadura de 
ambos os cultivos, com exceção do tratamento controle total, que não recebeu qualquer adubação, em nenhum dos dois cultivos. Como fonte de potássio foi utilizado o cloreto de potássio e como fonte de fósforo foi utilizado o superfosfato triplo (apenas as parcelas do tratamento CSSK foram adubadas com superfosfato simples, ao invés do superfosfato triplo). Esta adubação foi dimensionada de acordo com a análise química do solo e localizada no fundo dos sulcos em mistura com o mesmo.

Sementes certificadas do cultivar Tatu, já tratadas com fungicida, foram semeadas nos sulcos previamente adubados e cobertas com aproximadamente $0,03 \mathrm{~m}$ de terra. $\mathrm{A}$ densidade de semeadura foi de 20 sementes por metro e o espaçamento entre linhas de $0,50 \mathrm{~m}$.

\subsection{Tratamentos}

Foram conduzidos dois experimentos de campo, correspondentes a duas áreas experimentais, sendo uma com calagem (Experimentó I) e outra sem calagem (Experimento II). Em cada experimento foram aplicados os seguintes tratamentos:

Tratamentos Complementares (sem aplicação de gesso agrícola) :

$\mathrm{T} 1$ = GSI - adubação fosfatada de plantio, à base de superfosfato triplo e adubação potássica. Aplicação localizada (no sulco) de enxofre ao nível de $40 \mathrm{Kg} / \mathrm{ha}$ na semeadura do cultivo 'das águas' (somente).

T2 = CPK - adubação fosfatada de plantio, à base de superfosfato triplo e adubação potássica.

T3 = CSSK - adubação fosfatada de plantio, à base de superfosfato simples e adubação potássica.

T4 = CT - sem aplicação de fósforo, potássio e enxofre.

Tratamentos com gesso agrícola:

Todos estes tratamentos receberam adubação 
fosfatada à base de superfosfato triplo e adubação potássica. $\mathrm{T} 5=\mathrm{G} 1 \mathrm{SL}-400 \mathrm{Kg} / \mathrm{ha}$ de gesso agrícola, aplicado na semeadura de forma localizada nos sulcos. $\mathrm{T} 6=\mathrm{G} 1 \mathrm{FL}-400 \mathrm{Kg} / \mathrm{ha}$ de gesso agrícola, aplicado no início do florescimento de forma localizada lateralmente às linhas.

$\mathrm{T} 7=$ GISAT $-400 \mathrm{Kg} / \mathrm{ha}$ de gesso agrícola, aplicado na semeadura em área total (em cobertura pós-plantio) . $\mathrm{T} 8=\mathrm{G} 1 \mathrm{EAT}-400 \mathrm{Kg} / \mathrm{ha}$ de gesso agrícola, aplicado no início do florescimento em área total (em cobertura).

$$
\mathrm{T9}=\mathrm{G} 2 \mathrm{SL}-800 \mathrm{Kg} / \mathrm{ha} \text { de gesso agrícola, }
$$
aplicado na semeadura de forma localizada nos sulcos.

$\mathrm{T} 10=\mathrm{G} 2 \mathrm{FL}-800 \mathrm{~kg} / \mathrm{ha}$ de gesso agricola, aplicado no início do florescimento de forma localizada lateralmente às linhas.

$\mathrm{T} 11=\mathrm{G} 2 \mathrm{SAT}-800 \mathrm{Kg} / \mathrm{ha}$ de gesso agrícola, aplicado na semeadura em área total (em cobertura pós-plantio). $\mathrm{T} 12=\mathrm{G} 2 \mathrm{FAT}-800 \mathrm{Kg} / \mathrm{ha}$ de gesso agrícola, aplicado no início do florescimento em área total (em cobertura).

$\mathrm{T} 13=\mathrm{G} 3 \mathrm{SL}-1.200 \mathrm{Kg} / \mathrm{ha}$ de gesso agrícola, aplicado na semeadura de forma localizada (nos sulcos).

$\mathrm{T} 14=\mathrm{G} 3 \mathrm{FL}-1.200 \mathrm{Kg} / \mathrm{ha}$ de gesso agrícola, aplicado no início do florescimento de forma localizada lateralmente às linhas.

T15 = G3SAT - $1.200 \mathrm{Kg} / \mathrm{ha}$ de gesso agrícola, aplicado na semeadura em área total (em cobertura pós-plantio). T16 = G3FAT - $1.200 \mathrm{Kg} / \mathrm{ha}$ de gesso agrícola, aplicado no início do florescimento em área total (em cobertura). 
Quadro 1. Descrição esquemática dos tratamentos

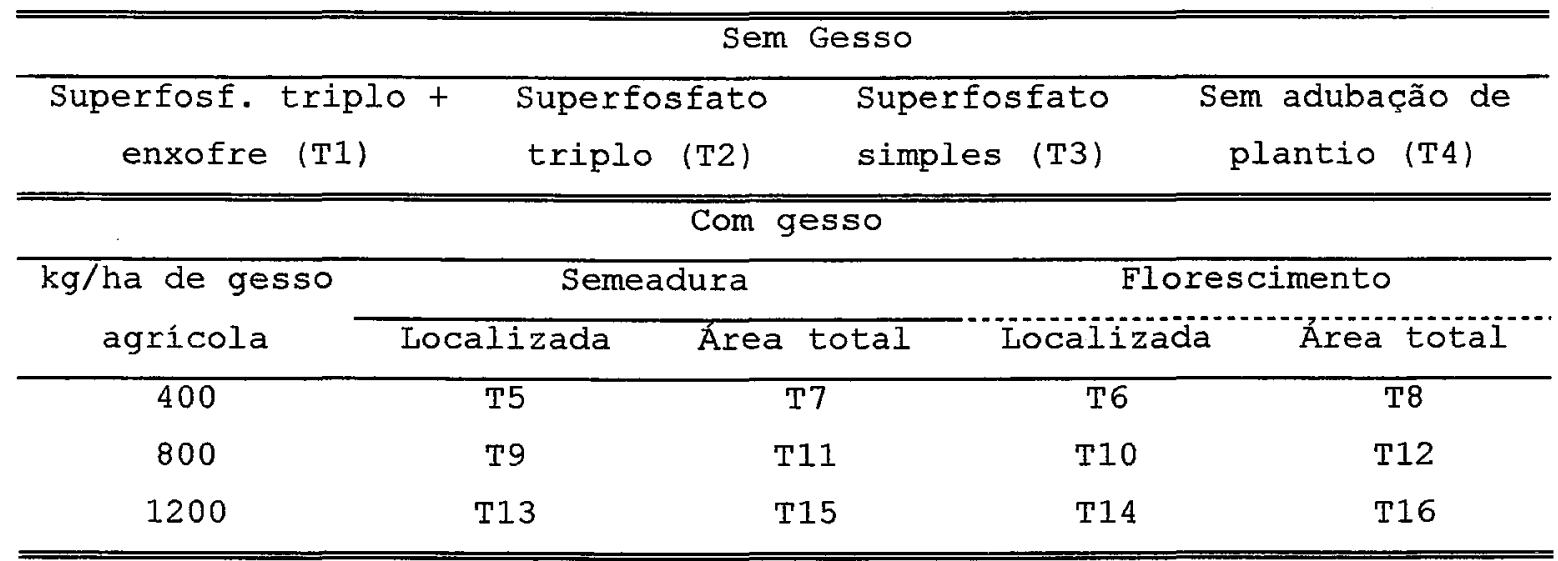

A aplicação de enxofre conforme explicitado no tratamento GSL, teve por objetivo compensar o efeito do enxofre contido no gesso agrícola, para melhor determinação do provável efeito isolado do cálcio. o enxofre foi aplicado apenas na semeadura do cultivo 'das águas', pois segundo RAIJ' se aplicado no florescimento não estaria disponível na época de maior necessidade pela planta.

Houve dois tratamentos complementares com apenas fósforo e potássio. O primeiro, denominado CPK, recebeu a mesma fonte de fósforo que os tratamentos com aplicação de gesso agrícola (Superfosfato triplo). o outro, denominado CSSK, recebeu fósforo via superfosfato simples, visando-se a comparação de desempenho da cultura, sob diferentes fontes de fósforo.

Nos dois experimentos foram utilizadas parcelas experimentais constituídas por 8 linhas com espaçamento de $0,50 \mathrm{~m}$ entre elas. Cada Iinha lateral constituiu-se em bordadura portanto, as 6 linhas centrais representaram a área útil de cada parcela. Também para efeito de bordadura entre parcelas dentro de blocos, foi respeitada

${ }^{1}$ RAIJ, B. van (Pesquisador Científico da seção de Fertilidade do Solo - IAC). Orientação pessoal, 1992. 
uma distância de $0,50 \mathrm{~m}$. Cada linha teve $4,0 \mathrm{~m}$ de comprimento 0 que configurou parcela de $16 \mathrm{~m}^{2}$.

\subsection{Condução do experimento}

- controle de plantas daninhas foi efetuado, quando necessário, através da aplicação de herbicidas ou capinas manuais, de acordo com a situação e época.

O controle de pragas e doenças foi feito sistematicamente, de acordo com os procedimentos normais exigidos pela cultura do amendoim, ou seja, controle químico preventivo, inicialmente para a ocorrência de pragas (tripes e lagarta do pescoço vermelho) e posteriormente para a ocorrência de doenças (cercosporiose). Foi utilizado o inseticida Monocrotophos (Nuvacron - 0,5 1/ha) e o fungicida Propiconazole (Tilt - 0,5 l/ha). Não foi constatado dano severo por pragas ou doenças, em nenhum dos dois cultivos.

\subsection{Características avaliadas}

\subsection{1. Índice de velocidade de emergência}

Foi determinado durante o período de emergência, a partir da data da primeira planta emergida no experimento, diariamente e por parcela, durante 15 dias, através da contagem do número de plantas emergidas em cada dia, em um metro linear previamente definido dentro da parcela útil.

os valores obtidos foram aplicados nas fórmulas descritas a seguir, segundo metodologia descrita por CíCERo et al. (1987), para o cálculo do índice de velocidade de emergência (plantas/dia):

Valor da emergência = Plantas emergidas $\mathrm{x}$ 1

$$
\text { (plantas/dia) }
$$

$$
\text { no dia por }
$$
parcela
Número de dias do teste até o momento 
Índice de velocidade de = Somatória dos valores de emergênemergência (plantas/ dia) cia diários durante a avaliação

\subsubsection{População inicial e final}

Ao final da determinação do indice de velocidade de emergência, foi avaliada a população inicial de plantas, através da contagem do número total de plantas emergidas em todas as linhas úteis de cada parcela. Ao final do ciclo vegetativo, determinou-se a população final, que por facilidade de amostragem, foi determinada em 1,0 metro linear marcado dentro da área útil de cada parcela, como representativo da mesma.

\subsubsection{Análise foliar}

Em função dos tratamentos empregados, a análise foliar das plantas de amendoim foi realizada por ocasião do início da frutificação, amostrando-se o quarto renque formado na haste principal a partir da base do mesmo, desconsiderandose os ramos cotiledonares, segundo Raij (1991).

A determinação dessa característica foi feita em 50 plantas amostrais por tratamento.

\subsubsection{Análise química do solo}

Para monitoramento da evolução da fertilidade do solo em função dos tratamentos empregados, amostras simples de solo foram coletadas em 3 profundidades: 0 a $10 \mathrm{~cm}$; 10 a 20 $\mathrm{cm} ; 20$ a $40 \mathrm{~cm}$. A coleta de amostras em 3 profundidades visou avaliar com maior precisão, os efeitos de tratamentos sobre a fertilidade do perfil superficial do solo.

Através do uso de trado do tipo sonda, foram coletadas 24 amostras simples por tratamento, das quais foi obtida uma amostra composta para efeito de análise química de solo. 
As determinações descritas nos itens 3.7.3. e 3.7.4. foram realizadas ao nivel de tratamento, pois os resultados destas análises são mais importantes para interpretação dos resultados obtidos para outras características agronômicas. Dessa forma não foram analisados estatisticamente, pois nesse caso haveria necessidade de se retirar amostras compostas por parcela experimental, o que resultaria em elevado custo financeiro para a pesquisa.

As determinações descritas a seguir, foram avaliadas com base no total de plantas coletadas em um metro de linha marcado aleatoriamente, por ocasião da semeadura, com a finalidade de precisar melhor, os efeitos dos tratamentos sobre as seguintes caracteristicas:

\subsubsection{Número e massa total de vagens por metro}

Nas plantas amostradas, foi determinado 0 número total de vagens. Então, estas foram pesadas, determinando-se a massa total de vagens por metro.

\subsubsection{Número e massa de vagens comerciais por metro}

Foram consideradas como vagens comerciais, aquelas que possuíam pelo menos 2 grãos bem formados. Em cada metro amostral foi determinada essa característica. Então, estas foram pesadas, determinando-se a massa de vagens comerciais por metro.

\subsubsection{Número e massa total de vagens por planta}

Obtidos pela divisão do número total de vagens por metro pela população final e pela divisão da massa total de vagens por metro pela população final, respectivamente.

3.7.8. Número e massa de vagens comerciais por planta obtidos pela divisão do número de vagens 
comerciais por metro pela população final e pela divisão da massa de vagens comerciais por metro pela população final, respectivamente.

\subsubsection{Número e massa total de grãos por metro}

Após as determinações relativas às vagens, foram efetuadas as avaliações correspondentes aos grãos. Em cada metro amostral por parcela, foi contado o número total de grãos formados. Então, estes foram pesados, determinando-se a massa total de grãos por metro.

\subsubsection{Número e massa de grãos comerciais por metro} Como grãos comerciais, foram considerados todos aqueles retidos em peneiras de furos circulares com os seguintes diâmetros em 64 avos de polegada: peneiras 24, 23, $22,21,20,19$ e 18, provenientes ou não de vagens comerciais. Os demais grãos não retidos por essas peneiras foram considerados "não comerciais" ou descartáveis. Então, os grãos comerciais foram pesados, determinando-se a massa de grãos comerciais por metro.

\subsubsection{Número e massa total de grãos por planta}

obtidos pela divisão do número total de grãos por metro pela população final e pela divisão da massa total de grãos por metro pela população final, respectivamente.

\subsubsection{Número e massa de grãos comerciais por planta} obtidos pela divisão do número de grãos comerciais por metro pela população final e pela divisão da massa de grãos comerciais por metro pela população final, respectivamente.

3.7.13. Rendimento total de grãos comerciais por vagem Obtido pela divisão da massa de grãos 
comerciais por metro pelo massa total de vagens por metro.

\subsubsection{Rendimento agrícola}

Foi determinado através da pesagem da produção total de vagens da área útil de cada parcela, seguido de posterior conversão de $\mathrm{g} /$ parcela para $\mathrm{kg} / \mathrm{ha}$.

\subsection{Delineamento experimental}

Em ambos os experimentos (com e sem calagem) foi utilizado o delineamento experimental de acordo com 0 esquema fatorial $3 \times 2 \times 2$ com 4 tratamentos adicionais (testemunhas) em blocos casualizados com 3 repetições.

- esquema da análise de variância realizada para cada experimento e cultivo, encontra-se na tabela 2.

Tabela 2. Esquema de análise de variância dos dados para cada experimento (com e sem calagem) e cultivo (águas e seca)

\begin{tabular}{|c|c|c|}
\hline $\mathrm{CV}$ & & GI \\
\hline Blocos & & 02 \\
\hline Testemunhas vs. Fatorial & $Y(I)^{1}$ & 01 \\
\hline $\mathrm{T} 1$ vs $\mathrm{T} 2, \mathrm{~T} 3$ e $\mathrm{T} 4$ & $Y(2)^{2}$ & 01 \\
\hline $\mathrm{T} 2$ vs $\mathrm{T} 3$ e $\mathrm{T} 4$ & $Y(3)^{3}$ & 01 \\
\hline $\mathrm{T} 3$ vs $\mathrm{T} 4$ & $Y(4)^{4}$ & 01 \\
\hline Gesso agrícola & $(G)$ & 02 \\
\hline Época & $(E)$ & 01 \\
\hline Local & (L) & 01 \\
\hline Interação G x E & & 02 \\
\hline Interação G x L & & 02 \\
\hline Interação L x E & & 01 \\
\hline Resíduo & & 32 \\
\hline Total & & 47 \\
\hline
\end{tabular}


A partir dos quatro tratamentos adicionais (testemunhas), montou-se os quatro contrastes, que serão descritos a seguir:

Contraste 1: confronto entre tratamentos com e sem aplicação de gesso agrícola.

$$
\begin{aligned}
& Y(1)=\text { testemunhas vs. fatorial } \\
& Y(1)=3 \mathrm{~T} 1+3 \mathrm{~T} 2+3 \mathrm{~T} 3+3 \mathrm{~T} 4-\mathrm{T} 5-\mathrm{T} 6 \ldots-\mathrm{T} 15-\mathrm{T} 16
\end{aligned}
$$

Contraste 2: confronto entre tratamentos com e sem aplicação de fósforo e potássio na semeadura.

$$
\begin{aligned}
& \mathrm{Y}(2)=\mathrm{T} 1 \text { vs. T2, T3 e T4 } \\
& \mathrm{Y}(2)=3 \mathrm{~T} 1-\mathrm{T} 2-\mathrm{T} 3-\mathrm{T} 4+0 \mathrm{~T} 5+0 \mathrm{~T} 6 \ldots+0 \mathrm{~T} 15+0 \mathrm{~T} 16
\end{aligned}
$$

Contraste 3: confronto entre tratamentos com aplicação de superfosfato simples $e$ os tratamentos com aplicação de superfosfato triplo.

$$
\begin{aligned}
& \mathrm{Y}(3)=\mathrm{T} 2 \text { vs. T3 e } \mathrm{T} 4 \\
& \mathrm{Y}(3)=0 \mathrm{~T} 1+2 \mathrm{~T} 2-\mathrm{T} 3-\mathrm{T} 4+0 \mathrm{~T} 5+0 \mathrm{~T} 6 \ldots+0 \mathrm{~T} 15+0 \mathrm{~T} 16
\end{aligned}
$$

Contraste 4: confronto entre os tratamentos com aplicação de superfosfato triplo com e sem aplicação de enxofre.

$$
\begin{aligned}
& \mathrm{Y}(4)=\mathrm{T} 3 \mathrm{vs} . \mathrm{T} 4 \\
& \mathrm{Y}(4)=0 \mathrm{~T} 1+0 \mathrm{~T} 2+\mathrm{T} 3-\mathrm{T} 4+0 \mathrm{~T} 5+0 \mathrm{~T} 6 \ldots+0 \mathrm{~T} 15+0 \mathrm{~T} 16
\end{aligned}
$$

Com relação à parte fatorial, foi utilizado o "software" estatístico 'SANEST', que forneceu equações de regresssão linear ou quadrática, quando foram verificadas diferenças estatísticamente significativas entre as doses de 400,800 e $1200 \mathrm{~kg} / \mathrm{ha}$ de gesso agrícola. A equação resultante, pode ser assim descrita: 


$$
Y=C+B \cdot X+A \cdot X^{2} \quad \text { onde, }
$$

$X$ - Dose de gesso agrícola aplicada (entre 400 e $1200 \mathrm{~kg} / \mathrm{ha})$;

A, B, e C - Coeficientes calculados pelo 'SANEST'. Para as regressões lineares o coeficiente A é zero;

$Y$ - Valor da determinação, por exemplo, kg/ha de vagens comerciais por metro ou plantas por metro linear.

Toda a metodologia de análise estatística utilizada na presente pesquisa foi descrita por GoMES (1978) e desenvolvida com apoio de NOGUEIRA ${ }^{2}$. Os quadrados médios relativos às análises estatísticas realizadas, encontram-se em anexo.

2NOGUEIRA, M.C.S. (Profa. Associada do Departamento de Matemática e Estatística da ESALQ/USP). Orientação pessoal, 1992. 


\section{RESULtados E DIscUSSÃo}

De acordo com a elaboração do trabalho, os resultados e discussões são apresentados separadamente para as áreas com e sem calcário, visando facilitar a sua compreensão. Dentro de cada área, são discutidos os resultados do cultivo 'das águas' conjuntamente com o cultivo 'da seca' (efeito residual dos tratamentos do cultivo anterior).

\subsection{Desenvolvimento e rendimento agrícola em presença} de calcário

Os resultados a respeito do desenvolvimento e rendimento agrícola em presença de calcário, estão apresentados nas tabelas 3 a 6 . Os valores relativos às interações entre doses de gesso agrícola, local e época de aplicação, só serão apresentados quando estatisticamente significativos e no decorrer do texto. Os valores de quadrados médios relativo às análises estatísticas efetuadas, encontram-se em anexo (tabelas 29 a 32 ).

\subsubsection{Indice de velocidade de emergência}

Não foi observada diferença estatisticamente significativa, em nenhum dos dois cultivos, para os tratamentos testados (tabelas 3 a 6 ).

\subsubsection{População inicial}

Não foi observada diferença estatisticamente 
significativa, em nenhum dos dois cultivos, para os tratamentos testados (tabelas 3 a 6 ).

Para o cultivo 'das águas', a população inicial de plantas apresentou-se bem abaixo da população final. Isto foi acarretado pelos altos índices pluviométricos, que dificultaram e reduziram a qualidade do preparo do solo, tornando o leito de semeadura irregular e gerando emergência tardia de plântulas (tabelas 3 e 5 ).

\subsubsection{População final}

A única diferença significativa encontrada nos dois cultivos, ocorreu para a interação de doses de gesso agrícola com épocas de aplicação, dentro do cultivo 'das águas'.

Neste caso, não houve significância estatística para doses de gesso agrícola dentro das épocas de aplicação. Houve significância estatística ao nível de 5\%, para épocas de aplicação dentro de $400 \mathrm{~kg} / \mathrm{ha}$ de gesso agrícola, onde a aplicação no florescimento superou a aplicação na semeadura (19,3 contra 15,3 plantas por metro linear, respectivamente).

\subsubsection{Número total de vagens por metro}

Para o cultivo 'das águas' somente a interação de doses de gesso agrícola com épocas de aplicação, foi estatisticamente significativa a $1 \%$ de significância.

Houve diferença estatística para doses de gesso agrícola dentro de aplicação na semeadura. Como resultado estatístico, obteve-se a equação linear:

$$
\mathrm{Y}=155,3333+0,075833 \mathrm{X} \text { onde, }
$$

Y representa o número total de vagens por metro e $X, a$ dose de gesso agrícola. Houve ainda, diferença significativa para época de aplicação dentro de 400 e dentro de $1200 \mathrm{~kg} / \mathrm{ha}$ de gesso agrícola. Em relação à primeira, houve superioridade da aplicação do gesso agrícola no florescimento 
em relação a semeadura $(240,2$ contra 185,7 vagens totais por metro, respectivamente). Já para a dose de $1200 \mathrm{~kg} / \mathrm{ha}$, ocorreu - inverso e a superioridade foi da aplicação na semeadura em relação a aplicação no florescimento $(246,3$ contra 213,3 vagens totais por metro, respectivamente). Este resultado se assemelha ao descrito para população final e como ele não ocorre para número total de vagens por planta, como será verificado adiante, admite-se que esta diferença ocorrida é conseqüência de diferenças na população final.

Para o cultivo 'da seca', a aplicação de gesso agrícola gerou uma superioridade estatística em relação a não aplicação do mesmo e a aplicação de fósforo e potássio também foi superior, estatisticamente, a não aplicação destes. Logo, estes tratamentos beneficiaram $\circ$ número total de vagens produzidas (tabela 4).

\subsubsection{Número de vagens comerciais por metro}

Para o cultivo 'das águas' somente a interação de doses de gesso agrícola com épocas de aplicação, foi estatisticamente significativa a 5응 de significância.

Não houve diferença estatística para doses de gesso agrícola dentro das épocas de aplicação. Houve diferença significativa para épocas de aplicação dentro de $400 \mathrm{~kg} / \mathrm{ha}$ de gesso agrícola, onde houve superioridade da aplicação no florescimento $(138,7$ contra 103,5 vagens comerciais por metro). Assim como no item anterior, estas diferenças não encontram correspondência no número de vagens comerciais por planta, assim sendo, admite-se que estas decorrem da população final.

Para o cultivo 'da seca', ocorreu superioridade significativa estatisticamente para a aplicação de gesso agrícola, isto é, a aplicação de gesso agrícola beneficiou o número de vagens comerciais por metro (tabela 4). Ao contrário do que ocorreu no item anterior, não houve superioridade 
estatística significativa para a aplicação de fósforo e potásio.

\subsubsection{Massa total de vagens por metro}

Para o cultivo 'das águas' somente a interação de doses de gesso agrícola com épocas de aplicação, foi estatisticamente significativa a 5음 de significância.

Houve diferença estatística para doses de gesso agrícola dentro de aplicação na semeadura. Como resultado estatístico, obteve-se a equação linear:

$$
\begin{aligned}
& \mathrm{Y}=134,9444+0,0695833 \mathrm{X} \text { onde, } \\
& \mathrm{Y} \text { representa a massa total de vagens por metro }
\end{aligned}
$$

e $X$, a dose de gesso agrícola. Houve diferença significativa para época de aplicação dentro de $400 \mathrm{~kg} / \mathrm{ha}$ de gesso agrícola. Houve superioridade da aplicação do gesso agrícola no florescimento em relação a semeadura $(210,7$ contra 161,8 gramas por metro, respectivamente). Este resultado se assemelha ao descrito para população final e como ele não ocorre para massa total de vagens por planta, como será verificado adiante, admite-se que esta diferença ocorrida é conseqüência de diferenças na população final.

Em relação ao cultivo 'da seca', a aplicação de gesso agrícola e a aplicação de fósforo e potássio, apresentaram superioridades estatisticamente significativas, em confronto com a não aplicação dos mesmos. Este resultado acompanha o que foi visto para o número total de vagens por metro e, assim como este, encontra correspondência na produção por planta, comprovando a influência destes sobre a massa total de vagens (tabela 4), assim como afirmaram Godoy et al. (s.d.) e Fornasieri et al. (1987).

\subsubsection{Massa de vagens comerciais por metro}

No cultivo 'das águas', não ocorreu diferença estatística, nem mesmo a interação de doses de gesso agrícola 
com épocas de aplicação, que havia ocorrido para o número de vagens comerciais por metro. Os demais tratamentos não apresentaram diferenças estatísticas, acompanhando os resultados obtidos para o número de vagens comerciais por metro (tabela 3 e 5).

No cultivo 'da seca', assim como ocorreu com o número de vagens comerciais por metro, houve superioridade, estatisticamente significativa, para a aplicação de gesso agrícola e não houve, para a aplicação de fósforo e potássio (tabela 4).

\subsubsection{Número total de vagens por planta}

No cultivo 'das águas', não ocorreu diferença estatisticamente significativa. Este fato comprova que as interações entre doses de gesso agrícola e épocas de aplicação, descritas para número total de vagens por metro como estatisticamente significativas, são resultantes da influência da variação de população final.

No cultivo 'da seca', não ocorreu diferença estatisticamente significativa. A aplicação de gesso agrícola, assim como a aplicação de fósforo e potássio, que haviam apresentado diferenças estatísticas para número total de vagens por metro, nesta determinação não apresentaram.

\subsubsection{Número de vagens comerciais por planta}

No cultivo 'das águas', não ocorreu diferença estatisticamente significativa. Este fato comprova que as interações entre doses de gesso agrícola e épocas de aplicação, descritas para número de vagens comerciais por metro, como estatisticamente significativas, são resultantes da influência da variação de população final.

No cultivo 'da seca', a aplicação de gesso agrícola apresentou superioridade a nivel estatístico, em comparação com a não aplicação do mesmo. Este resultado 
ratifica a influência positiva da aplicação de gesso agrícola em relação ao número de vagens comerciais produzidas. Como não houve diferença entre as 3 doses testadas, admite-se que a aplicação de $400 \mathrm{~kg} / \mathrm{ha}$ de gesso agrícola já foi suficiente para suprir as necessidades da cultura, neste aspecto (tabelas 4 e 6).

\subsubsection{Massa total de vagens por planta}

No cultivo 'das águas', não ocorreu diferença estatisticamente significativa. Este resultado segue $\circ$ resultado de número total de vagens por planta (tabelas 3 e 5 , além das interações).

No cultivo 'da seca', a aplicação de gesso agrícola apresentou superioridade a nível estatístico. Apesar de não haver diferença significativa para número total de vagens por planta, houve diferença significativa para a massa total de vagens por planta, o que demonstra um aumento na massa individual média de cada vagem, influenciado pela aplicação de gesso agrícola. Como não houve diferença entre as 3 doses testadas, admite-se que a aplicação de $400 \mathrm{~kg} / \mathrm{ha}$ de gesso agrícola já foi suficiente para suprir as necessidades da cultura, neste aspecto (tabelas 4 e 6 ).

\subsubsection{Massa de vagens comerciais por planta}

No cultivo 'das águas', não ocorreu diferença estatisticamente significativa. Este resultado segue o resultado de número de vagens comerciais por planta (tabelas 3 e 5, além das interações).

No cultivo 'da seca', a aplicação de gesso agrícola apresentou superioridade a nível estatístico. Levandose em consideração o resultado para número de vagens comerciais por planta, pode-se admitir que a superioridade da massa é conseqüência da superioridade do número. Como não houve diferença entre as 3 doses testadas, admite-se que a aplicação 
de $400 \mathrm{~kg} / \mathrm{ha}$ de gesso agrícola já foi suficiente para suprir as necessidades da cultura, neste aspecto (tabelas 4 e 6).

\subsubsection{Número total de grãos por metro}

Para o cultivo 'das águas' somente a interação de doses de gesso agrícola com épocas de aplicação, foi estatisticamente significativa a 5\% de significância.

Houve diferença estatística para doses de gesso agrícola dentro de aplicação na semeadura. Como resultado estatístico, obteve-se a equação linear:

$$
\begin{aligned}
& \mathrm{Y}=365,2222+0,1397917 \mathrm{X} \text { onde, } \\
& \mathrm{Y} \text { representa o número total de grãos por metro }
\end{aligned}
$$
e X, a dose de gesso agrícola. Houve diferença significativa para época de aplicação dentro de $400 \mathrm{~kg} / \mathrm{ha}$ de gesso agrícola. Houve superioridade da aplicação do gesso agrícola no florescimento em relação à semeadura $(521,8$ contra 418,8 número total de grãos por metro, respectivamente). Este resultado se assemelha ao descrito para população final e como ele não ocorre para número total de grãos por planta, como será verificado adiante, admite-se que esta diferença ocorrida é conseqüência da população final.

No cultivo 'da seca', houve diferença estatística significativa para gesso agrícola, fósforo e potássio e enxofre, sendo que a aplicação de gesso agrícola e de fósforo e potássio e a não aplicação de enxofre, mostraramse superiores, beneficiando o número de grãos produzidos por metro (tabela 4). Com exceção do enxofre elementar, os resultados são conseqüência dos obtidos para número total de vagens por metro. Com relação ao enxofre elementar, este resultado demonstra o efeito depressivo da aplicação do mesmo, em comparação a não aplicação.

\subsubsection{Número de grãos comerciais por metro}

No cultivo 'das águas', não ocorreu diferença 
estatisticamente significativa. A interação entre doses de gesso agrícola e épocas de aplicação ocorrida para número de vagens comerciais por metro, não se refletiu nesta determinação. Pode-se dizer que as diferenças ocorridas em relação a população final, não afetaram o número de grãos comerciais produzidos.

No cultivo 'da seca', a aplicação de gesso agrícola apresentou superioridade estatística. Este resultado está associado à superioridade estatística apresentada pelo número total de vagens por metro (tabela 4).

\subsubsection{Massa total de grãos por metro}

Para o cultivo 'das águas' somente a interação de doses de gesso agrícola com épocas de aplicação, foi estatisticamente significativa a 5 응 de significância.

Houve diferença estatística para doses de gesso agrícola dentro de aplicação na semeadura. Como resultado estatístico, obteve-se a equação linear:

$$
Y=93,9166+0,0444375 X \text { onde, }
$$

Y representa massa total de grãos por metro e $\mathrm{X}$, a dose de gesso agrícola. Houve diferença significativa para época de aplicação dentro de $400 \mathrm{~kg} / \mathrm{ha}$ de gesso agrícola. Houve superioridade da aplicação do gesso agrícola no florescimento em relação a semeadura $(142,4$ contra 110,1 gramas por metro, respectivamente). Este resultado se assemelha ao descrito para população final e como ele não ocorre para massa total de grãos por planta, como será verificado adiante, admite-se que esta diferença ocorrida é conseqüência da população final. Este resultado está associado ao obtido para número total de grãos por metro.

No cultivo 'da seca', seguindo o que já havia ocorrido com o número total de grãos por metro, a aplicação de gesso agrícola resultou em massa total de grãos por metro 
significativamente maior em comparação à não aplicação do mesmo (tabela 4).

\subsubsection{Massa de grãos comerciais por metro}

No cultivo 'das águas', não ocorreu diferença estatisticamente significativa. Esta não significância está associada a resultado semelhante obtido para número de grãos comerciais por metro (tabelas 3 e 5, além das interações).

- No cultivo 'da seca' a aplicação de gesso agrícola superou, a nível estatístico, a não aplicação do mesmo. Pode-se dizer que este resultado está associado à superioridade estatística ocorrida para número de grãos comerciais por metro (tabela 4).

\subsubsection{Número total de grãos por planta}

No cultivo 'das águas', não ocorreu diferença estatisticamente significativa. Este resultado comprova a influência das diferenças de população final sobre o resultado obtido para número total de grãos por metro.

No cultivo 'da seca', assim como ocorreu para número total de grãos por metro, a aplicação de gesso agrícola superou estatisticamente a não aplicação do mesmo. Este resultado comprova a influência positiva da aplicação de gesso agrícola sobre o número total de grãos produzidos. Como entre as doses testadas não se verificou diferença, admite-se que a dose de $400 \mathrm{~kg} / \mathrm{ha}$ de gesso agrícola foi suficiente para suprir as necessidades da cultura, neste aspecto (tabelas 4 e 6).

\subsubsection{Número de grãos comerciais por planta}

No cultivo 'das águas', não ocorreu diferença estatisticamente significativa (tabelas 3 e 5 ).

No cultivo 'da seca', assim como ocorreu para número de grãos comerciais por metro, a aplicação de gesso agrícola superou estatisticamente a não aplicação do mesmo. 
Este resultado comprova a influência positiva da aplicação de gesso agrícola sobre o número total de grãos produzidos. Como entre as doses testadas não se verificou diferença, admite-se que a dose de $400 \mathrm{~kg} / \mathrm{ha}$ de gesso agrícola foi suficiente para suprir as necessidades da cultura, neste aspecto (tabelas 4 e 6).

\subsubsection{Massa total de grãos por planta}

Com relação a esta determinação, o único tratamento que foi estatisticamente significativo, foi o efeito residual da aplicação de gesso agrícola que superou a não aplicação do mesmo, no cultivo 'da seca' (tabela 4). Este resultado está associado à diferença ocorrida para número total de grãos por planta. Como entre as doses testadas não se verificou diferença (tabela 6), admite-se que a dose de 400 $\mathrm{kg} / \mathrm{ha}$ de gesso agrícola foi suficiente para suprir as necessidades da cultura, neste aspecto.

\subsubsection{Massa de grãos comerciais por planta}

Com relação a esta determinação, o único tratamento que foi estatisticamente significativo, foi a aplicação de gesso agrícola que superou a não aplicação do mesmo, no cultivo 'da seca' (tabela 4). Este resultado está associado à diferença ocorrida para número de grãos comerciais por planta. Como entre as doses testadas não se verificou diferença (tabela 6), admite-se que a dose de $400 \mathrm{~kg} / \mathrm{ha}$ de gesso agrícola foi suficiente para suprir as necessidades da cultura, neste aspecto.

\subsubsection{Rendimento total de grãos comerciais por vagem}

Não foi observada diferença estatisticamente significativa, em nenhum dos dois cultivos, para os tratamentos testados. Este resultado indica que não ocorreram aumentos, a nível estatístico, na massa de grãos comerciais por vagem total 
em relação aos tratamentos testados (tabelas 3 a 6), ratificando o que foi afirmado por Sichmann (1966) e Nakagawa et al. (1966).

\subsubsection{Rendimento agrícola}

Não foi observada diferença estatisticamente significativa, para o cultivo 'das águas' (tabelas 3 e 5).

Para o cultivo 'da seca', a aplicação de gesso agrícola e a aplicação de fósforo e potássio resultaram em rendimento agrícola significativamente maior, do que a não aplicação dos mesmos. Com relação ao fósforo e potássio, os resultados obtidos da análise fitotécnica amostral (1 metro por parcela), discutida anteriormente, apenas apresentou diferença estatisticamente significativa para número e massa total de vagens por metro e para número total de grãos por metro. Este fato está associado à diferença numérica de população final, conjuntamente às diferenças numéricas existentes para os componentes da produção (tabela 4). Novamente, ratifica-se $\circ$ que foi dito por Sichmann (1966) e Nakagawa et al. (1966). Quanto aos modos de aplicação, ao contrário do que foi afirmado por Godoy et al. (s.d.) e Fornasieri et al. (1987), também não foram observadas diferenças significativas. Com relação às épocas de aplicação, os resultados obtidos ratificam o que foi relatado nestes trabalhos.

Assim como Godoy et al. (1992) afirmaram, muitas vezes os efeitos benéficos da aplicação de cálcio ocorrem a nível qualitativo e não quantitativo da produção.

\subsubsection{Considerações gerais}

De forma geral pode-se afirmar, para o cultivo 'das águas', que a não aplicação de fósforo e potássio apresentou uma superioridade numérica considerável à aplicação destes, em relação à maioria das determinações realizadas. As parcelas do tratamento com fósforo e potássio produziram maior 
volume de massa verde, em avaliação visual, e menor massa de vagens. A literatura consultada não esclarece, mas existem alguns relatos a respeito de tal fato, isto é, quando a planta vegeta mais do que é necessário, esta produz menos (tabela 3).

Ainda neste cultivo, com relação ao gesso agrícola, pode-se dizer que não houve diferença na aplicação, ou não, do mesmo, assim como entre as 3 doses testadas. Também não ocorreram diferenças para local e épocas de aplicação. Nada se pode afirmar à respeito da aplicação do enxofre elementar no plantio (tabelas 3 e 5 ).

No cultivo 'da seca', a aplicação de fósforo e potássio e a não aplicação de enxofre, apresentaram superioridade numérica considerável (por vezes estatisticamente) (tabela 4). Com relação ao gesso agrícola, o efeito residual da aplicação deste no cultivo 'das águas', apresentou superioridade a nível estatístico, para os componentes da produção. Como entre as doses testadas não se verificou diferença, admite-se que a dose de $400 \mathrm{~kg} / \mathrm{ha}$ de gesso agrícola foi suficiente para suprir as necessidades da cultura. Também não ocorreram diferenças para local e épocas de aplicação (tabelas 4 e 6 ).

Não foram verificadas diferenças significativas entre os tratamentos a base de superfosfatos, simples e triplo. 


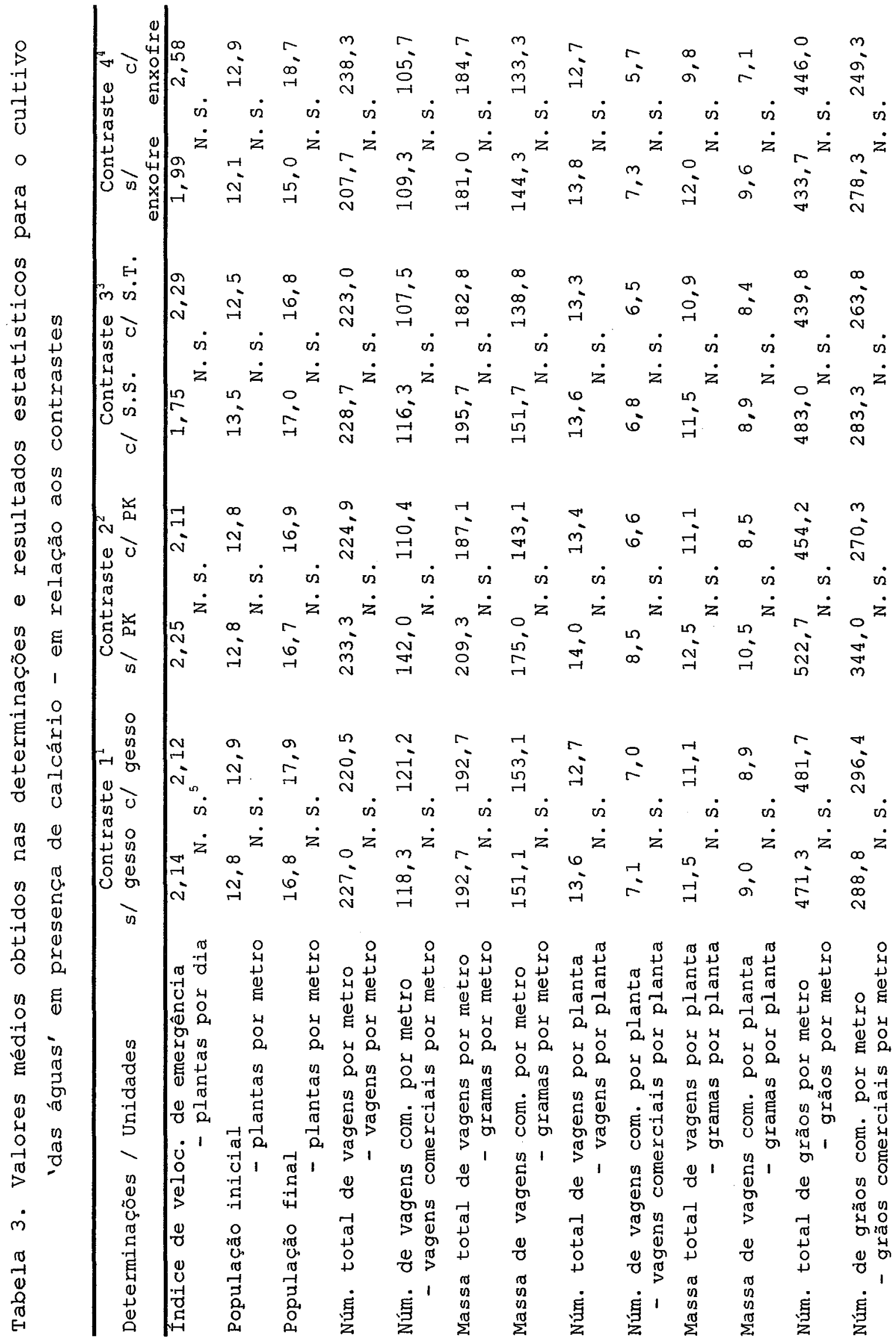




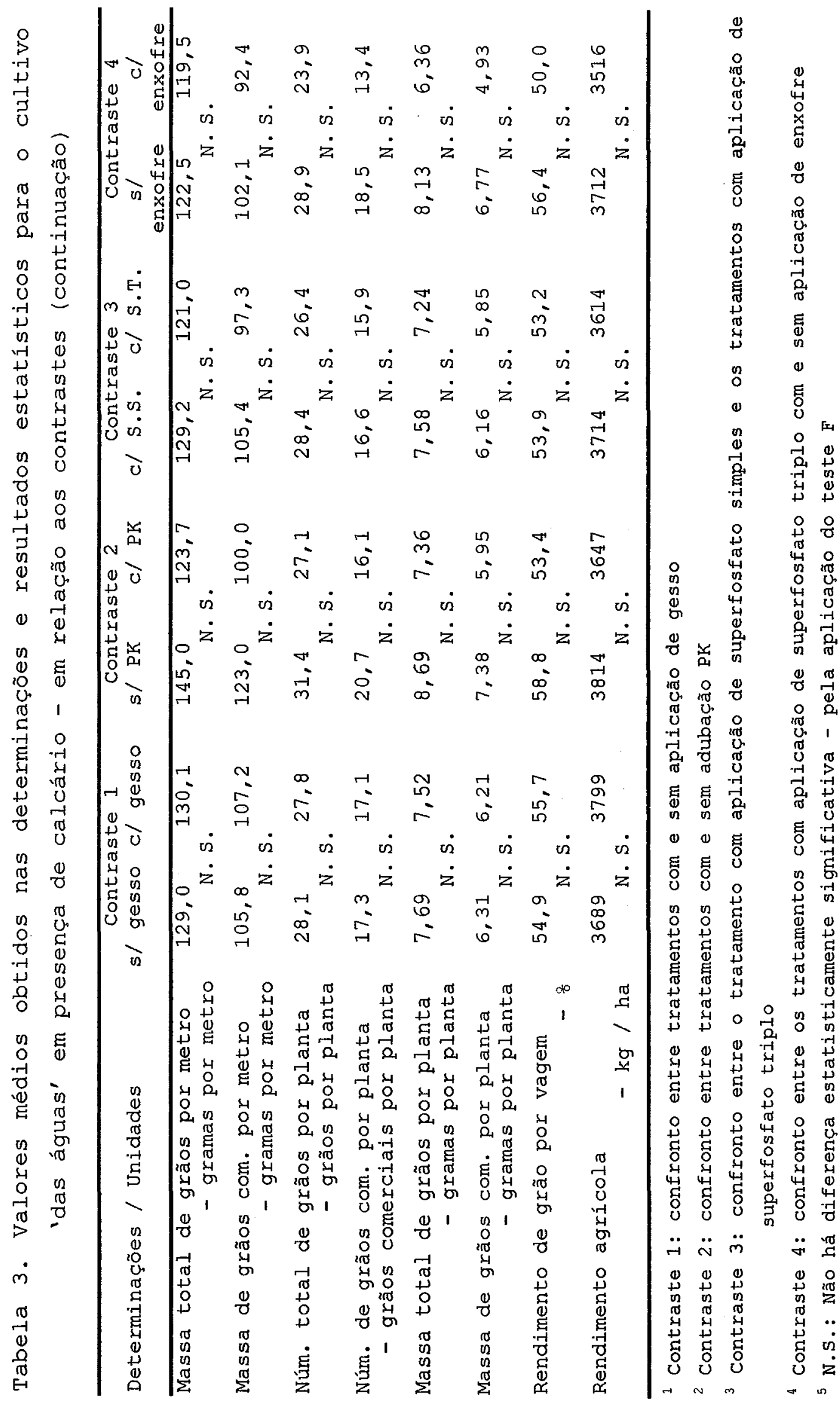




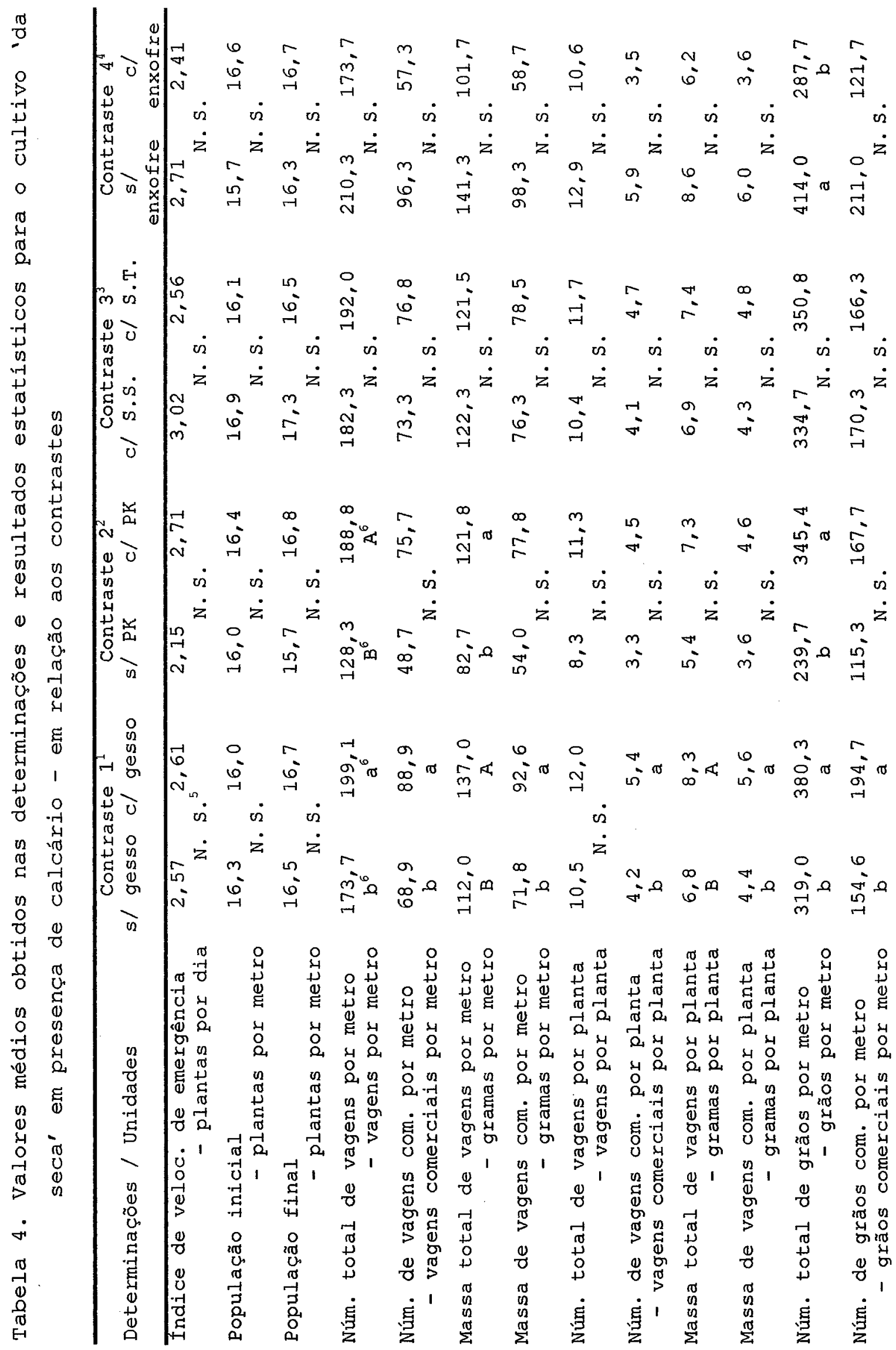




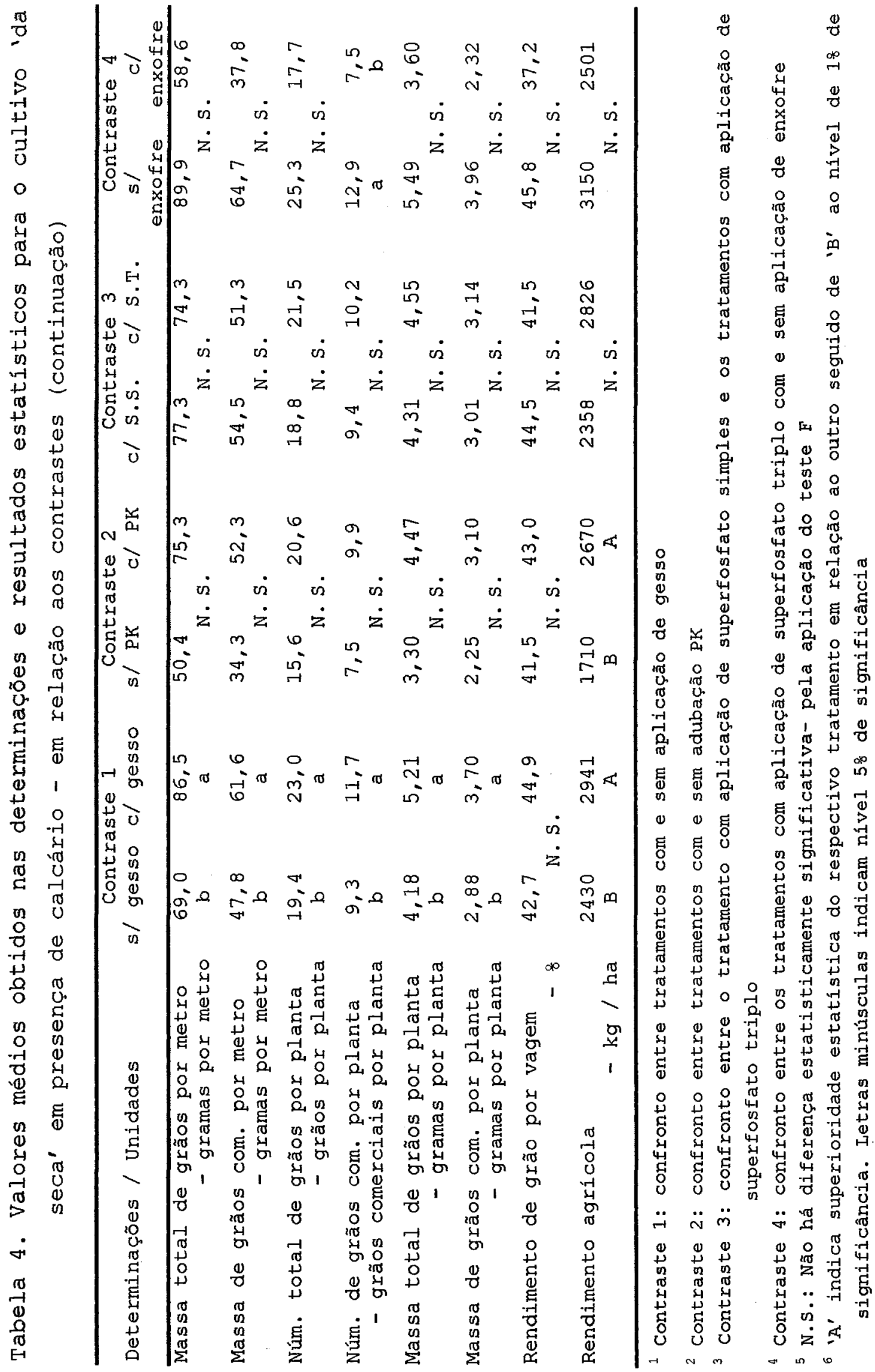




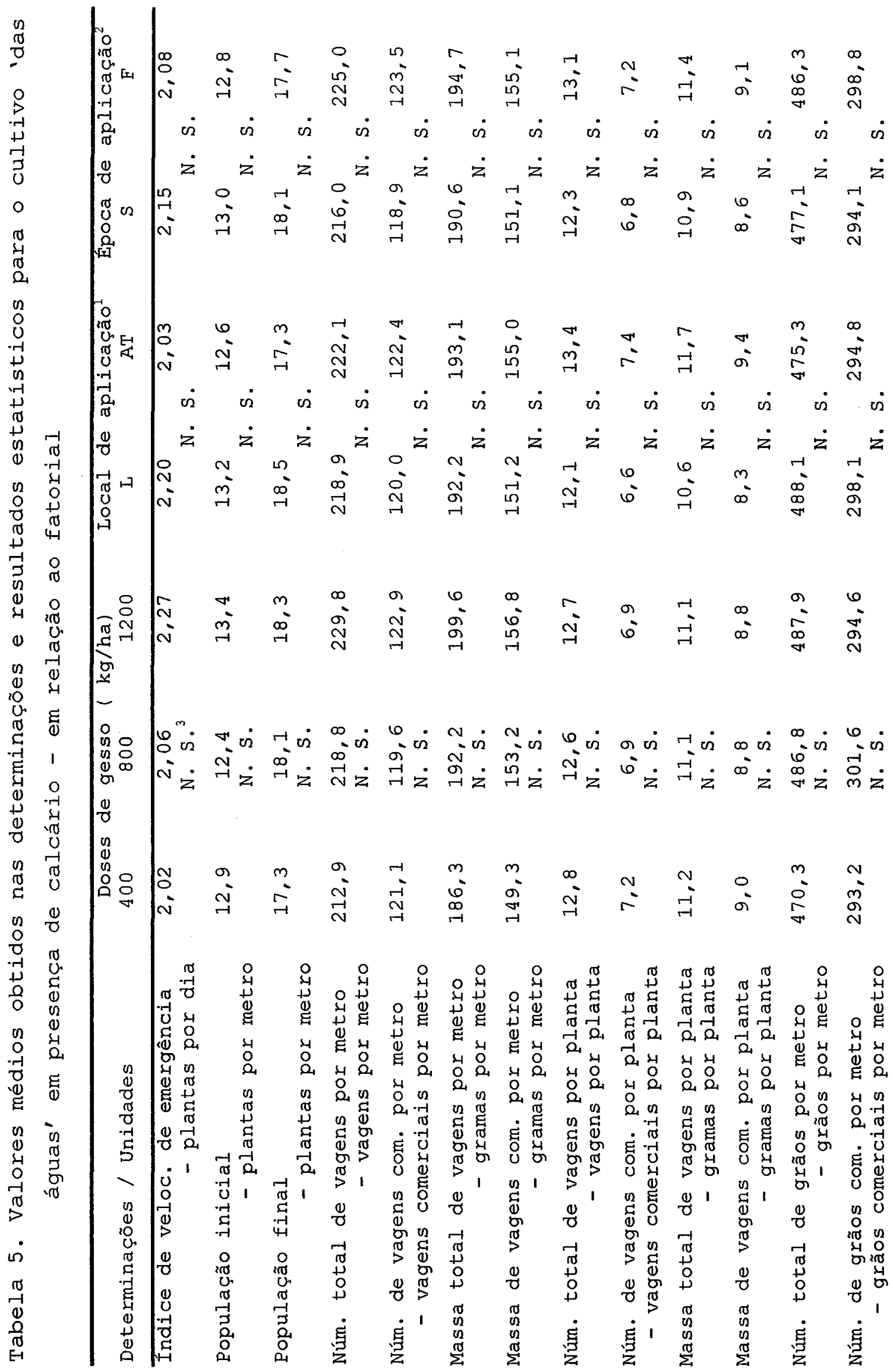




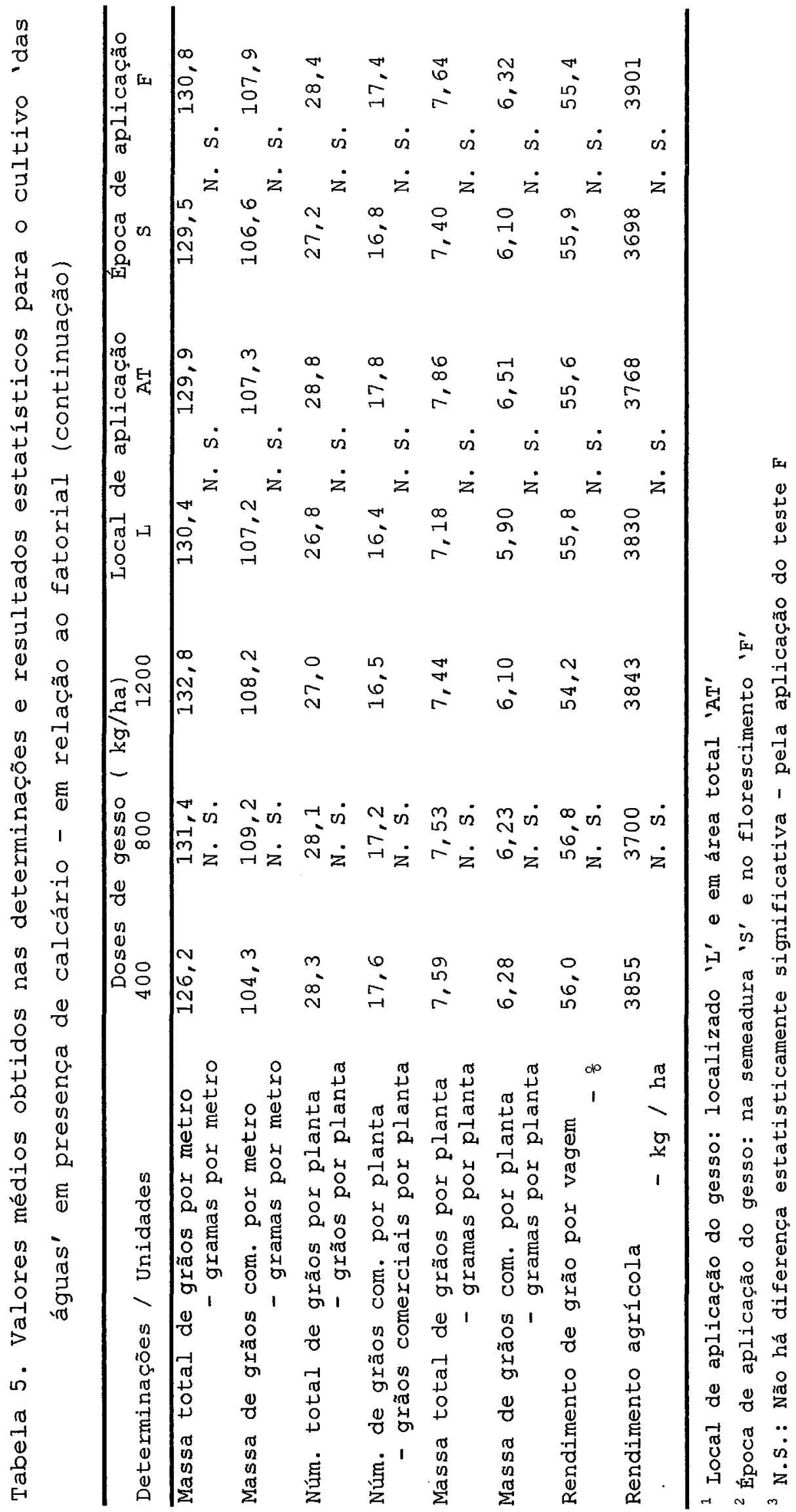




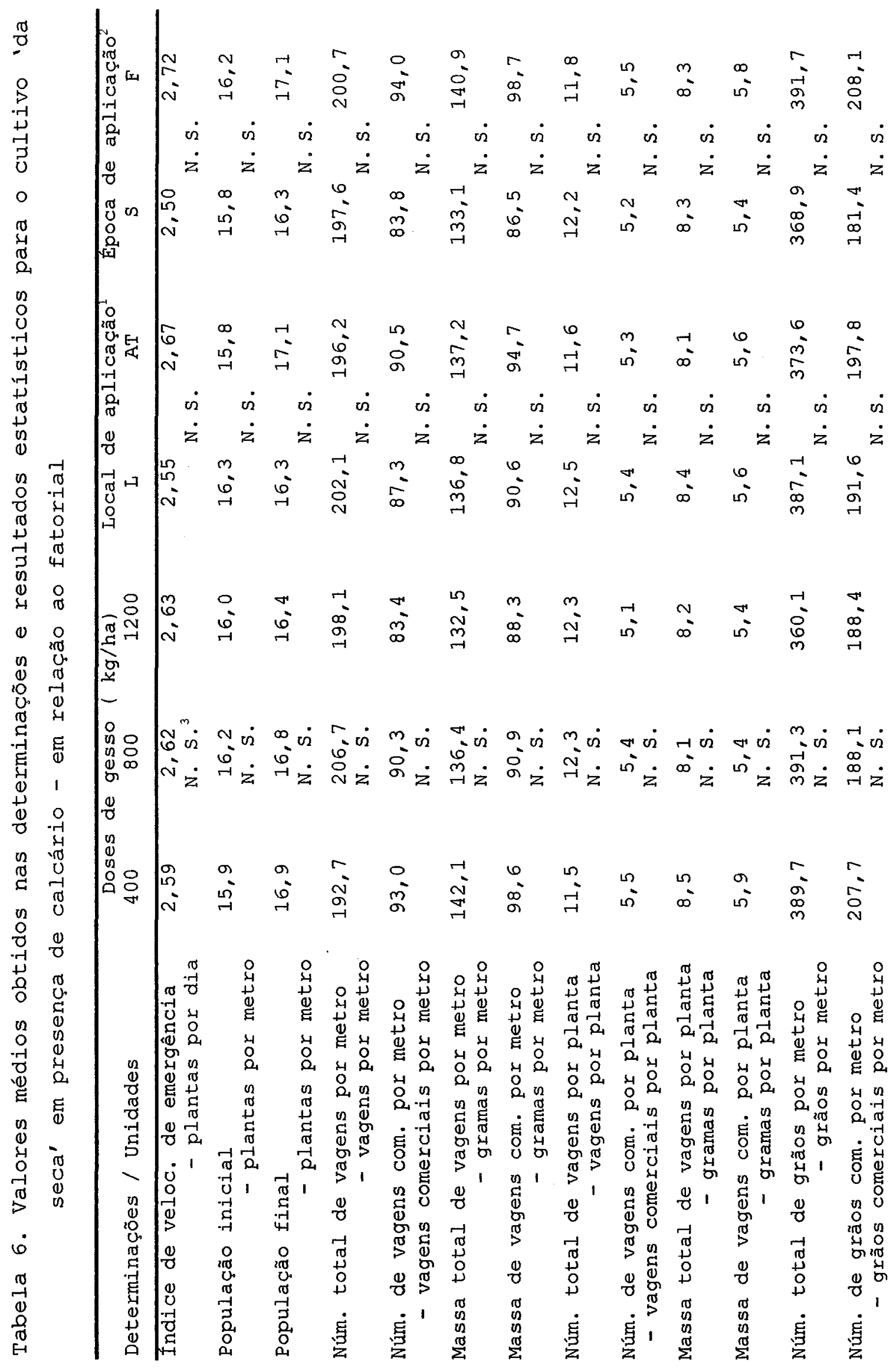




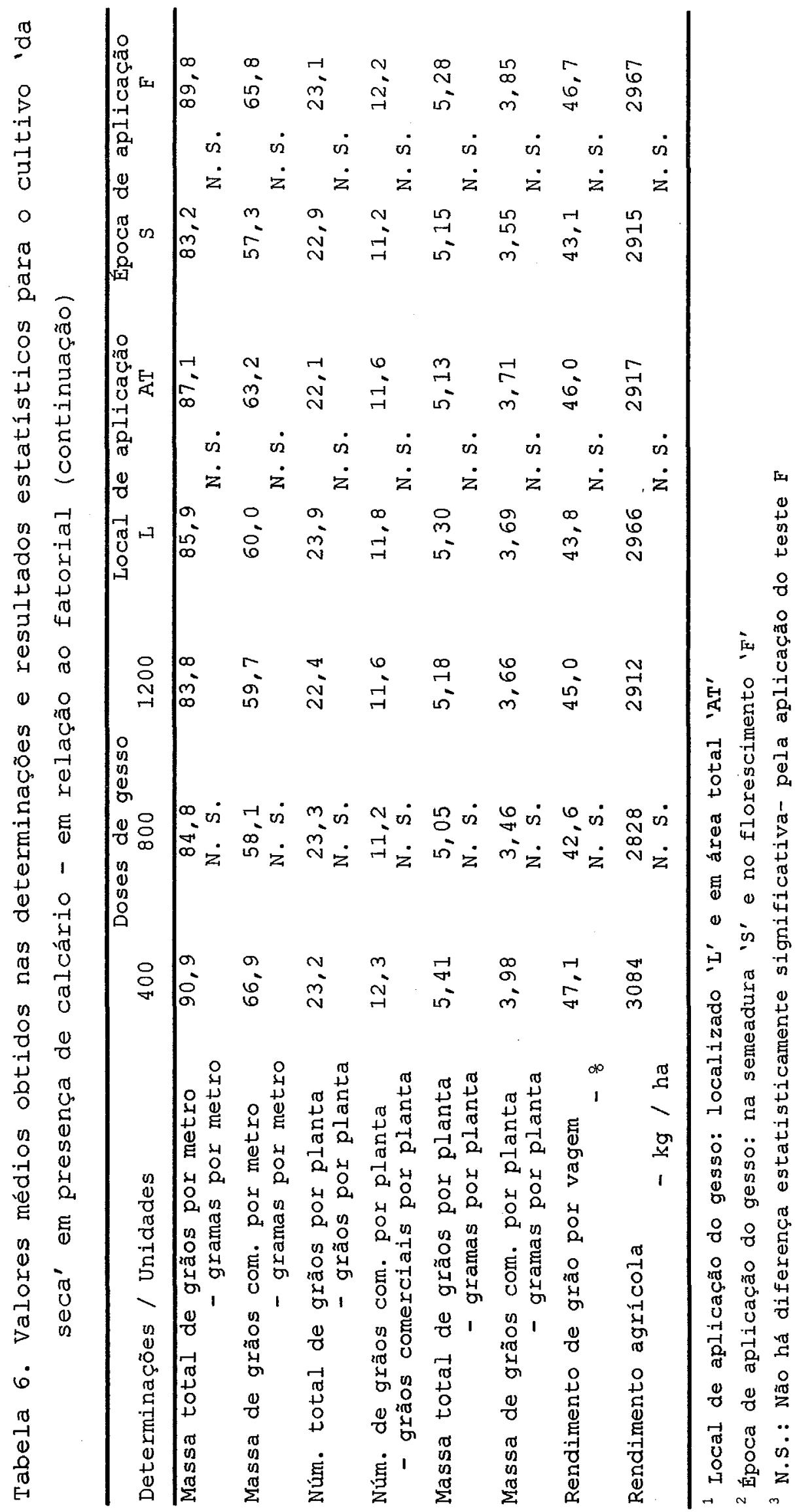


4.2. Desenvolvimento e rendimento agrícola em ausência de calcário

Os resultados a respeito do desenvolvimento e rendimento agrícola em ausência de calcário, são apresentados nas tabelas 7 a 10 . Os valores relativos às interações entre doses de gesso agrícola, local e época de aplicação, só serão apresentados quando estatisticamente significativos e no decorrer do texto. Os valores de quadrados médios relativo às análises estatísticas efetuadas, encontram-se em anexo (tabelas 33 a 36 ).

\subsubsection{Indice de velocidade de emergência}

Não foi observada diferença estatisticamente significativa, em nenhum dos dois cultivos, para os tratamentos testados (tabelas 7 a 10).

\subsubsection{População inicial}

Para o cultivo 'das águas' somente a interação de doses de gesso agrícola com épocas de aplicação, foi estatisticamente significativa a 5\% de significância.

Houve diferença estatística para doses de gesso agrícola dentro de aplicação na semeadura. Como resultado estatístico, obteve-se a equação linear:

$$
\begin{aligned}
& \mathrm{Y}=15,2778+0,0010625 \mathrm{X} \text { onde, } \\
& \mathrm{Y} \text { representa a população inicial e X, a dose de }
\end{aligned}
$$
gesso agrícola. Houve diferença estatisticamente significativa para época de aplicação dentro de $1200 \mathrm{~kg} / \mathrm{ha}$ de gesso agrícola. Houve superioridade da aplicação na semeadura em relação a aplicação no florescimento $(16,8$ contra 15,6 plantas por metro, respectivamente) .

Para o cultivo 'da seca', também ocorreu significância estatística para a interação entre doses de gesso agrícola e épocas de aplicação. Houve diferença estatística para doses de gesso agrícola dentro de aplicação no 
florescimento. Como resultado estatístico, obteve-se a equação linear:

$$
\begin{aligned}
& Y=18,1500-0,0011458 \mathrm{X} \text { onde, } \\
& Y \text { representa a população inicial e X, a dose de }
\end{aligned}
$$
gesso agrícola. Houve superioridade da aplicação na semeadura em relação a aplicação no florescimento $(17,5$ contra 16,6 plantas por metro, respectivamente), dentro de $1200 \mathrm{~kg} / \mathrm{ha}$ de gesso agrícola.

Ainda neste cultivo, a aplicação de fósforo e potássio superou estatisticamente a não aplicação do mesmo (tabela 8).

\subsubsection{População final}

Não foi observada diferença estatisticamente significativa, em nenhum dos dois cultivos, para os tratamentos testados (tabelas 7 a 10 ).

\subsubsection{Número total de vagens por metro}

Não foi observada diferença estatisticamente significativa, no cultivo 'das águas', para os tratamentos testados (tabelas 7 e 9 ).

No cultivo 'da seca' somente a aplicação de fósforo e potássio superou estatisticamente a não aplicação dos mesmos. Este resultado encontra respaldo no número total de vagens por planta, como será mostrado adiante (tabela 8).

\subsubsection{Número de vagens comerciais por metro}

Não foi observada diferença estatisticamente significativa, no cultivo 'das águas', para os tratamentos testados (tabelas 7 e 9).

No cultivo 'da seca' somente a aplicação de fósforo e potássio superou estatisticamente a não aplicação dos mesmos, assim como ocorreu no item anterior. 


\subsubsection{Massa total de vagens por metro}

Não foi observada diferença estatisticamente significativa, no cultivo 'das águas', para os tratamentos testados (tabelas 7 e 9).

No cultivo 'da seca' somente a aplicação de fósforo e potássio superou estatisticamente a não aplicação dos mesmos (tabela 8), assim como nos itens anteriores.

\subsubsection{Massa de vagens comerciais por metro}

Não foi observada diferença estatisticamente significativa, no cultivo 'das águas', para os tratamentos testados (tabelas 7 e 9 ).

No cultivo 'da seca' a aplicação de fósforo e potássio superou estatisticamente a não aplicação dos mesmos. Este resultado está associado ao obtido para número de vagens comerciais por metro (tabela 8 ).

\subsubsection{Número total de vagens por planta}

Não foi observada diferença estatisticamente significativa, no cultivo 'das águas', para os tratamentos testados (tabelas 7 e 9).

No cultivo 'da seca' a aplicação de fósforo e potássio superou estatisticamente a não aplicação dos mesmos. Este resultado comprova o efeito positivo da aplicação de fósforo e potássio sobre o número total de vagens produzidas (tabela 8).

Ainda com relação a este cultivo, a interação entre doses de gesso agrícola e épocas de aplicação, apresentou diferenças estatisticamente significativas, ao nível de 5o de significância. Houve diferença estatística para doses de gesso agrícola dentro de aplicação no florescimento. Como resultado estatístico, obteve-se a equação linear:

$$
Y=8,6333+0,0032083 \mathrm{X} \text { onde, }
$$


Y representa o número total de vagens por planta e $\mathrm{X}$, a dose de gesso agrícola. Houve superioridade da aplicação no florescimento em relação à aplicação na semeadura $(12,7$ contra 10,2 vagens totais por planta, respectivamente), dentro de $1200 \mathrm{~kg} / \mathrm{ha}$ de gesso agrícola.

\subsubsection{Número de vagens comerciais por planta}

No cultivo 'das águas' as doses de gesso agrícola apresentaram diferença estatística significativa, sendo que este resultado esta associado, em parte, à diferença numérica verificada para população final (maior espaço por planta, gerando mais vagens e/ou mais vagens comerciais por planta). A equação obtida indica que o maior número de vagens comerciais por planta corresponde à aplicação de $767 \mathrm{~kg} / \mathrm{ha}$ de gesso agrícola, isto é, com $\mathrm{X}=767$, tem-se o máximo número de vagens comerciais por planta (Y) (tabela 9).

Com relação à interação entre as doses de gesso agrícola e as épocas de aplicação, não foi verificada a significância estatística ocorrida no cultivo 'da seca' para número de vagens comerciais por planta.

\subsubsection{Massa total de vagens por planta}

No cultivo 'das águas' as doses de gesso agrícola apresentaram diferença estatistica significativa. Comparando-se este resultado aos obtidos para número total de vagens por planta e número de vagens comerciais por planta, nota-se que esta diferença encontrada para massa total de vagens por planta, está associada, em parte, a uma maior porcentagem de vagens comerciais no montante de vagens totais produzidas. A equação obtida indica que a maior massa total de vagens por planta corresponde à aplicação de $754 \mathrm{~kg} / \mathrm{ha}$ de gesso agrícola, isto é, com $X=754$, tem-se a máxima massa total de vagens por planta (Y) (tabela 9). 
Com relação à interação entre doses de gesso agrícola e épocas de aplicação, não se observou a significância estatística ocorrida, no cultivo 'da seca', para número total de vagens por planta.

\subsubsection{Massa de vagens comerciais por planta}

No cultivo 'das águas' as doses de gesso agrícola apresentaram diferença estatística significativa (tabela 9). Este resultado está associado ao obtido para número de vagens comerciais por planta. A equação obtida indica que a maior massa de vagens comerciais por planta corresponde à aplicação de $739 \mathrm{~kg} / \mathrm{ha}$ de gesso agrícola, isto é, com X = 739, tem-se a máxima massa de vagens comerciais por planta ( $Y$ ).

Assim como ocorreu para número de vagens comerciais por planta, não houve diferença estatisticamente significativa para esta determinação, no cultivo 'da seca'.

\subsubsection{Número total de grãos por metro}

Não foi observada diferença estatisticamente significativa, no cultivo 'das águas', para os tratamentos testados (tabelas 7 e 9).

No cultivo 'da seca' a aplicação de fósforo e potássio superou estatisticamente a não aplicação destes. Este resultado está associado ao obtido para número total de vagens por metro (tabela 8).

\subsubsection{Número de grãos comerciais por metro}

Não foi observada diferença estatisticamente significativa, no cultivo 'das águas', para os tratamentos testados (tabelas 7 e 9).

No cultivo 'da seca' a aplicação de fósforo e potássio superou estatisticamente a não aplicação dos mesmos. Este resultado está associado ao obtido para número de vagens comerciais por metro (tabela 8). 


\subsubsection{Massa total de grãos por metro}

Não foi observada diferença estatisticamente significativa, no cultivo 'das águas', para os tratamentos testados (tabelas 7 e 9 ).

No cultivo 'da seca' a aplicação de fósforo e potássio superou estatisticamente a não aplicação dos mesmos. Este resultado está associado ao obtido para número total de grãos por metro (tabela 8).

\subsubsection{Massa de grãos comerciais por metro}

Não foi observada diferença estatisticamente significativa, no cultivo 'das águas', para os tratamentos testados (tabelas 7 e 9).

No cultivo 'da seca' a aplicação de fósforo e potássio superou estatisticamente a não aplicação dos mesmos. Este resultado está associado ao obtido para número de grãos comerciais por metro (tabela 8 ).

\subsubsection{Número total de grãos por planta}

Não foi observada diferença estatisticamente significativa, em nenhum dos dois cultivos, para os tratamentos testados (tabelas 7 a 10).

\subsubsection{Número de grãos comerciais por planta}

No cultivo 'das águas' as doses de gesso agrícola apresentaram diferença estatistica significativa. Levando-se em consideração o resultado obtido para número total de vagens por planta, nota-se que a diferença ocorrida para número de grãos comerciais por planta está associada a um aumento no número de grãos comerciais produzidos por vagem total. Este resultado sofreu influência da diferença (numérica) ocorrida para população final, isto é, existe um efeito compensatório por parte das plantas devido a menor população final, em relação à dose de $800 \mathrm{~kg} / \mathrm{ha}$ de gesso agrícola. A 
equação obtida indica que o maior número de grãos comerciais por planta corresponde à aplicação de $771 \mathrm{~kg} / \mathrm{ha}$ de gesso agrícola, isto é, com $\mathrm{x}=771$, tem-se o máximo número de grãos Comerciais por planta (Y) (tabela 9).

No cultivo 'da seca' a aplicação de fósforo e potássio superou estatisticamente a não aplicação destes. Este resultado está associado ao obtido para número total de vagens por planta (tabela 8).

\subsubsection{Massa total de grãos por planta}

No cultivo 'das águas' as doses de gesso agrícola apresentaram diferença estatística significativa. A equação obtida indica que a maior massa total de grãos por planta corresponde à aplicação de $745 \mathrm{~kg} / \mathrm{ha}$ de gesso agrícola, isto é, $\operatorname{com} X=745$, tem-se a máxima massa total de grãos por planta (Y)(tabela 9). Este resultado está associado ao maior número de grãos comerciais por planta.

Ao contrário dos resultados dos itens anteriores, não houve diferença estatisticamente significativa para esta determinação, no cultivo 'da seca'.

\subsubsection{Massa de grãos comerciais por planta}

No cultivo 'das águas' as doses de gesso agrícola apresentaram diferença estatística significativa. A equação obtida indica que a maior massa de grãos comerciais por planta corresponde à aplicação de $770 \mathrm{~kg} / \mathrm{ha}$ de gesso agrícola, isto é, com $X=770$, tem-se a máxima massa de grãos comerciais por planta (Y). Este resultado está associado ao obtido para número de grãos comerciais por planta (tabela 9).

Não foi observada diferença estatisticamente significativa, no cultivo 'da seca', para os tratamentos testados (tabelas 8 e 10).

\subsubsection{Rendimento total de grãos comerciais por vagem}

Não foi observada diferença estatisticamente 
significativa, no cultivo 'das águas', para os tratamentos testados (tabelas 7 e 9 ).

No cultivo 'da seca' a interação entre doses de gesso agrícola e locais de aplicação apresentou diferenças estatisticamente significativas, ao nível de $5 \frac{0}{0}$ de significância. Houve diferença estatística para doses de gesso agrícola dentro de aplicação localizada no sulco de plantio. Como resultado estatístico, obteve-se a equação linear:

$$
\begin{aligned}
& Y=60,5944-0,0103125 X \text { onde, } \\
& Y \text { representa } 0 \text { rendimento total de grãos }
\end{aligned}
$$
comerciais por vagem e $\mathrm{X}$, a dose de gesso agrícola. Não houve diferença entre aplicação localizada ou em área total, dentro das três doses de gesso agrícola.

\subsubsection{Rendimento agrícola}

Não foi observada diferença estatisticamente significativa, no cultivo 'das águas', para os tratamentos testados (tabelas 7 e 9).

No cultivo 'da seca' a aplicação de fósforo e potássio superou estatisticamente a não aplicação dos mesmos (tabela 8).

Estes resultados ratificam as afirmações de Sichmann (1966) e Nakagawa et al. (1966), de que a resposta a aplicação de cálcio nem sempre é constante sob as mesmas condições químicas de solo. Assim como afirma Godoy et al. (1992), esta resposta muitas vezes se dá a nível de qualidade e não de quantidade da produção.

Ao contrário do que foi afirmado por Gallo (1987), não obteve-se resposta à aplicação de cálcio em ausência de calcário, para solos apresentando baixos teores deste nutriente.

\subsubsection{Considerações gerais}

No cultivo 'das águas' a aplicação de fósforo e 
potássio mostrou-se numericamente superior a não aplicação dos mesmos. Em relação ao gesso agrícola, a aplicação deste mostrou ser numericamente superior à não aplicação do mesmo, em relação a produção de grãos comerciais por metro e por planta. Entre as doses, a de $800 \mathrm{~kg} / \mathrm{ha}$ foi superior as demais. Quando ocorreu diferença estatisticamente significativa (número e massa por planta), a equação obtida apontou doses próximas a $800 \mathrm{~kg} / \mathrm{ha}$ de gesso agrícola, como sendo a de máximo desempenho, mas esta mesma dose apresentou a menor população final, ou seja, as plantas podem ter produzido mais porque tinham mais espaço. Com relação às épocas e locais de aplicação, não foi verificada diferença. Com relação à aplicação do enxofre elementar e às fontes de fósforo, nada se pode afirmar.

No cultivo 'da seca' a aplicação de fósforo e potássio mostrou-se estatisticamente superior a não aplicação deste. A não aplicação de enxofre elementar superou numericamente a aplicação do mesmo. Com relação ao enxofre, vale salientar que Godoy et al. (1992) relata que a resposta às diferentes fontes de enxofre é diferenciada. Assim sendo, o enxofre do gesso agrícola pode causar menos problemas que o enxofre elementar. Não houve diferença entre as fontes de fósforo testadas.

Em relação ao gesso agrícola, não houve resposta significativa à aplicação do mesmo, assim como entre as 3 doses. Não foi verificada diferença em relação às épocas e locais de aplicação. 


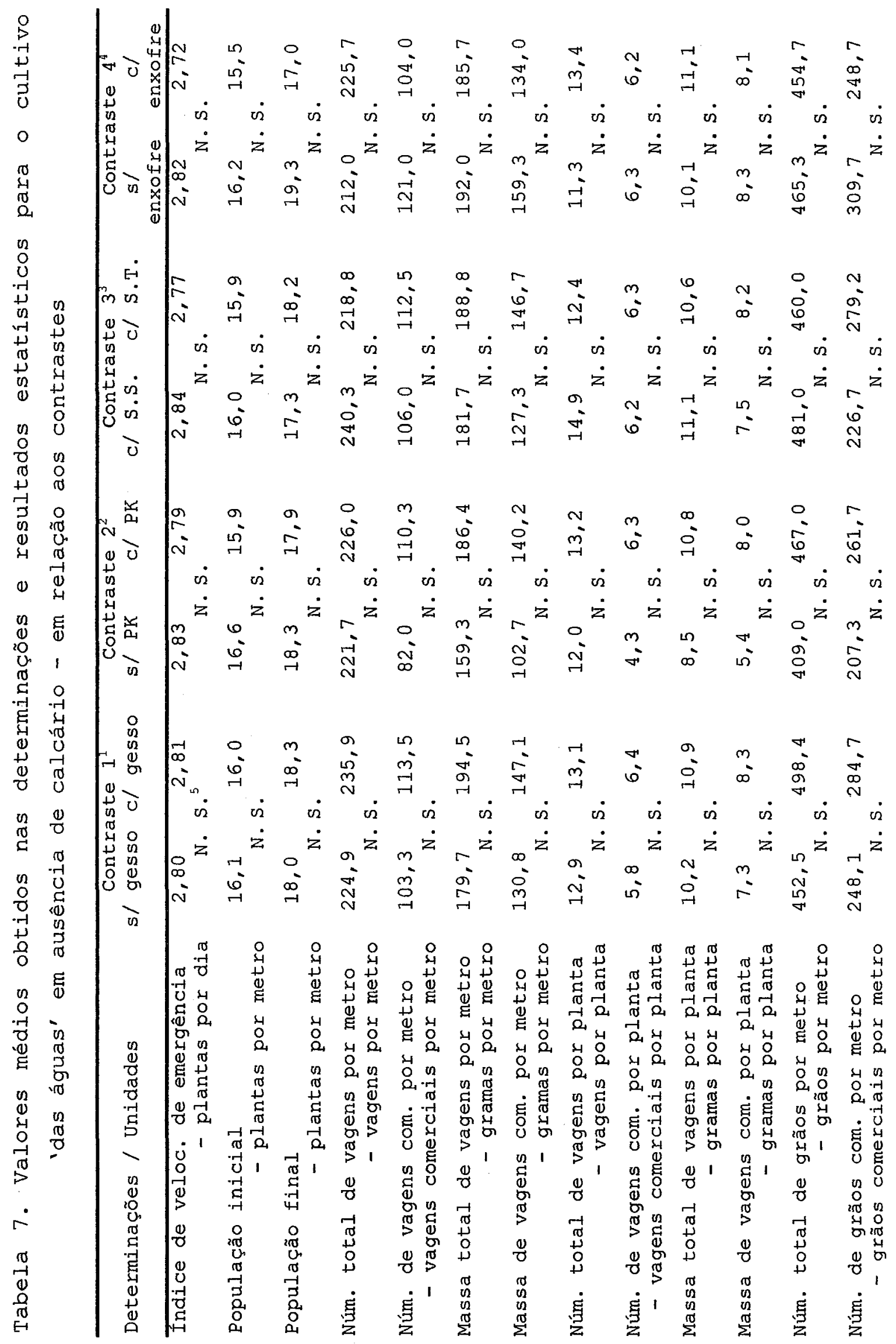




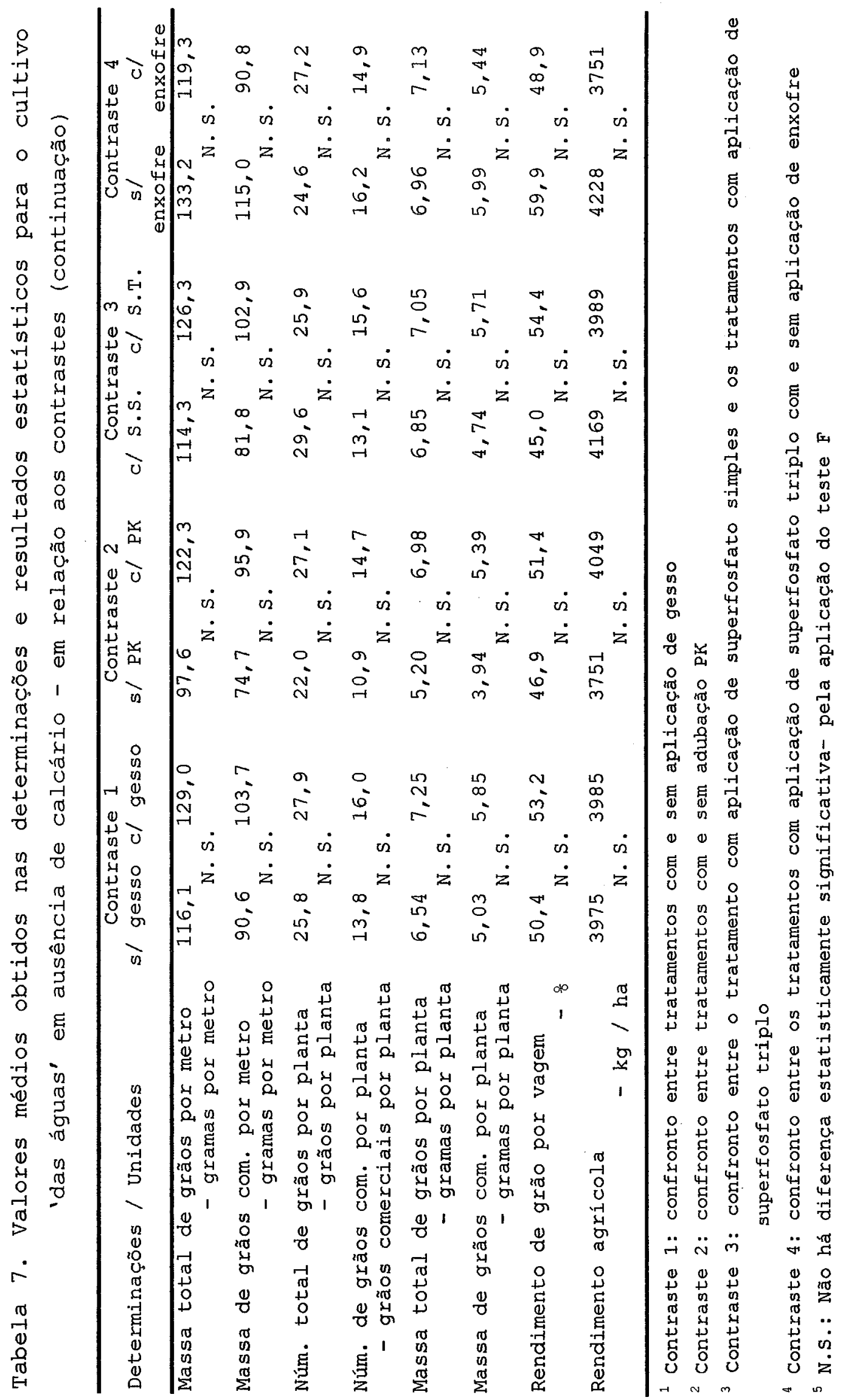




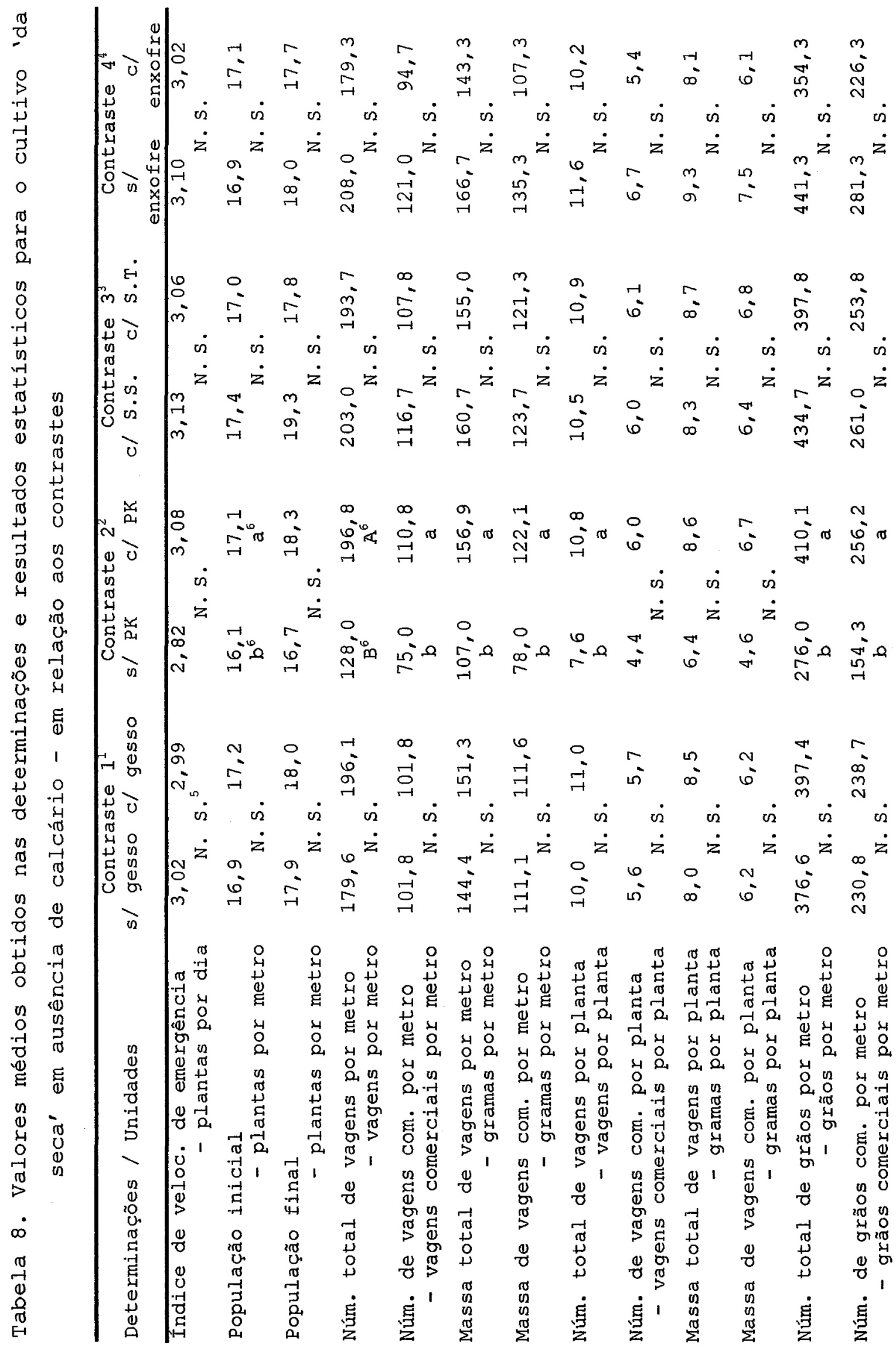




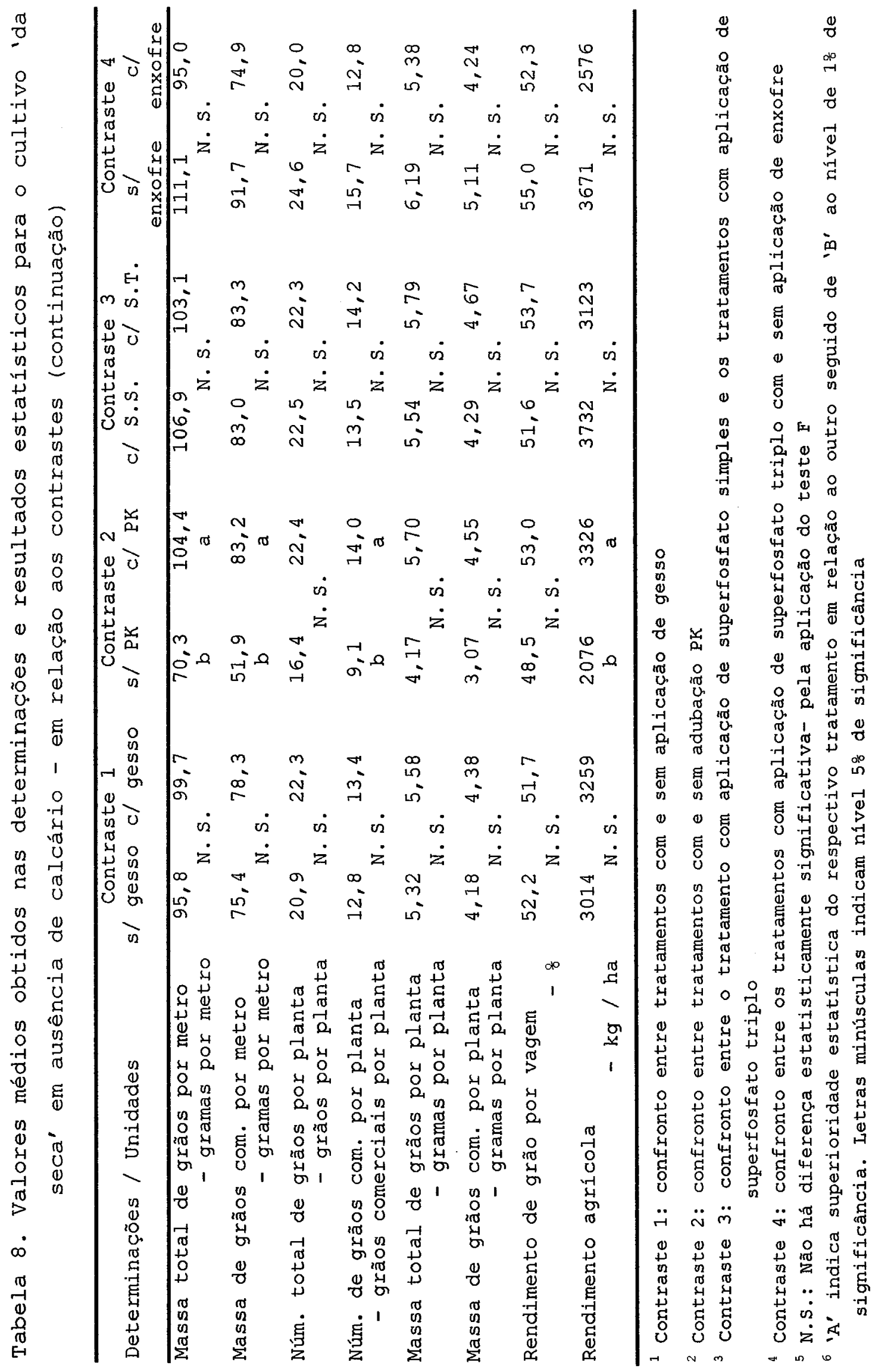









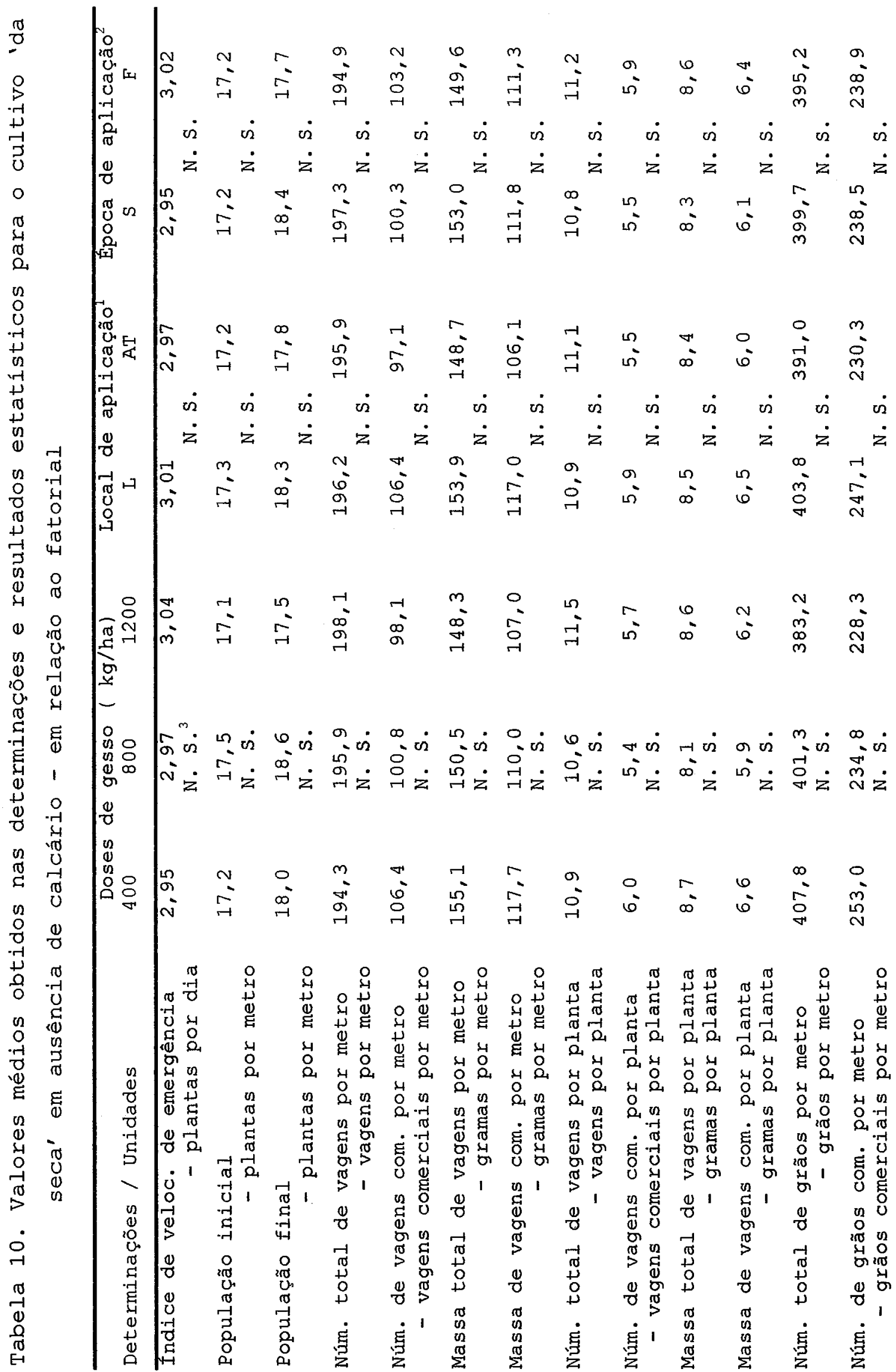




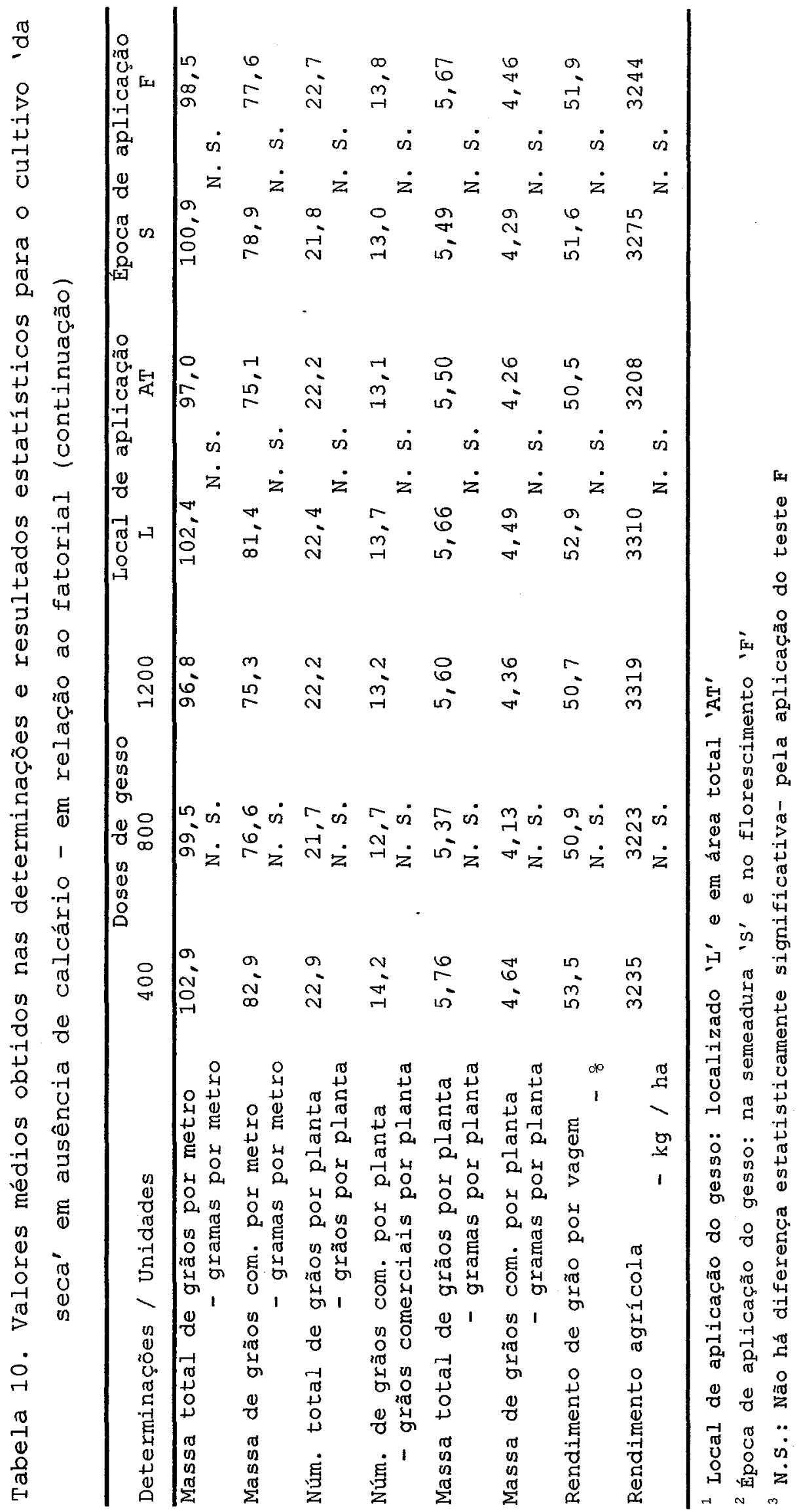




\subsection{Análises químicas do solo}

Embora não tenham sido objeto de análises estatísticas, os resultados das análises químicas de solo, correspondentes aos tratamentos estudados, permitem as seguintes discussões:

\subsubsection{Experimento en presença de calcário}

Neste experimento, na camada superficial lo a $10 \mathrm{~cm}$ de profundidade), foi verificado aumento no teor de potássio, ao contrário do que esperava-se (lixiviação por ação do gesso agrícola). Os teores de cálcio no solo não variaram entre os cultivos, mas aumentou de acordo com aumento da aplicação de gesso agrícola. Entre os locais e as épocas de aplicação do gesso agrícola, não houve diferença quanto aos teores dos nutrientes no solo. Houve redução no teor de magnésio do cultivo 'das águas' para o 'da seca' (tabelas 11 e 14).

Entre as camadas do solo de 0 a $10 \mathrm{~cm}$ e 10 a 20 $\mathrm{cm}$ de profundidade, foi verificada, de forma geral, redução nos teores de fósforo, cálcio, magnésio e aumento no teor de alumínio, ao descer-se no perfil (tabelas 11, 12, 14 e 15).

Com relação à camada de 10 a $20 \mathrm{~cm}$ de profundidade, foi verificado aumento no teor de potássio e redução no teor de magnésio do cultivo 'das águas' para o 'da seca". Em relação ao gesso agrícola, o aumento da aplicação reduziu o teor de magnésio no solo. Entre os locais e as épocas de aplicação do gesso agrícola, não houve diferença quanto aos teores dos nutrientes no solo (tabelas 12 e 15).

Entre as camadas do solo de 10 a $20 \mathrm{~cm}$ e 20 a $40 \mathrm{~cm}$ de profundidade, foi verificada, de forma geral, redução nos teores de fósforo, cálcio, magnésio e matéria orgânica e aumento no teor de alumínio, ao descer-se no perfil (tabelas $12,13,15$ e 16 ). 
Com relação à camada de 20 a $40 \mathrm{~cm}$ de profundidade, foi verificada redução no teor de magnésio do cultivo 'das águas' para o 'da seca", sendo que potássio, cálcio e alumínio, permaneceram estáveis. Em relação ao gesso agrícola, o aumento da aplicação reduziu o teor de magnésio no solo. Entre os locais e as épocas de aplicação do gesso agrícola, não houve diferença quanto aos teores dos nutrientes no solo (tabelas 13 e 16).

Com base nos resultados, pode-se afirmar que, nas condições deste experimento, o gesso agrícola não neutralizou o alumínio, aumentou o teor de cálcio apenas na camada superficial e contribuiu na lixiviação de magnésio pelo perfil (tabelas 11 a 16).

\subsubsection{Experimento em ausência de calcário}

Neste experimento, na camada superficial 10 a $10 \mathrm{~cm}$ de profundidade), os teores de cálcio, magnésio e matéria orgânica no solo, sofreram redução do cultivo 'das águas' para - 'da seca', enquanto o fósforo e o alumínio, aumentaram no mesmo período. Maiores doses de gesso agrícola, aumentaram o teor de cálcio e reduziram o de alumínio no solo, apenas no cultivo 'das águas'. Também no cultivo 'das águas', a aplicação de gesso agrícola localizada e/ou no florescimento, geraram maiores teores de cálcio no solo, em relação à aplicação em área total e/ou na semeadura (tabelas 17 e 20).

Entre as camadas do solo de 0 a $10 \mathrm{~cm}$ e 10 a 20 $\mathrm{cm}$ de profundidade, foi verificada, de forma geral, redução nos teores de fósforo e cálcio e aumento no teor de alumínio, ao descer-se no perfil (tabelas 17, 18, 20 e 21).

Com relação à camada de 10 a $20 \mathrm{~cm}$ de profundidade, foi verificado aumento no teor de fósforo e redução nos teores de magnésio e matéria orgânica do cultivo 'das águas' para o 'da seca'. Maiores doses de gesso agrícola, aumentaram o teor de cálcio (apenas no cultivo 'das águas') e 
reduziram o de alumínio no solo (ambos cultivos). Entre os locais e as épocas de aplicação do gesso agrícola, não houve diferença quanto aos teores dos nutrientes no solo (tabelas 18 e 21).

Entre as camadas do solo de 10 a $20 \mathrm{~cm}$ e 20 a $40 \mathrm{~cm}$ de profundidade, foi verificada, de forma geral, redução nos teores de fósforo, potássio e matéria orgânica e aumento nos teores de magnésio e alumínio, ao descer-se no perfil. Nota-se que os teores de cálcio e o magnésio que diminuiram nas camadas superiores, aumentaram na camada de 20 a $40 \mathrm{~cm}$ de profundidade (tabelas 18, 19, 21 e 22).

Com relação à camada de 20 a $40 \mathrm{~cm}$ de profundidade, foi verificada redução nos teores de cálcio, magnésio, alumínio e matéria orgânica do cultivo 'das águas' para o 'da seca", sendo que potássio e fósforo, permaneceram estáveis. Em relação ao gesso agrícola, maiores doses reduziram - teor de alumínio e aumentaram os teores de cálcio e magnésio no solo. Entre os locais e as épocas de aplicação do gesso agrícola, não houve diferença quanto aos teores dos nutrientes no solo (tabelas 19 e 22).

Com base nos resultados, pode-se afirmar que, nas condições deste experimento, o gesso agrícola neutralizou o alumínio ao longo do perfil, aumentou um pouco o teor de cálcio, mas contribuiu na lixiviação deste e do magnésio pelo perfil (tabelas 17 a 22 ).

\subsection{Análises foliares}

A comparação entre os resultados apresentados pelas tabelas 23, 24, 25 e 26, permitem as discussões que seguem.

Do cultivo 'das águas' para o cultivo 'da seca', não houve alteração dos teores de $\mathrm{Ca}$ e $\mathrm{Cu}$, enquanto os macronutrientes $\mathrm{N}$ e $\mathrm{S}$ e os micronutrientes $\mathrm{Fe} e \mathrm{Zn}$ apresentaram 
elevação. Por outro lado, os macronutrientes $P$ e $K$ e mais os micronutrientes $\mathrm{B}$ e $\mathrm{Mn}$ apresentaram diminuição em seus teores, de um cultivo para o outro, tanto nas áreas com e sem calcário.

Apenas o macronutriente $\mathrm{Mg}$ apresentou resultado diferenciado, com elevação de seus teores do cultivo 'das águas' para o 'da seca' em área com calcário, e com leve redução na área sem calcário.

\subsection{Clima e crescimento das plantas}

Com relação aos parâmetros de clima temperatura do ar (média diária mensal) e precipitação (total mensal), os dados das tabelas 27 e 28 revelam que o cultivo 'das águas', correspondente aos meses de novembro de 1992 a fevereiro de 1993, desenvolveu-se sob temperatura média diária do ar por volta de $23,9^{\circ} \mathrm{C}$, associada ao total de $786,5 \mathrm{~mm}$ de chuva, regularmente precipitados. Tais condições foram adequadamente favoráveis ao amendoim 'das águas'.

Por outro lado, como já esperado, o cultivo 'da seca', que se desenvolveu entre março e julho de 1993, passou por ambiente relativamente mais frio, com temperatura média diária do ar por volta de $21,0^{\circ} \mathrm{C}$ e com o total de $394,0 \mathrm{~mm}$ de chuva, irregularmente precipitados, porém, sem prejudicar drasticamente o amendoim 'da seca'.

Se o cultivo 'das águas', no seu início passou por excedentes hídricos que prejudicaram e atrasaram a emergência das plântulas, o cultivo 'da seca' sofreu com a irregularidade de chuvas.

Tais diferenças explicam, não só para o presente experimento, mas também, para as áreas comerciais, os diferenciais de produtividade observados entre os dois tipos de cultivo. 


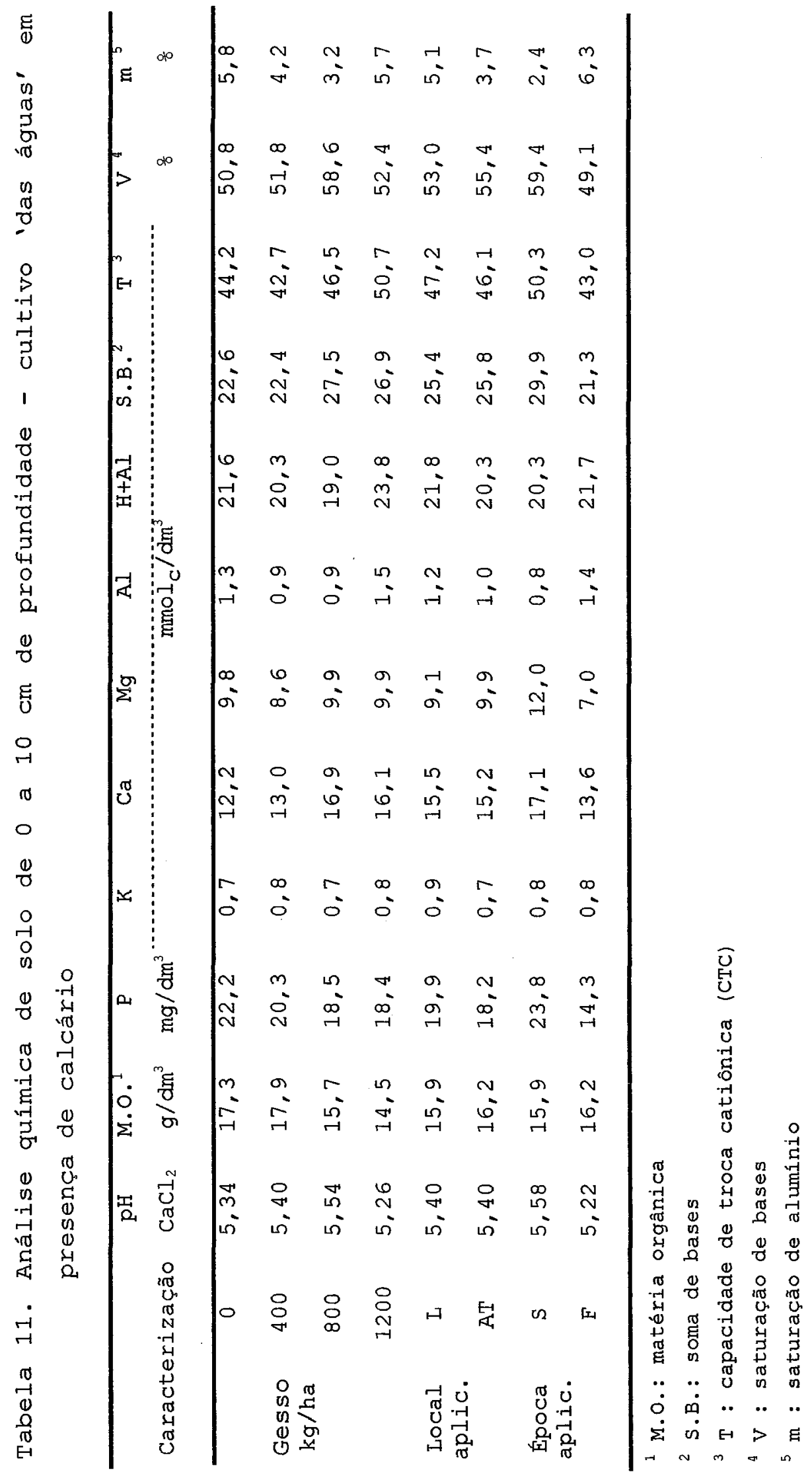




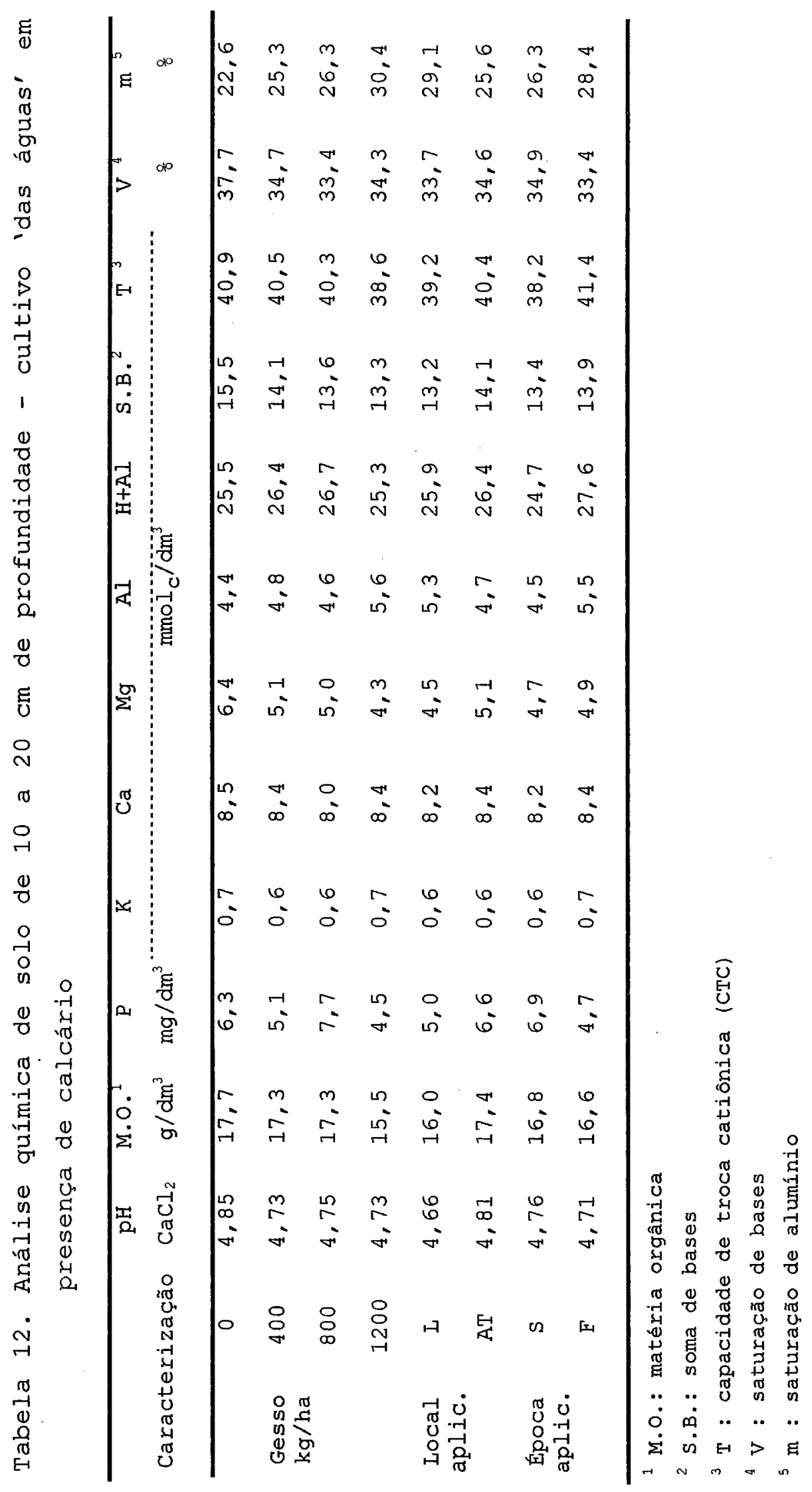




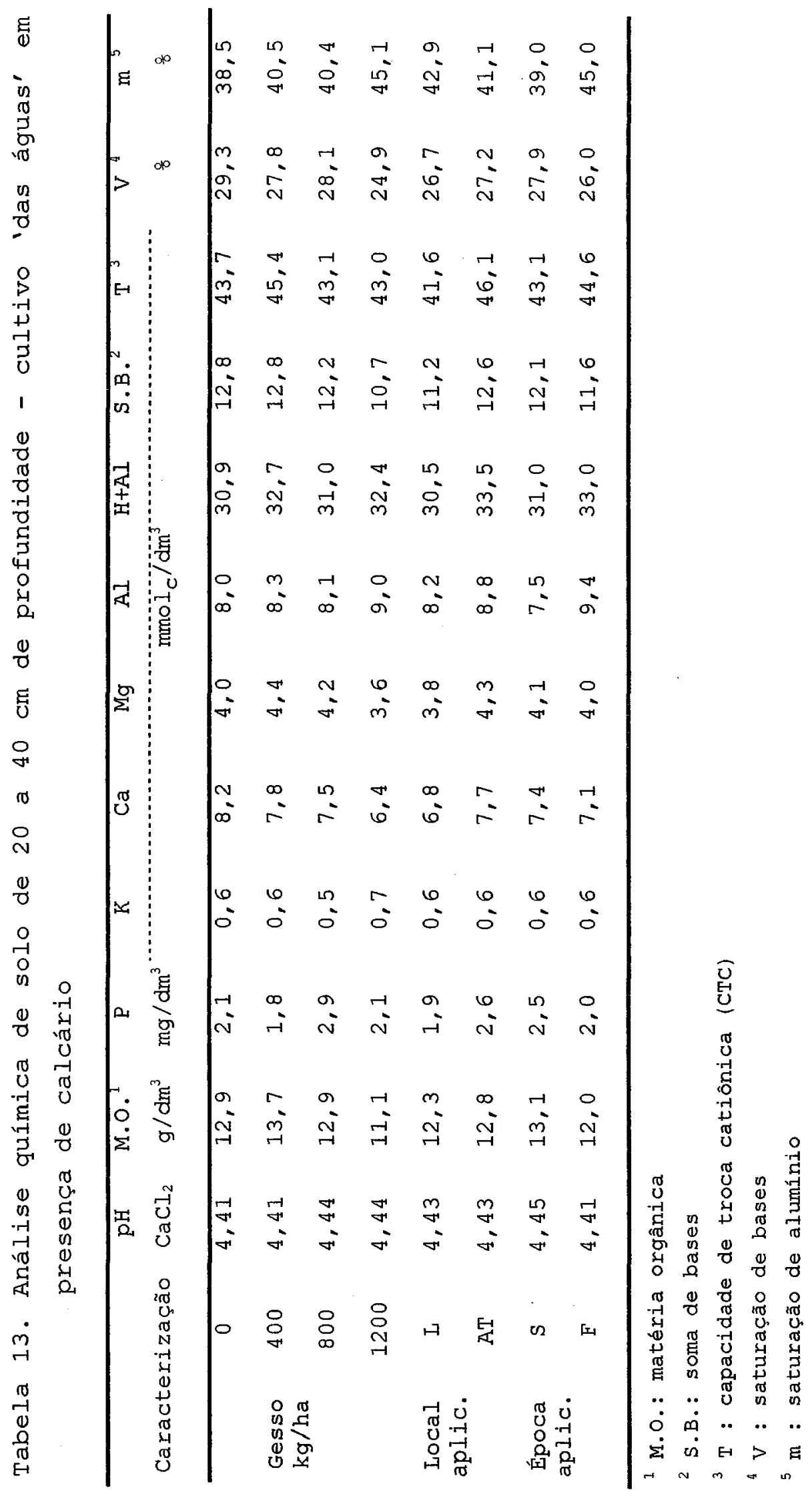




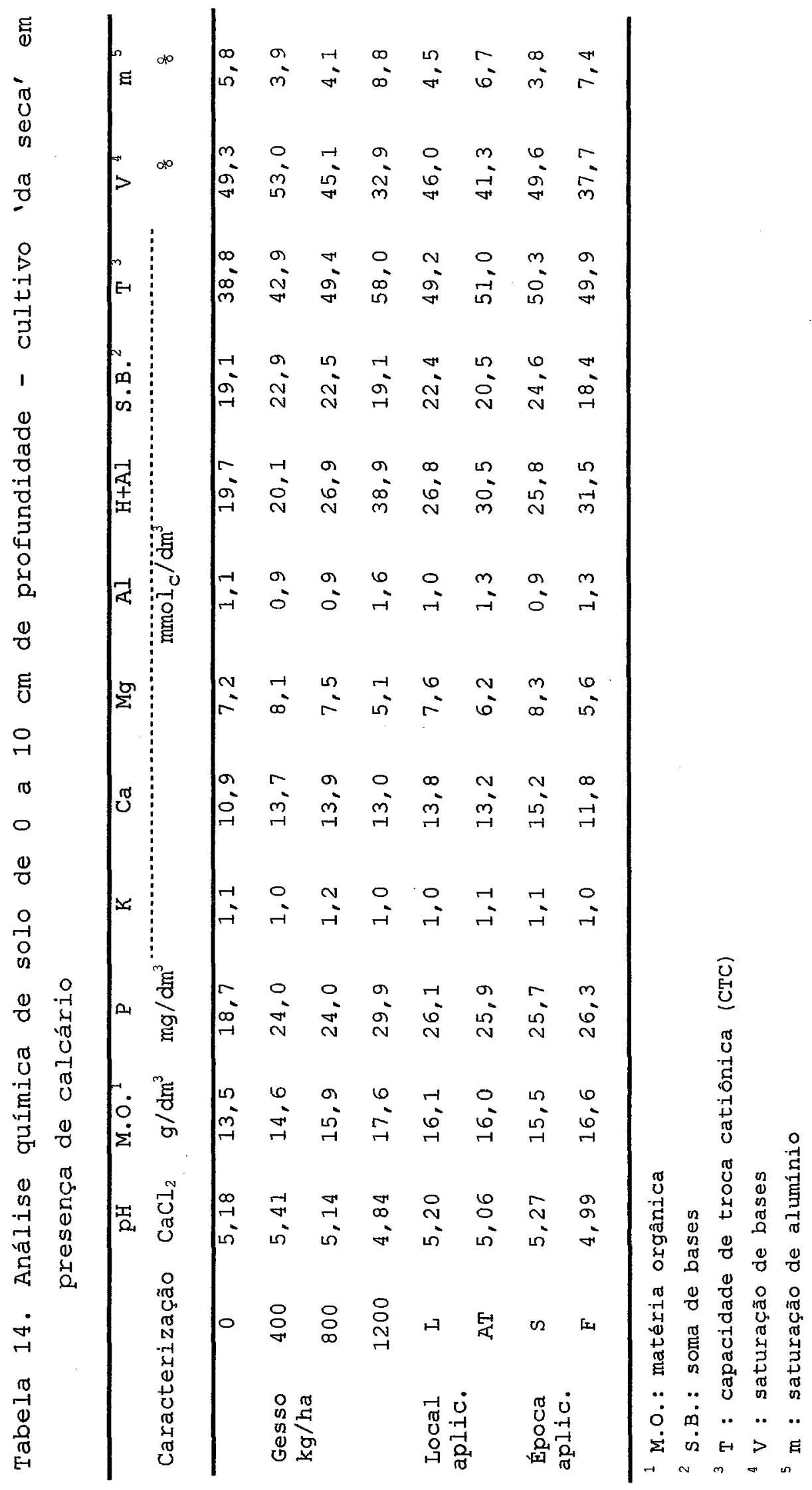




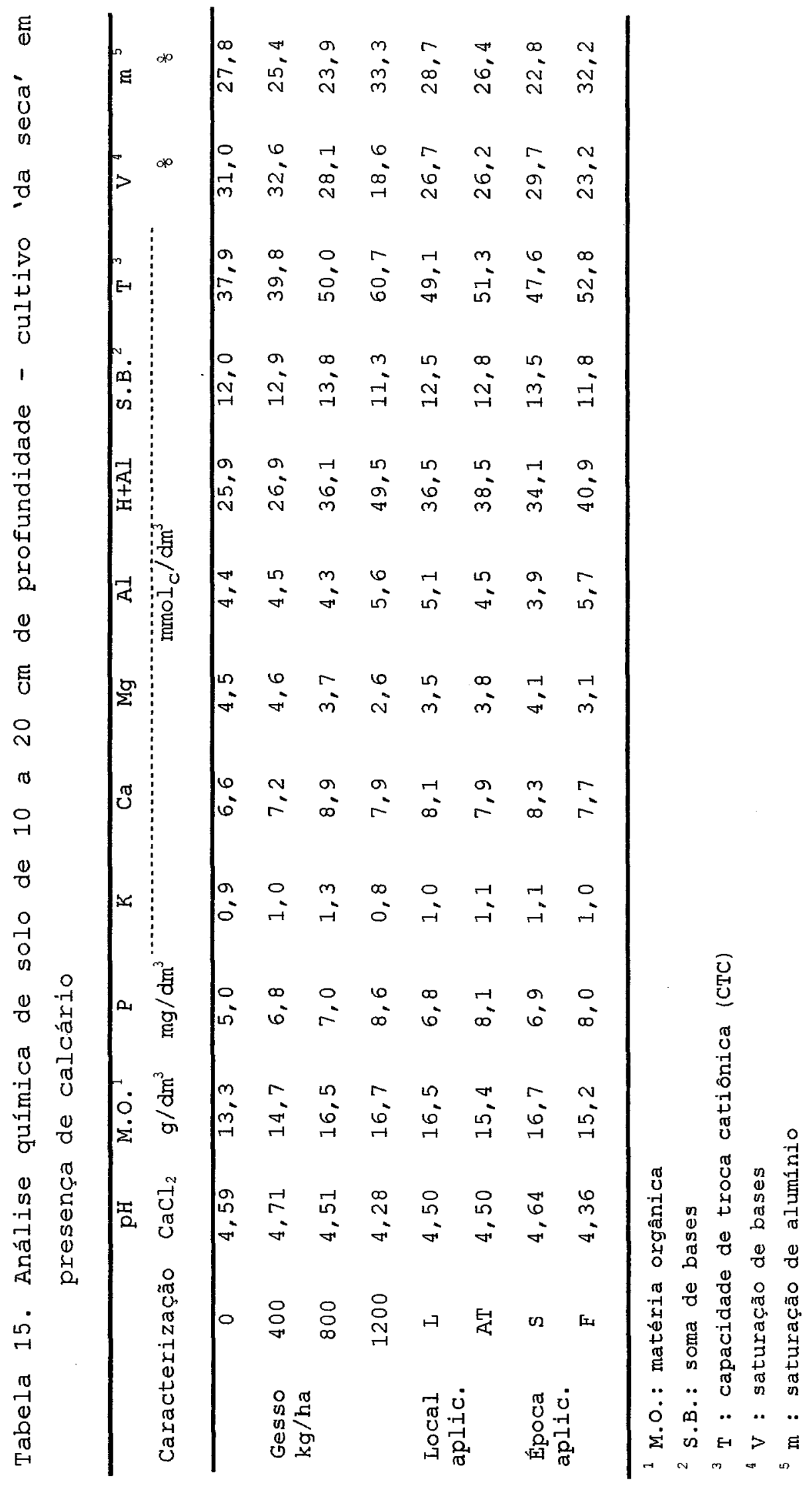




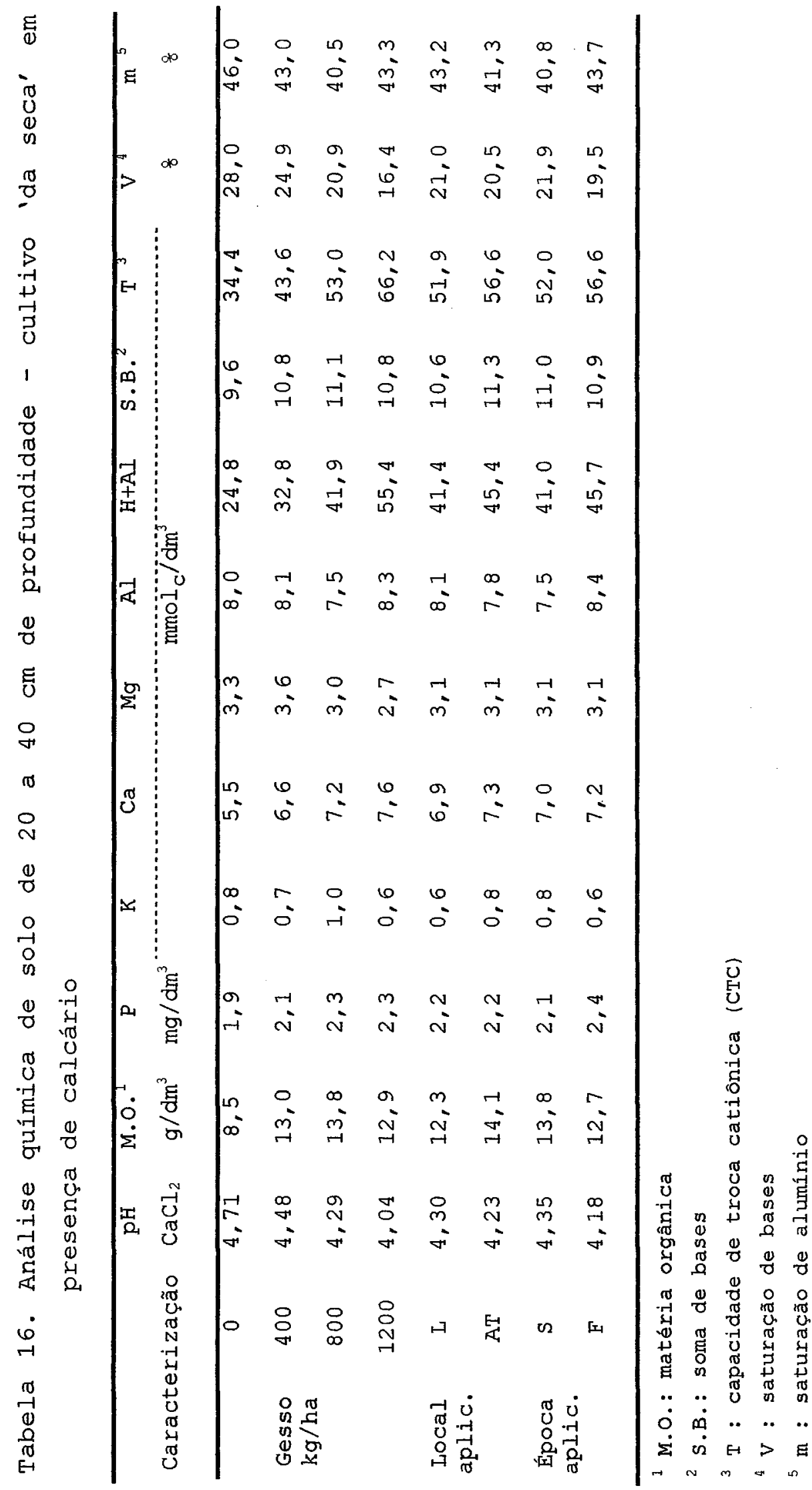




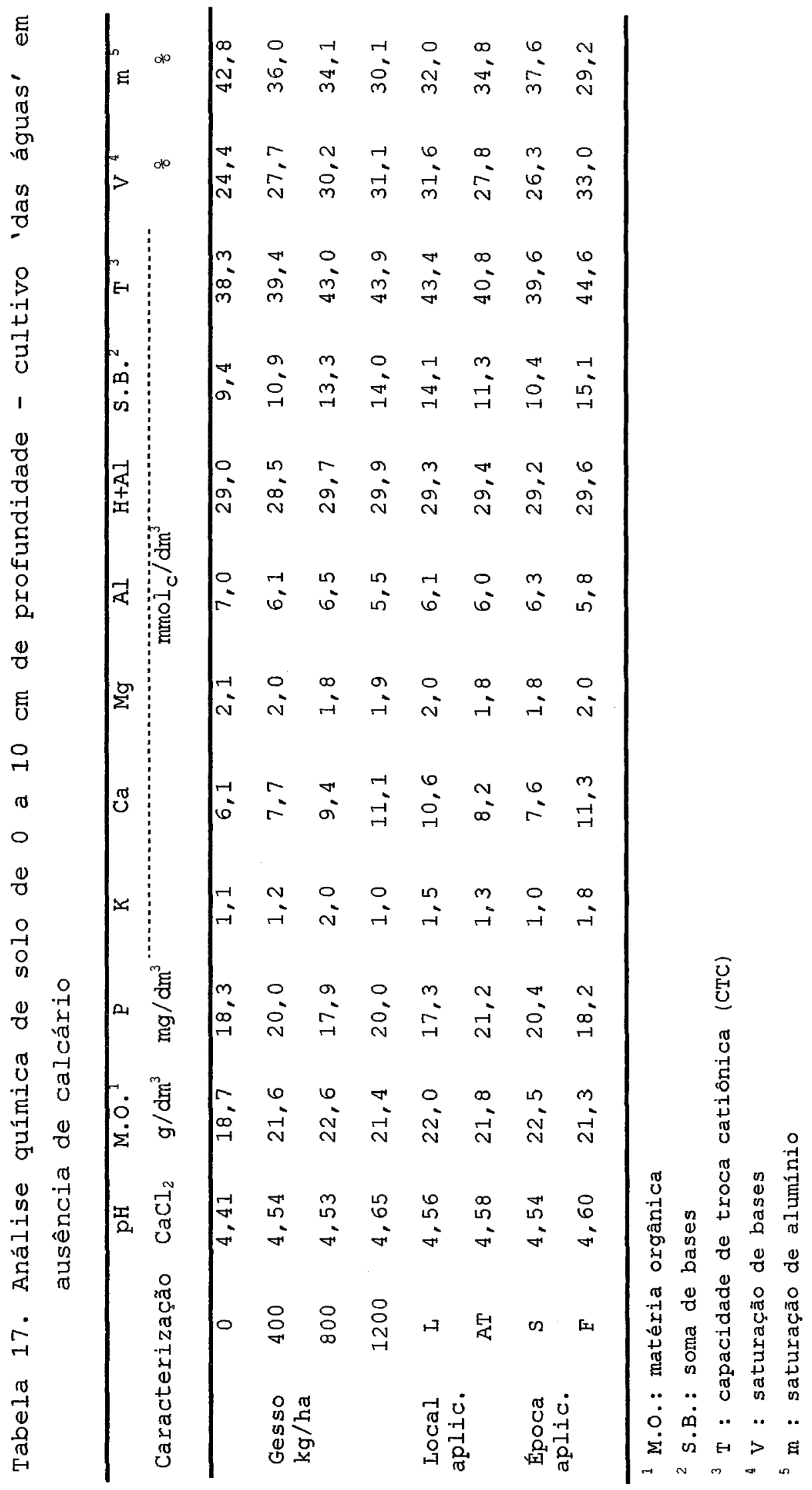




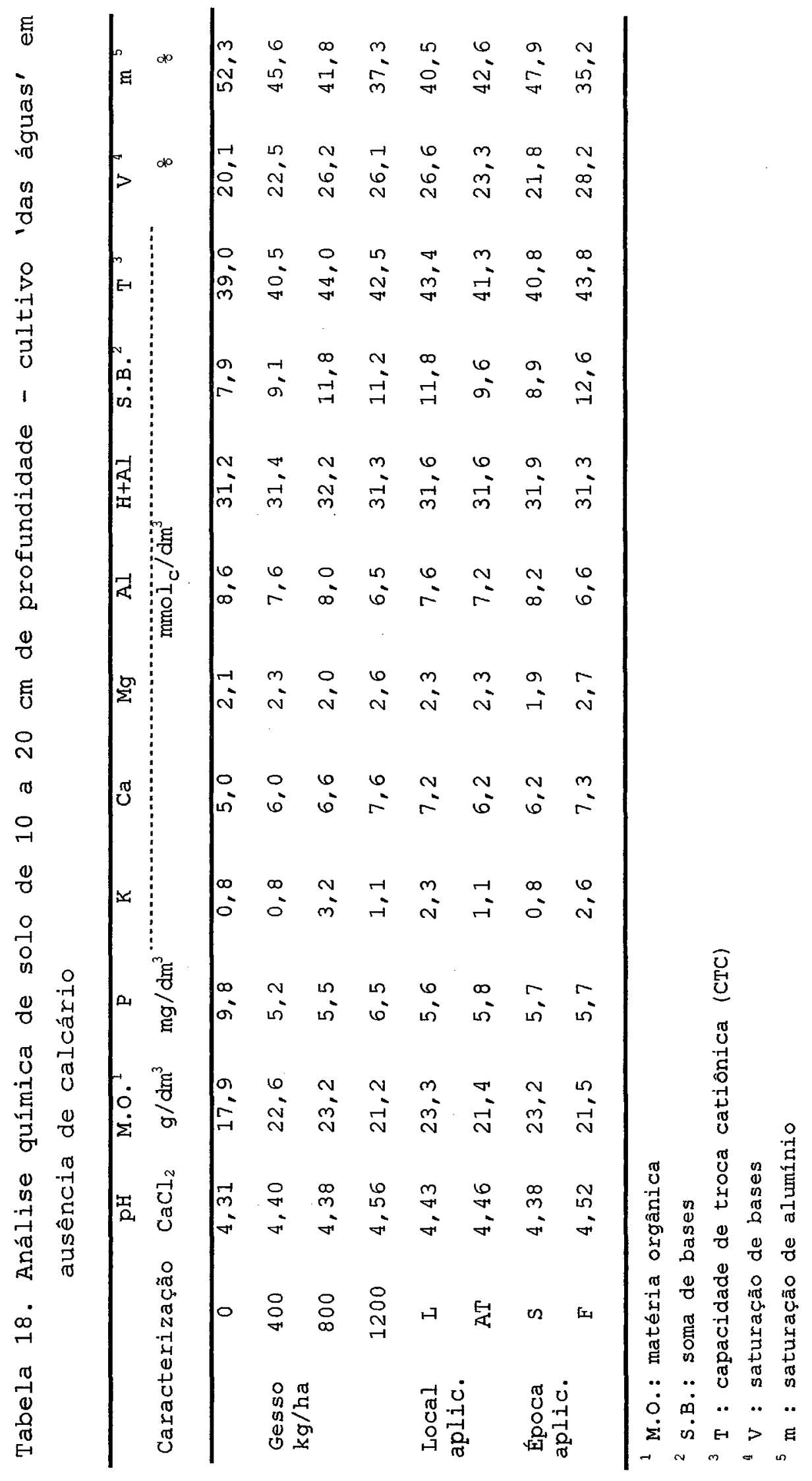




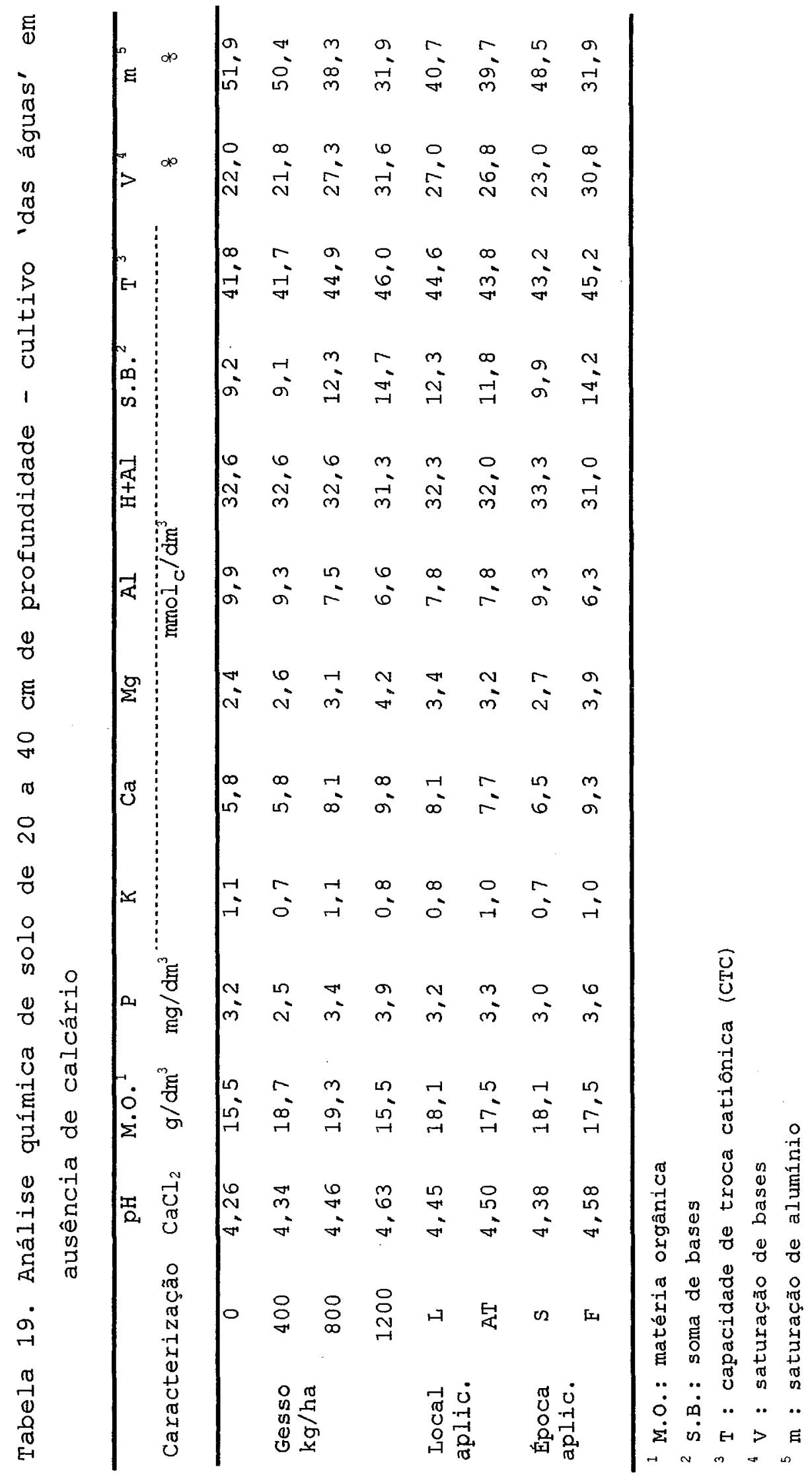









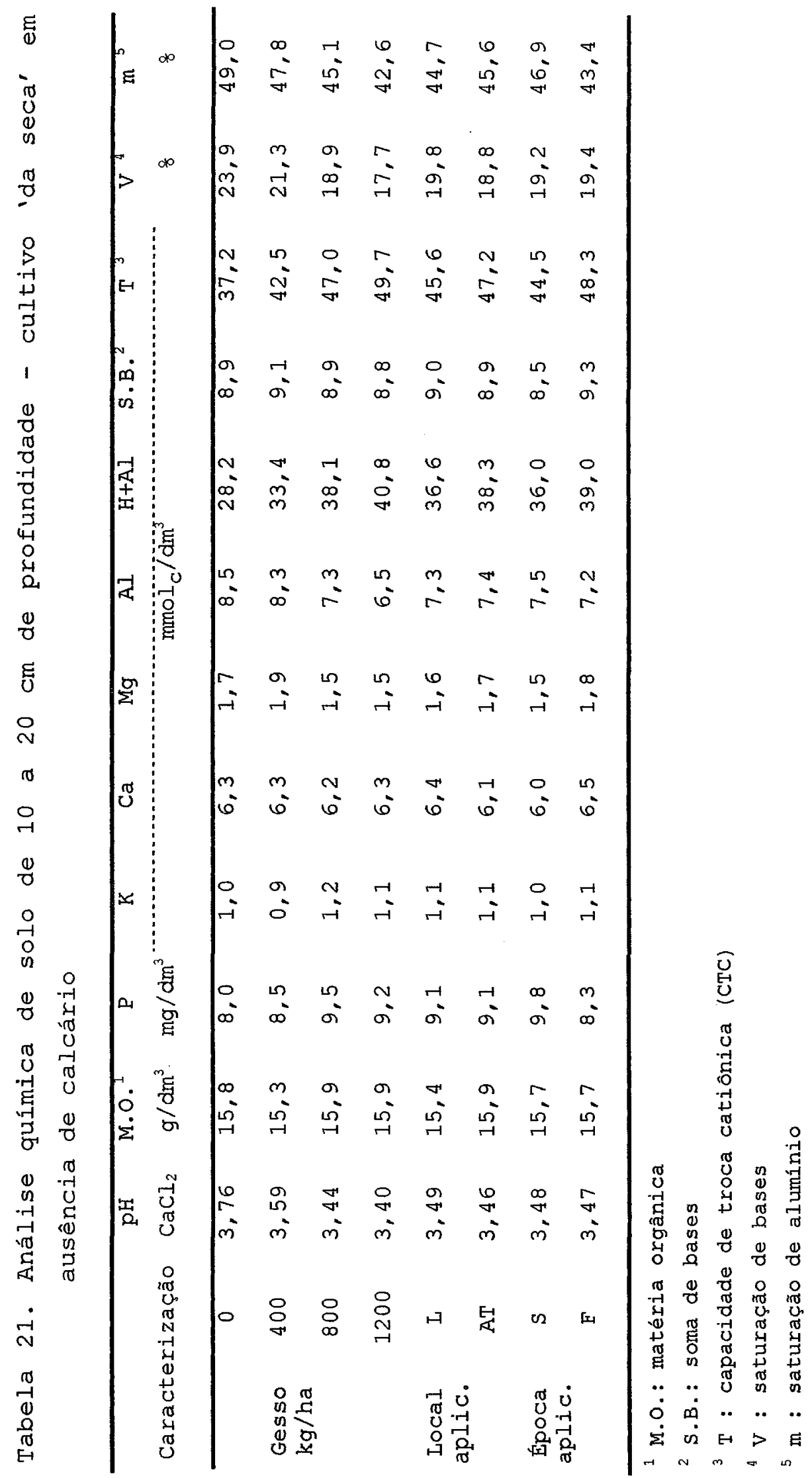




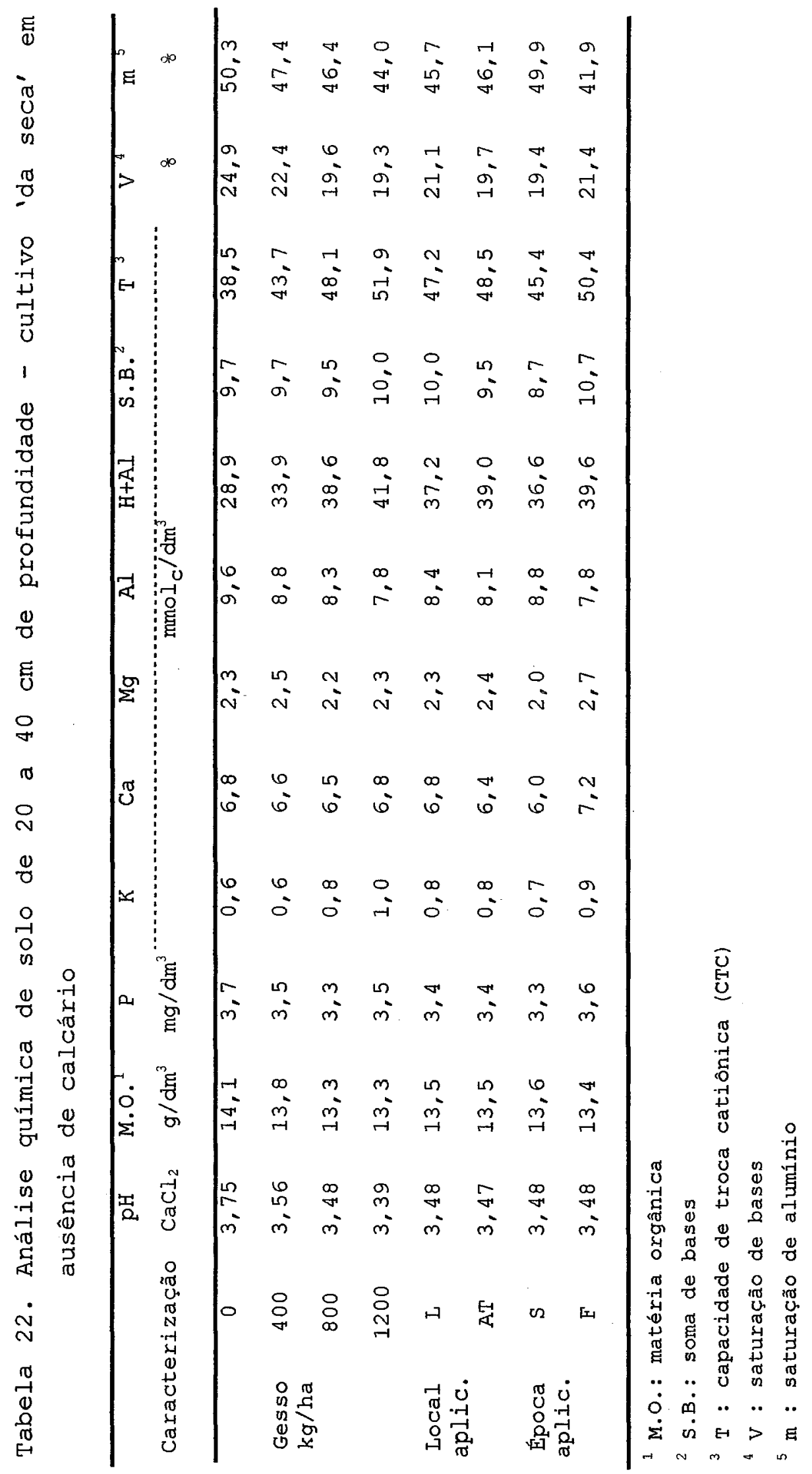




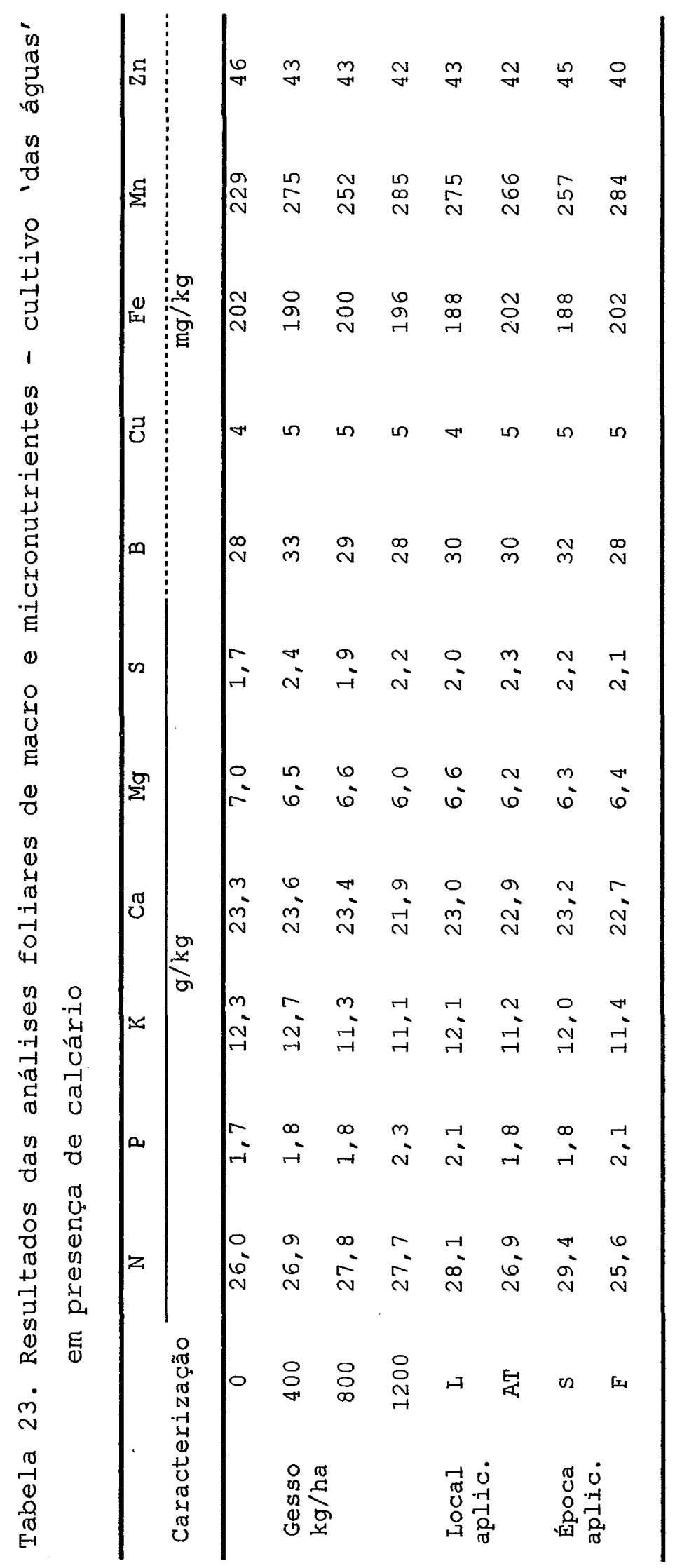




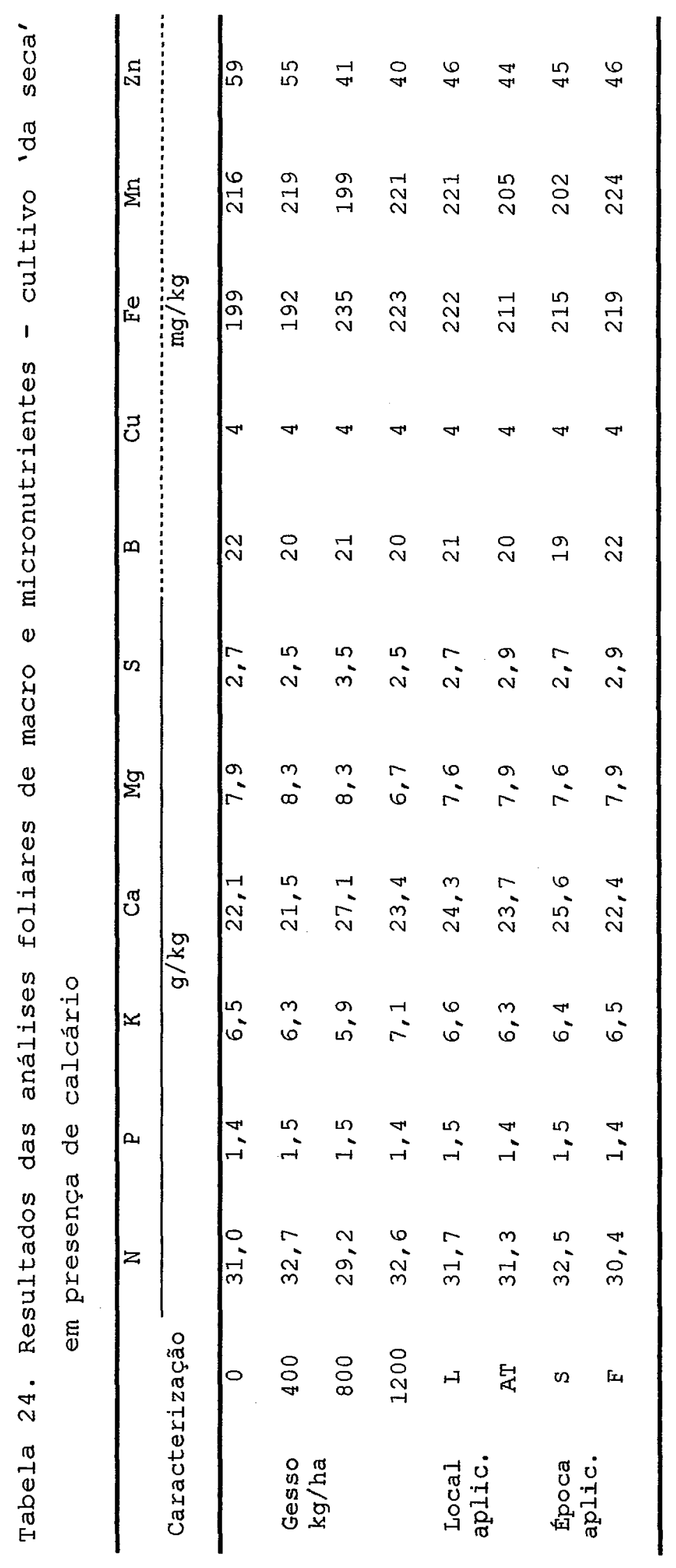




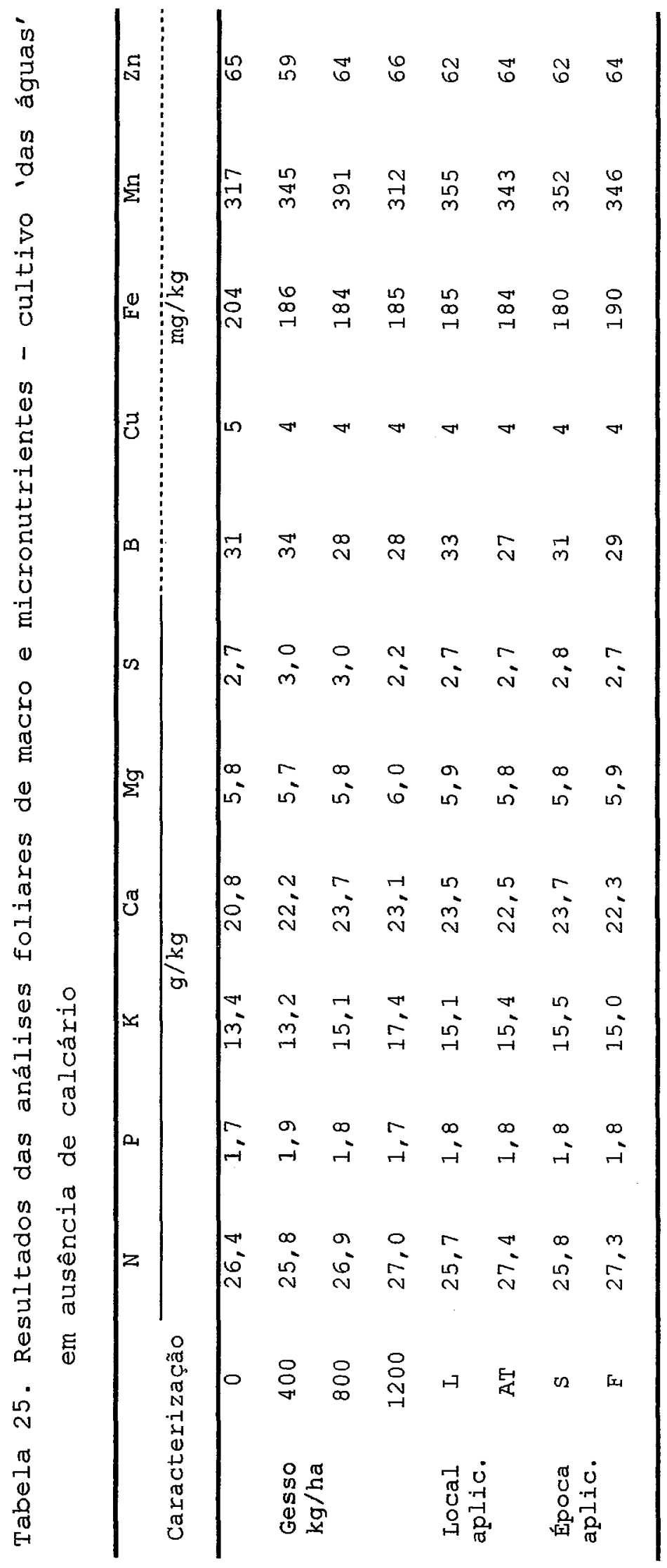




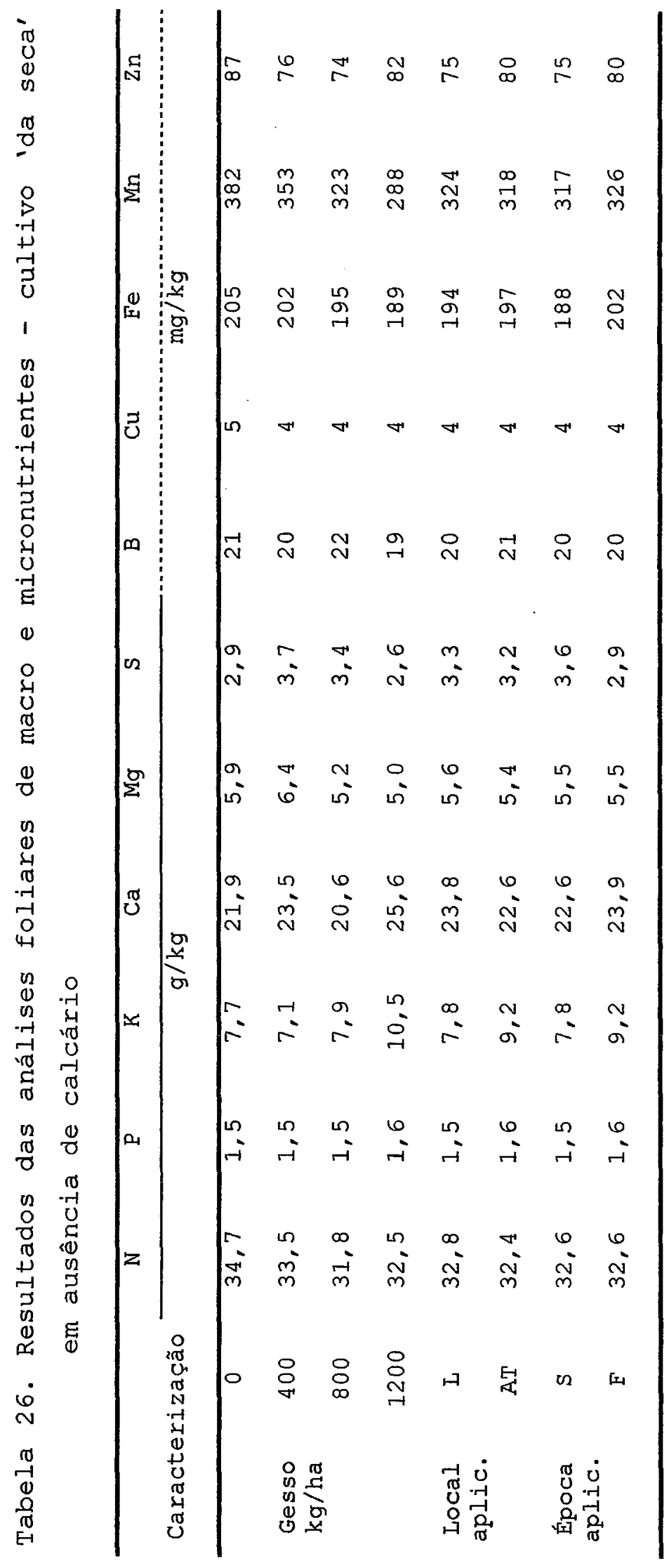


Tabela 27. Preciptação ocorrida durante a condução do experimento em milímetros de altura por período ${ }^{1}$

\begin{tabular}{|c|c|c|c|c|c|c|c|c|c|c|c|}
\hline \multirow[b]{2}{*}{ Período } & \multicolumn{4}{|c|}{1992} & \multicolumn{7}{|c|}{1993} \\
\hline & set & Out & Nov & Dez & Jan & Fev & Mar & Abr & Mai & Jun & Jul \\
\hline 1 a 5 & 6,3 & 53,5 & 78,9 & 32,4 & 7,1 & 30,2 & 0,0 & 4,5 & 30,5 & 13,6 & 0,0 \\
\hline 6 a 10 & 2,2 & 18,4 & 8,5 & 80,4 & 46,2 & 28,2 & 0,0 & 39,5 & 0,0 & 2,0 & 0,0 \\
\hline 11 a 15 & 50,9 & 26,7 & 12,2 & 8,9 & 70,6 & 87,6 & 0,0 & 1,4 & 25,8 & 0,2 & 12,7 \\
\hline 16 a 20 & 9,6 & 9,3 & 12,7 & 17,6 & 9,1 & 58,9 & 39,7 & 0,0 & 0,0 & 31,2 & 0,0 \\
\hline 21 a 25 & 18,3 & 0,0 & 111,5 & 0,0 & 29,2 & 23,7 & 54,7 & 12,3 & 0,0 & 0,0 & 0,0 \\
\hline 26 ao fim & 0,2 & 134,2 & 8,5 & 2,9 & 17,7 & 3,5 & 61,5 & 0,0 & 63,4 & 0,0 & 1,0 \\
\hline Total & 87,5 & 242,1 & 232,3 & 142,2 & 179,9 & 232,1 & 155,9 & 57,7 & 119,7 & 47,0 & 13,7 \\
\hline
\end{tabular}

${ }^{1}$ Dados fornecidos pelo Departamento de Física e Meteorologia - ESALQ/USP

Tabela 28. Temperatura média ocorrida durante a condução do experimento - em graus Celsius por período ${ }^{1}$

1992

1993

Período Set Out Nov Dez Jan Fev Mar Abr Mai Jun Jul

\begin{tabular}{ccccccccccccc}
\hline 1 a 5 & 19,3 & 21,4 & 22,9 & 21,8 & 27,4 & 23,6 & 24,9 & 23,5 & 22,8 & 18,7 & 22,0 \\
6 a 10 & 18,1 & 19,8 & 21,4 & 23,8 & 24,8 & 24,8 & 26,1 & 23,6 & 20,8 & 20,6 & 19,1 \\
11 a 15 & 17,8 & 22,4 & 25,2 & 22,0 & 23,7 & 24,3 & 25,5 & 23,6 & 20,1 & 17,2 & 17,9 \\
16 & a 20 & 20,6 & 23,6 & 23,6 & 24,2 & 25,2 & 23,4 & 24,5 & 23,8 & 18,9 & 16,3 & 19,1 \\
21 a 25 & 23,0 & 21,8 & 23,4 & 25,4 & 25,0 & 22,8 & 23,5 & 23,0 & 17,7 & 17,7 & 18,9 \\
26 ao fim & 18,6 & 23,9 & 21,7 & 23,8 & 25,8 & 24,0 & 24,1 & 22,2 & 18,1 & 18,6 & 17,8 \\
\hline & Média & 19,6 & 22,2 & 23,0 & 23,5 & 25,3 & 23,8 & 24,7 & 23,3 & 19,7 & 18,2 & 19,1 \\
\hline
\end{tabular}

${ }^{1}$ Dados fornecidos pelo Departamento de Física e Meteorologia - ESALQ/USP 


\section{CONCLUSÕES}

- Em ausência de calcário, a adubação de semeadura com fósforo e potássio não deve ser negligenciada, principalmente, quando se visa o cultivo do amendoim 'das águas', seguido pelo 'da seca';

- A adubação do amendoim 'da seca' com fósforo e potássio, proporciona maior produtividade de vagens;

- o uso do enxofre elementar na adubação de semeadura prejudica a emergência, o estabelecimento inicial da cultura e o desempenho dos componentes da produção de amendoim;

- Para o cultivo 'da seca', a presença de gesso agrícola residual proveniente de sua aplicação no amendoim 'das águas', proporciona melhor desempenho dos componentes da produção e da própria produção de amendoim;

- Tanto em presença, como em ausência de calcário, não foram observadas diferenças significativas entre a aplicação de gesso agrícola localizada e a em área total, em ambos os cultivos;

- Em presença de calcário, a aplicação de gesso agrícola por ocasião do florescimento, tende a ser melhor que à aplicação na semeadura, em ambos os cultivos;

- Em ausência de calcário, não foi observada, diferença entre as épocas de aplicação de gesso agrícola, em ambos os cultivos. 
A N E X O S 


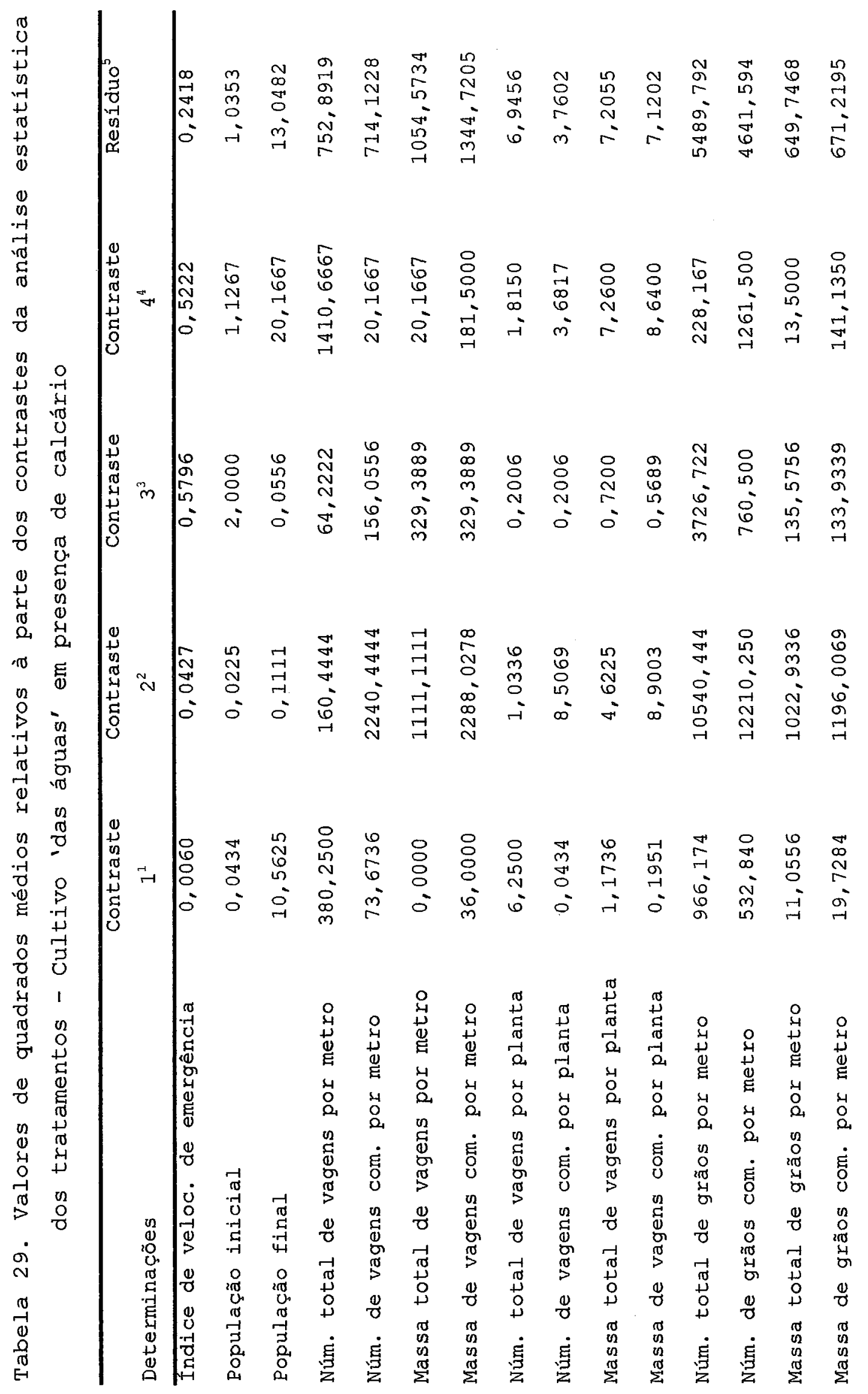




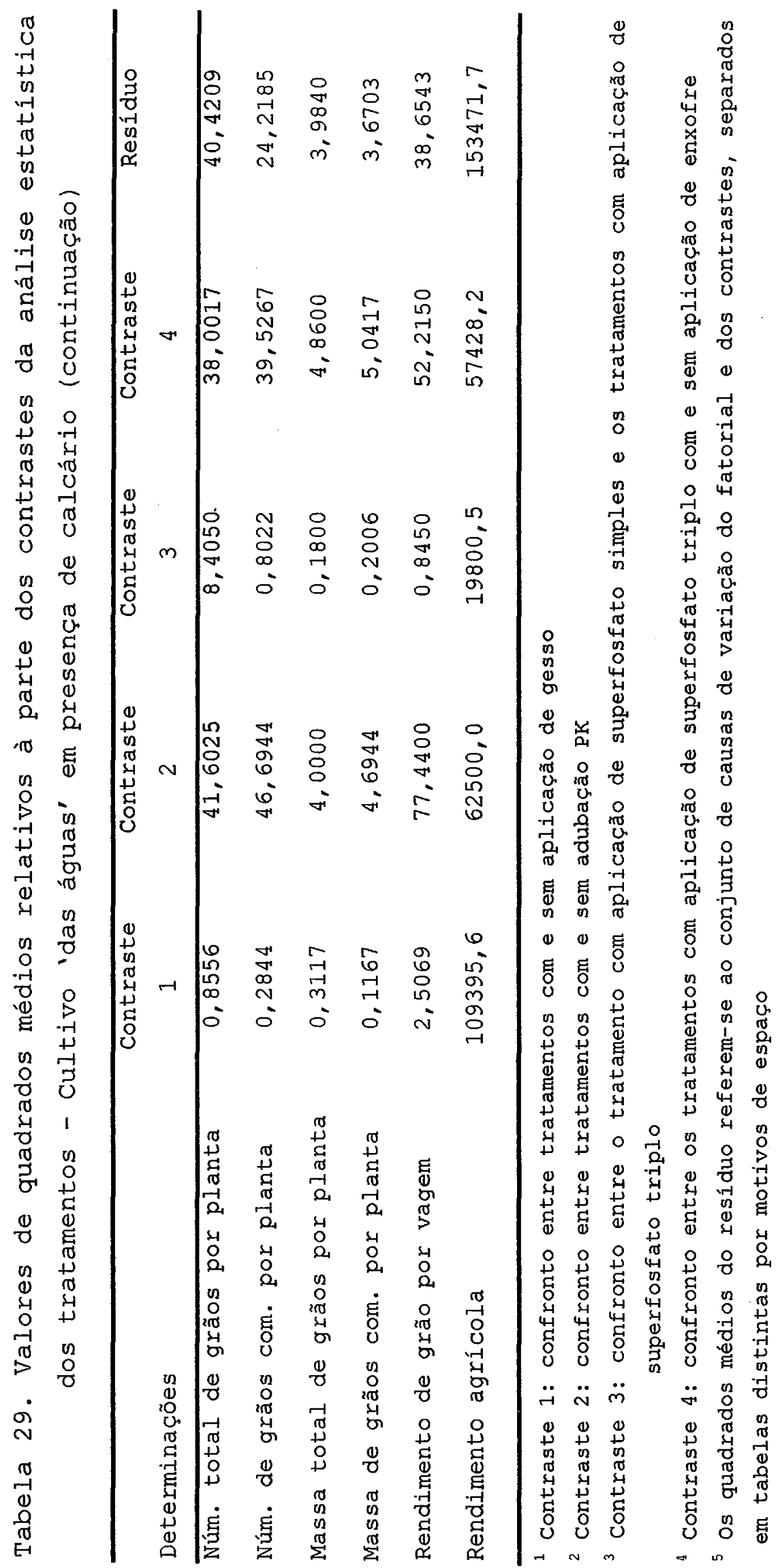




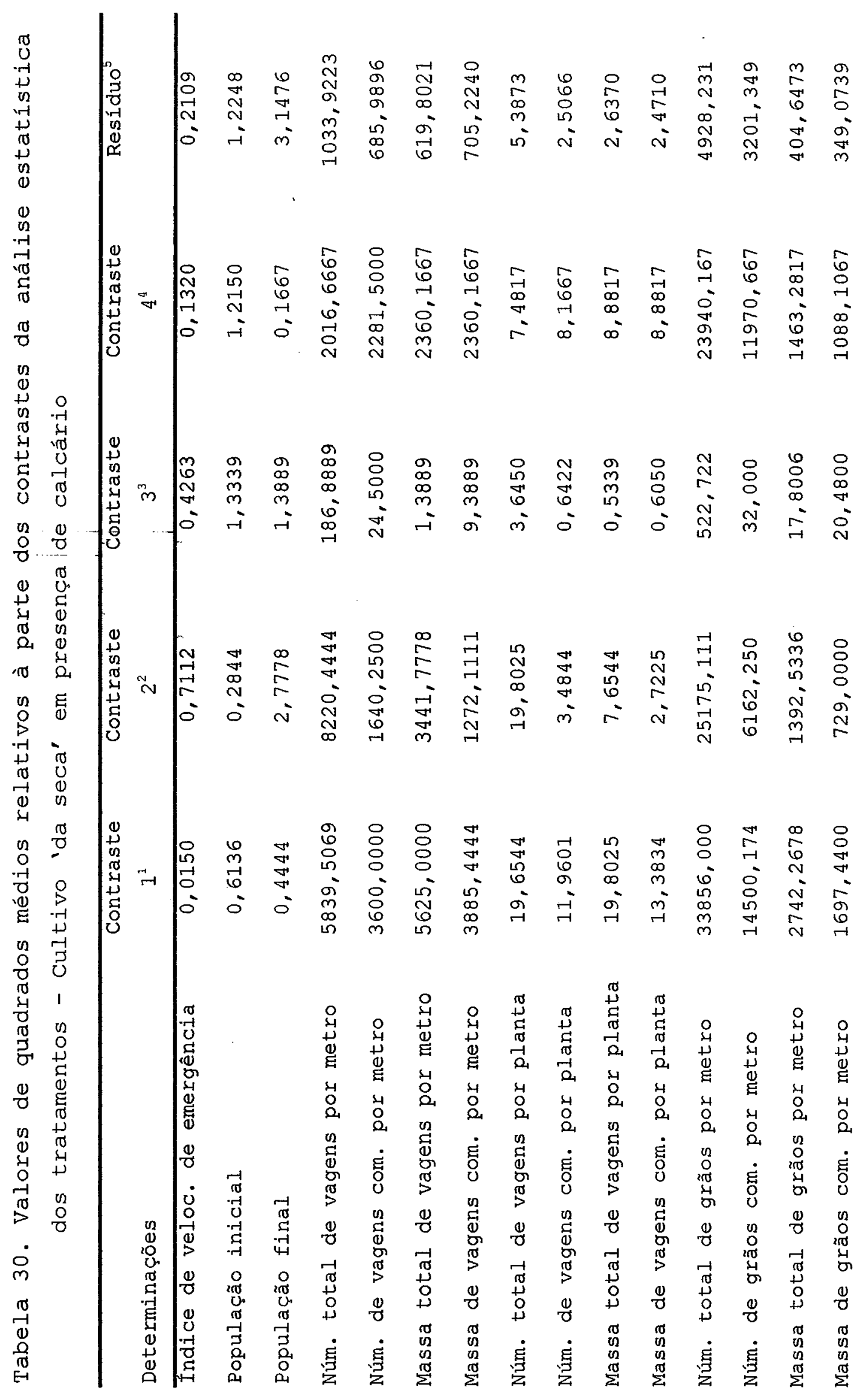




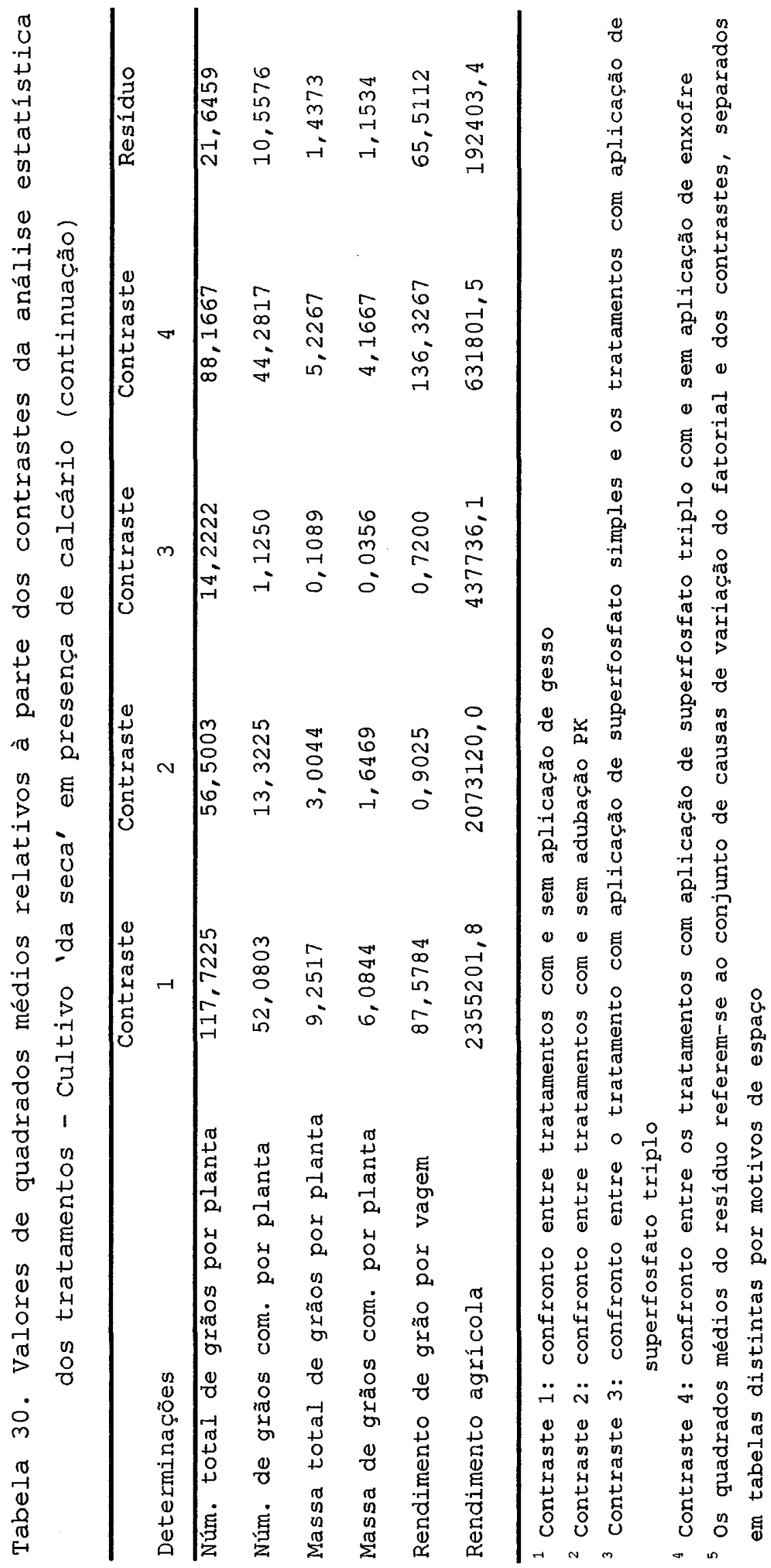




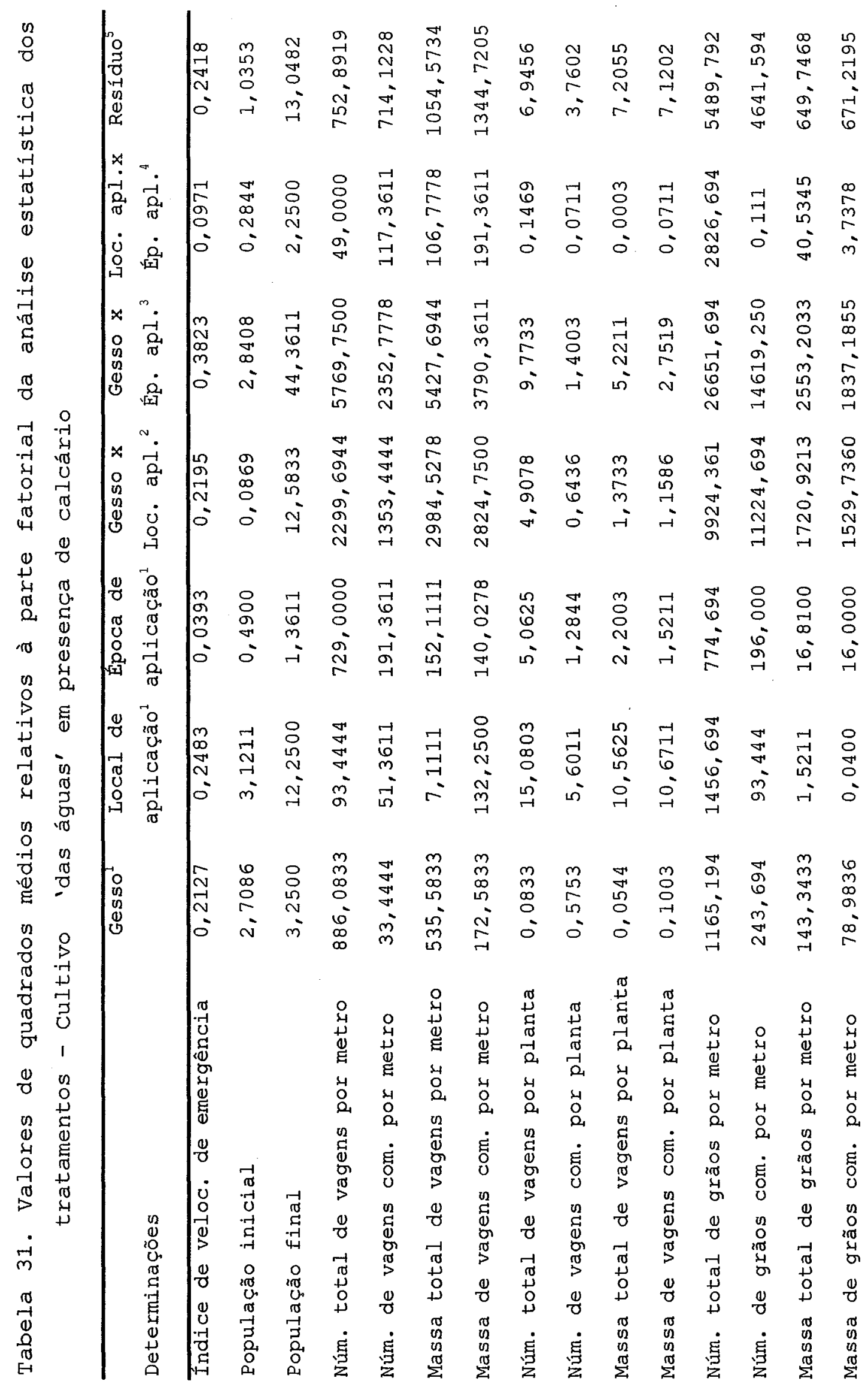




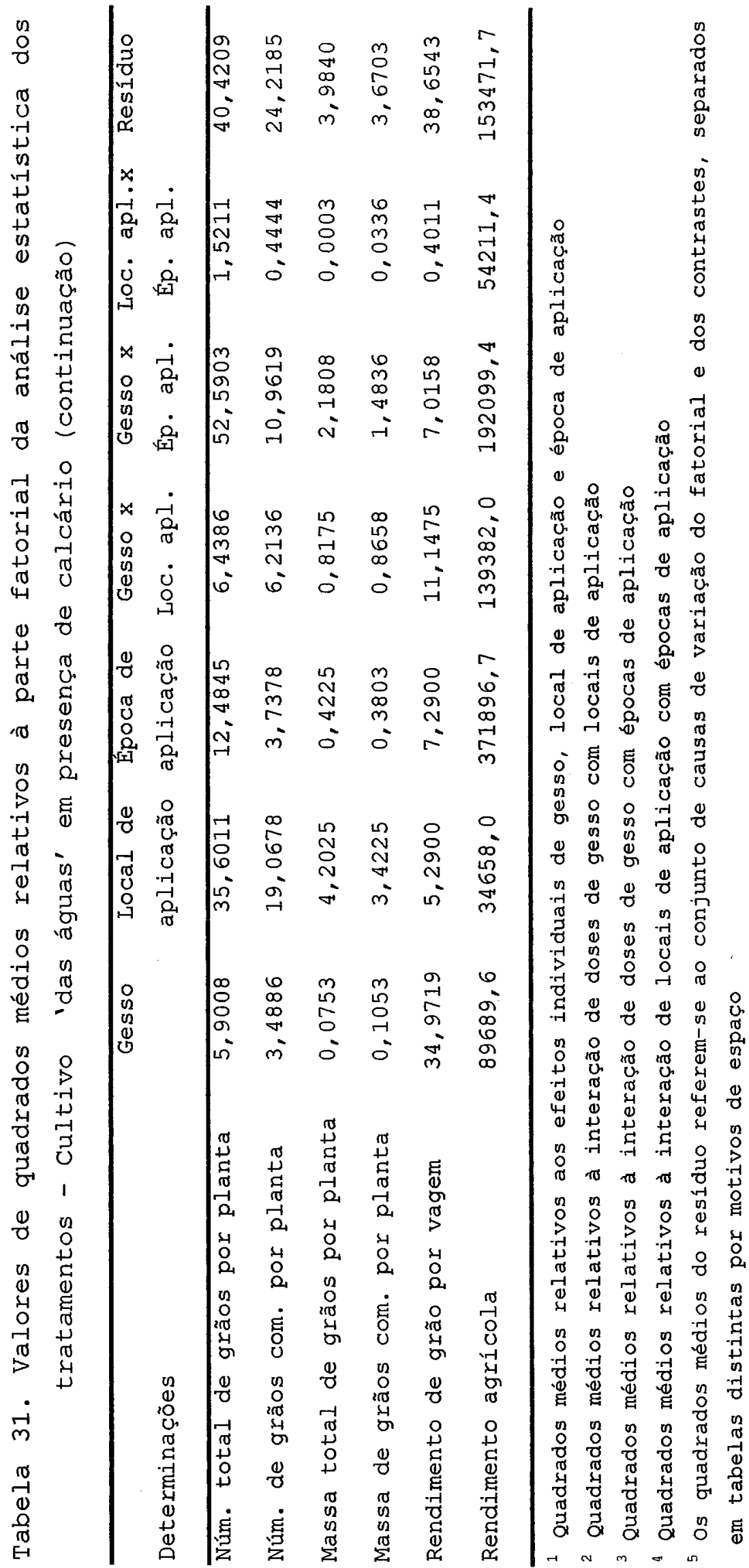




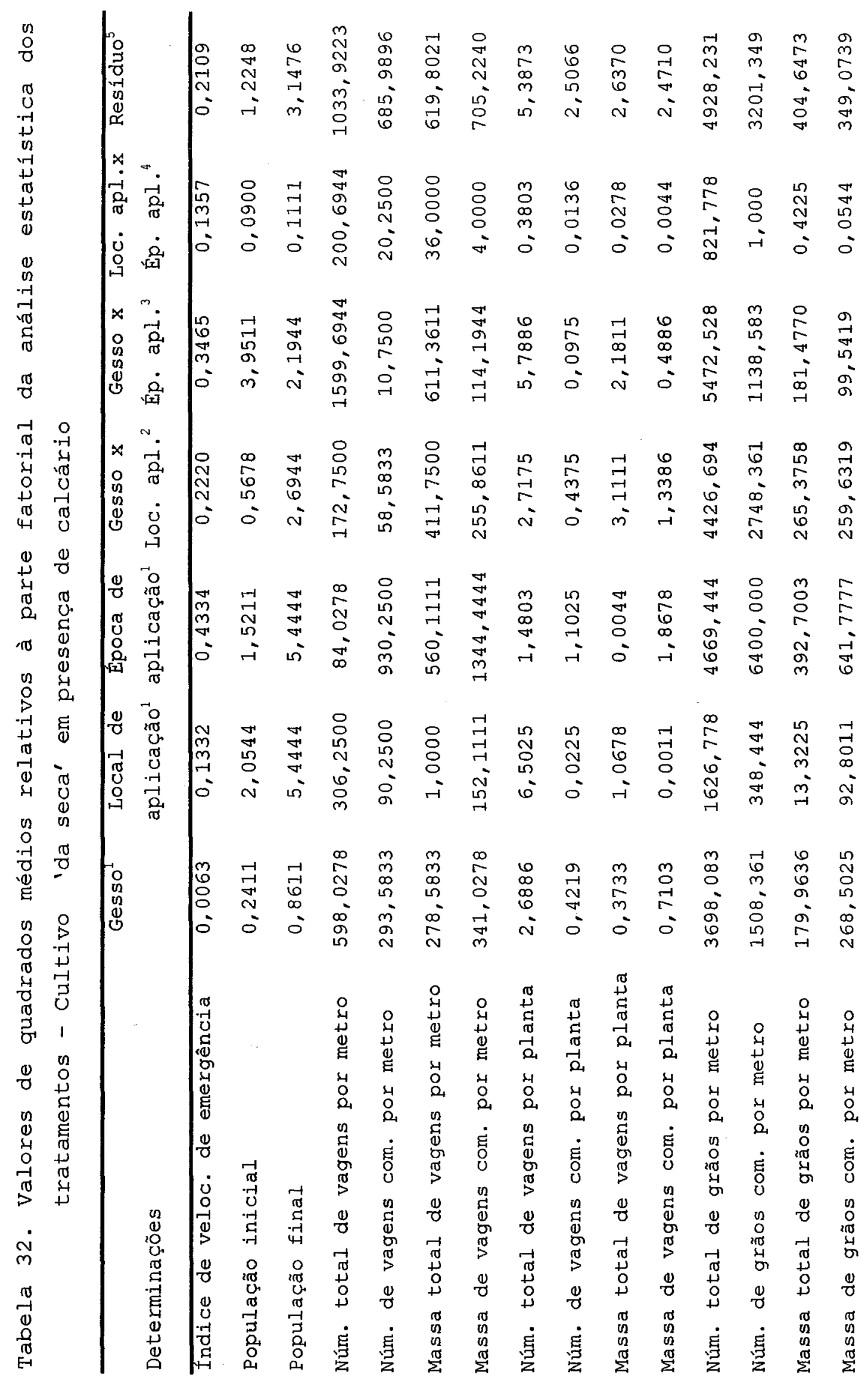




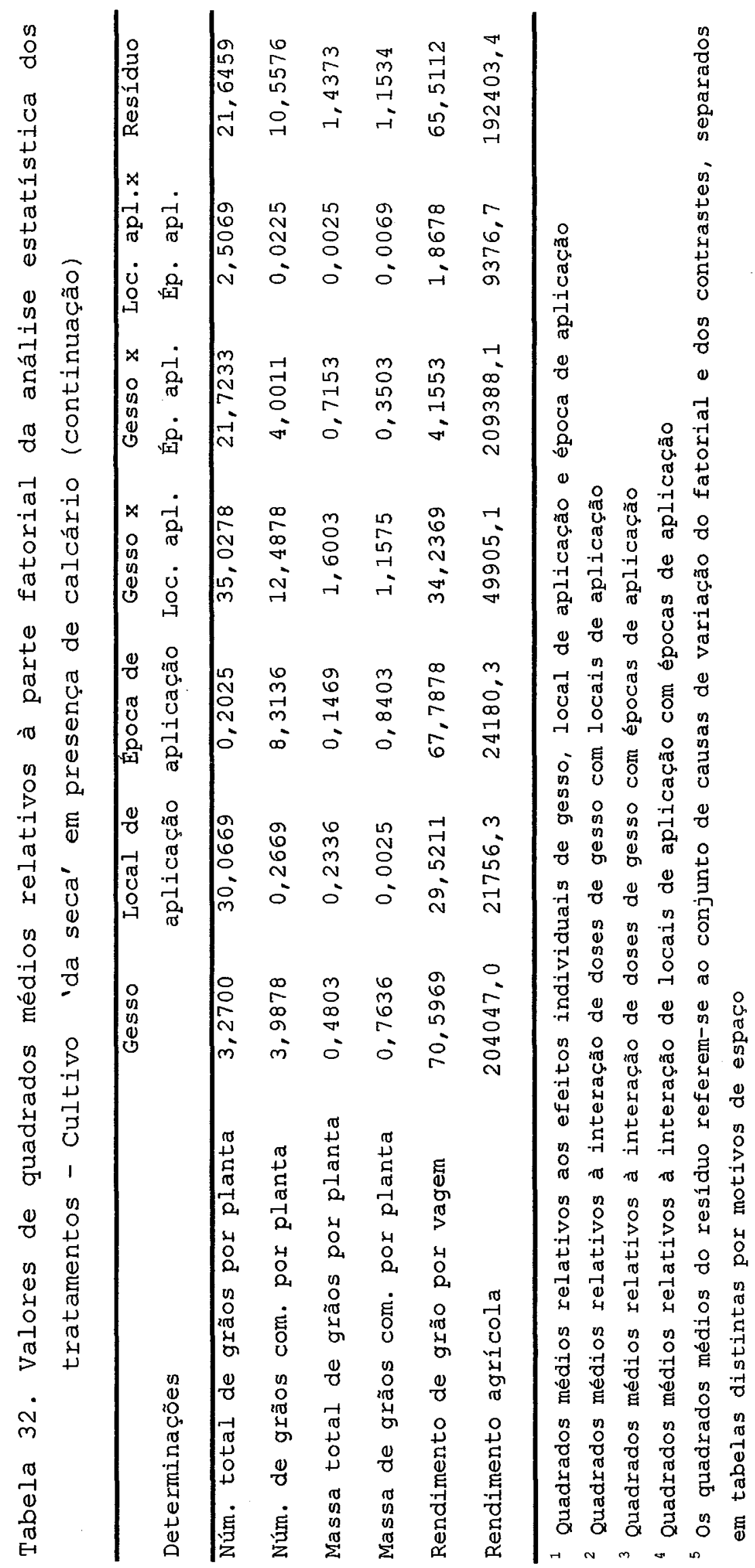




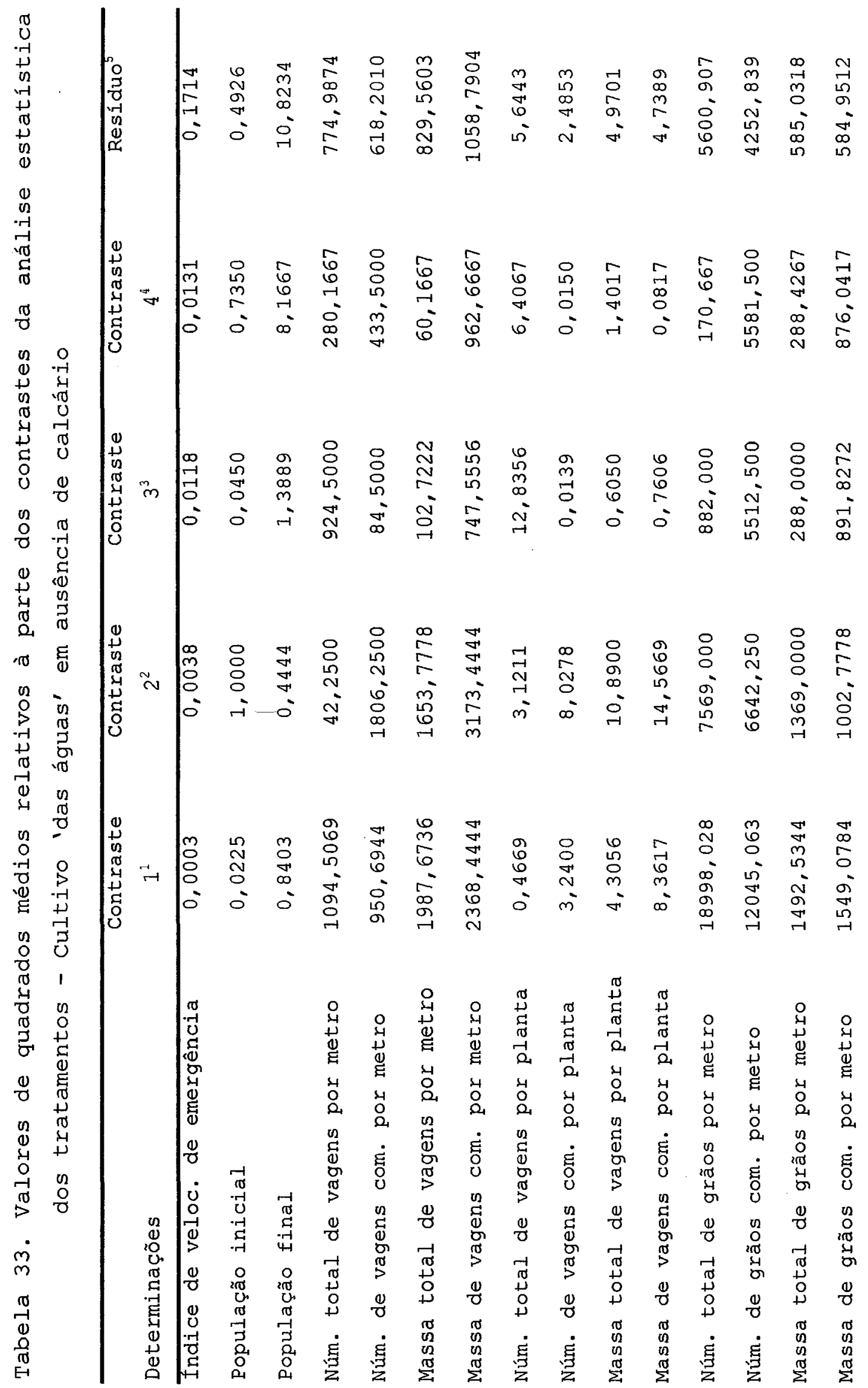




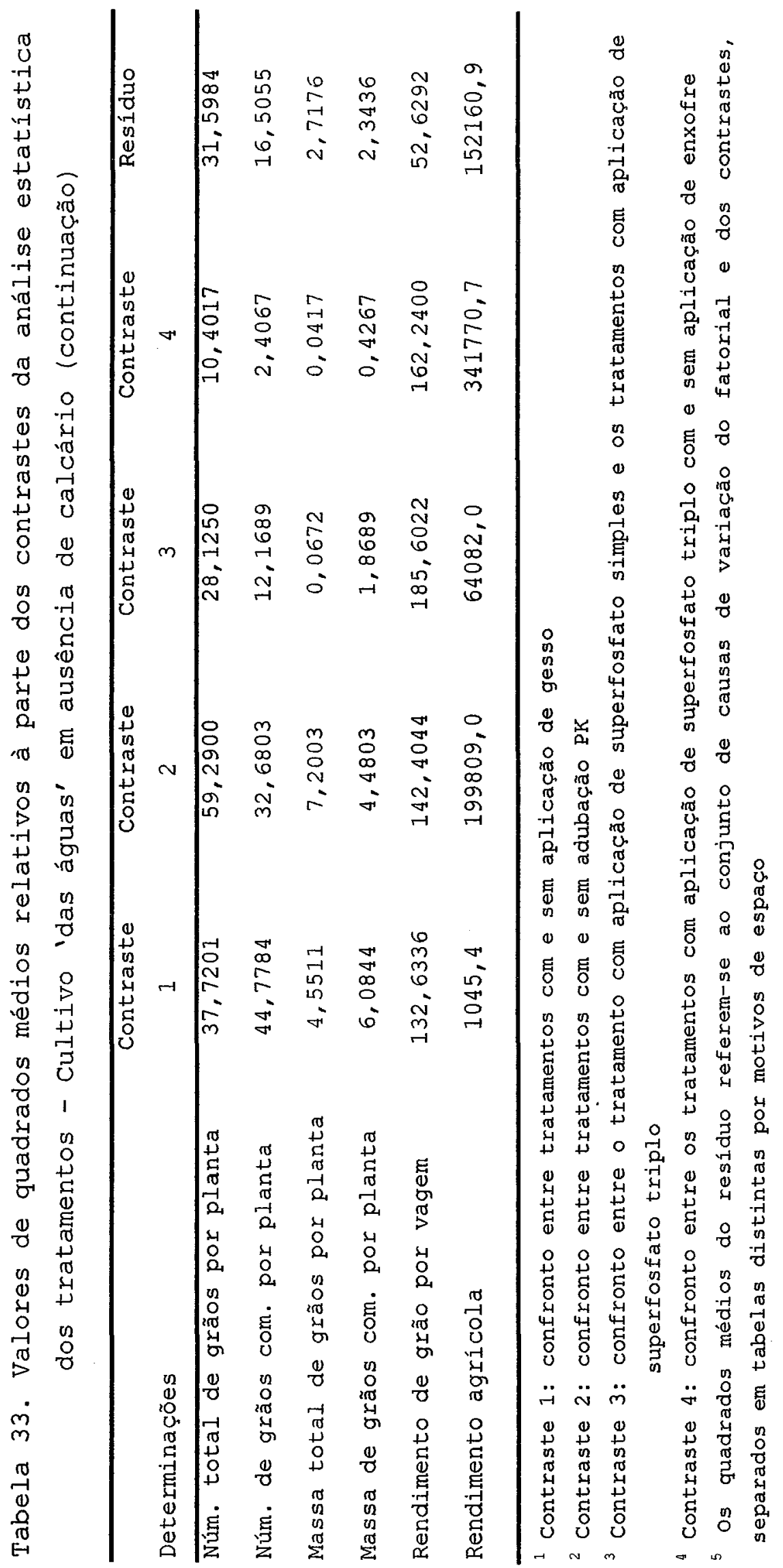




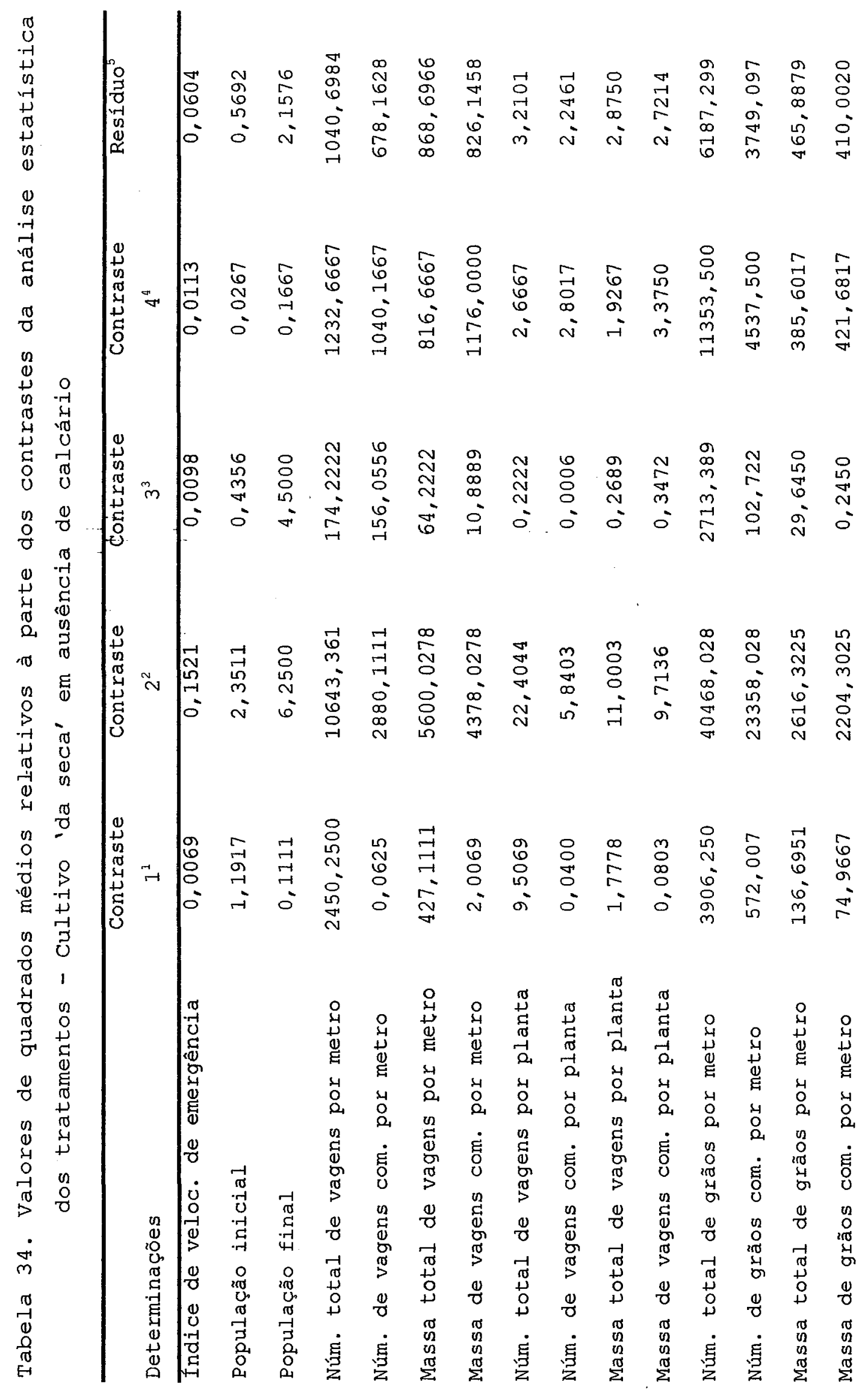




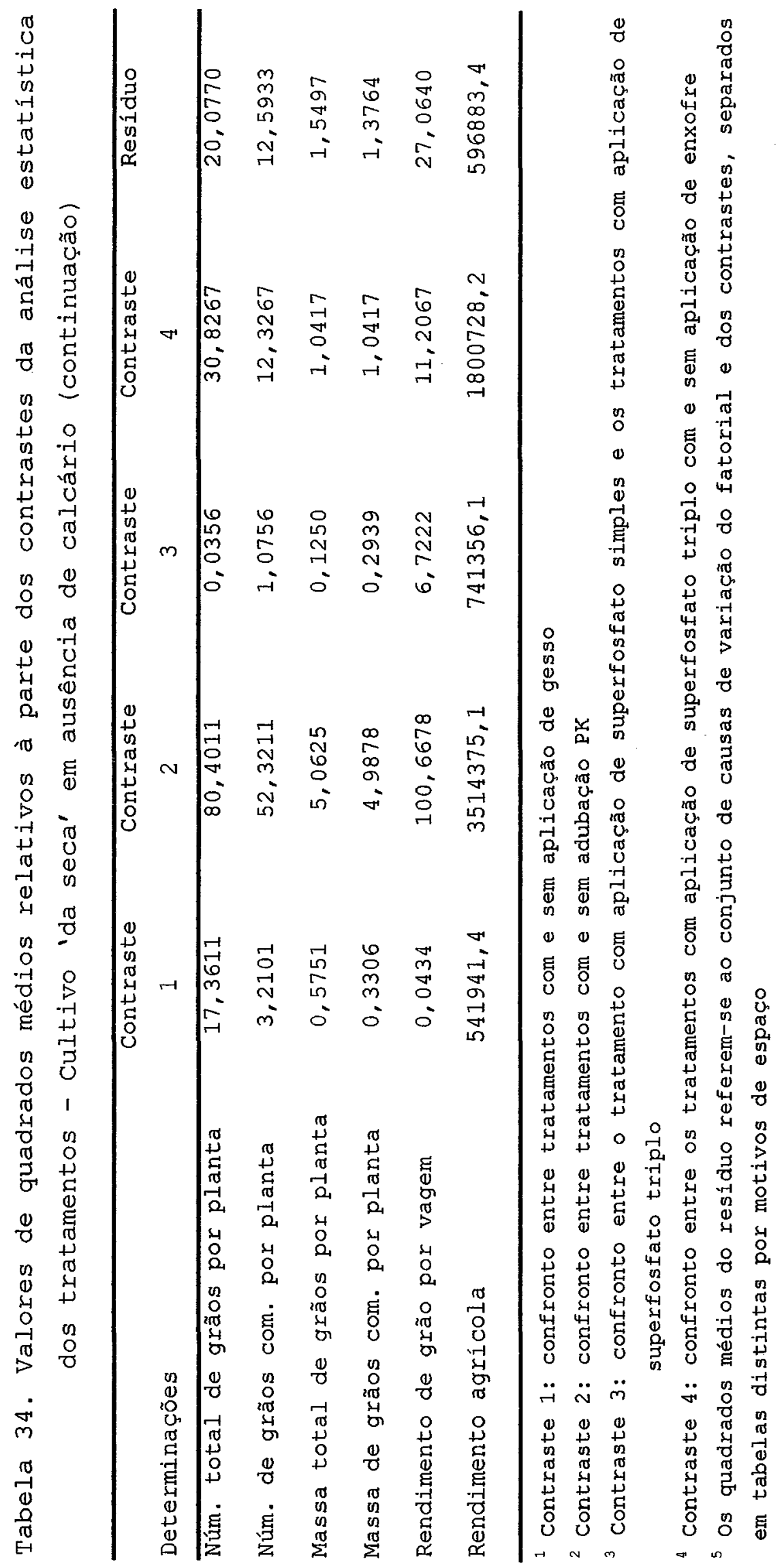




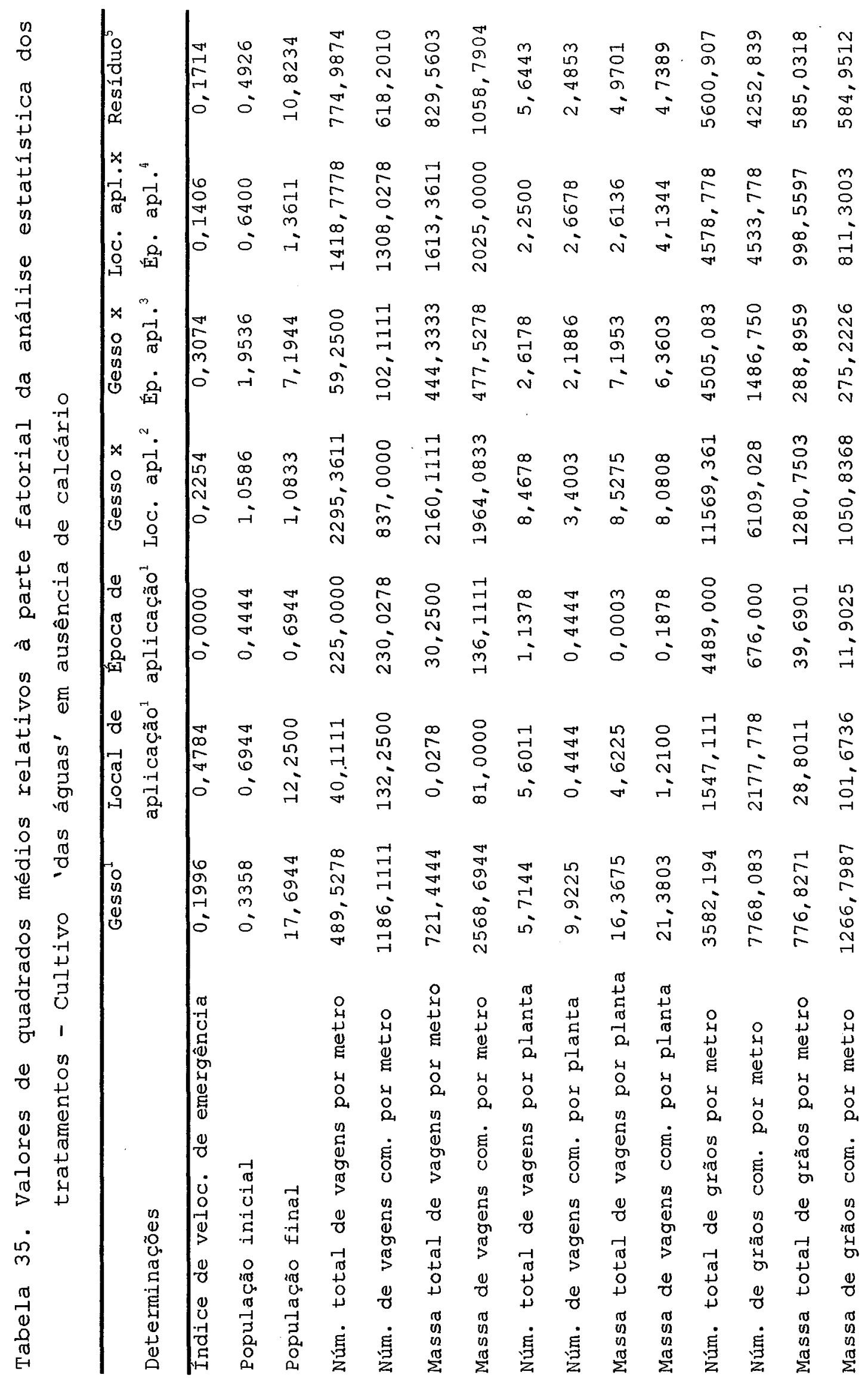




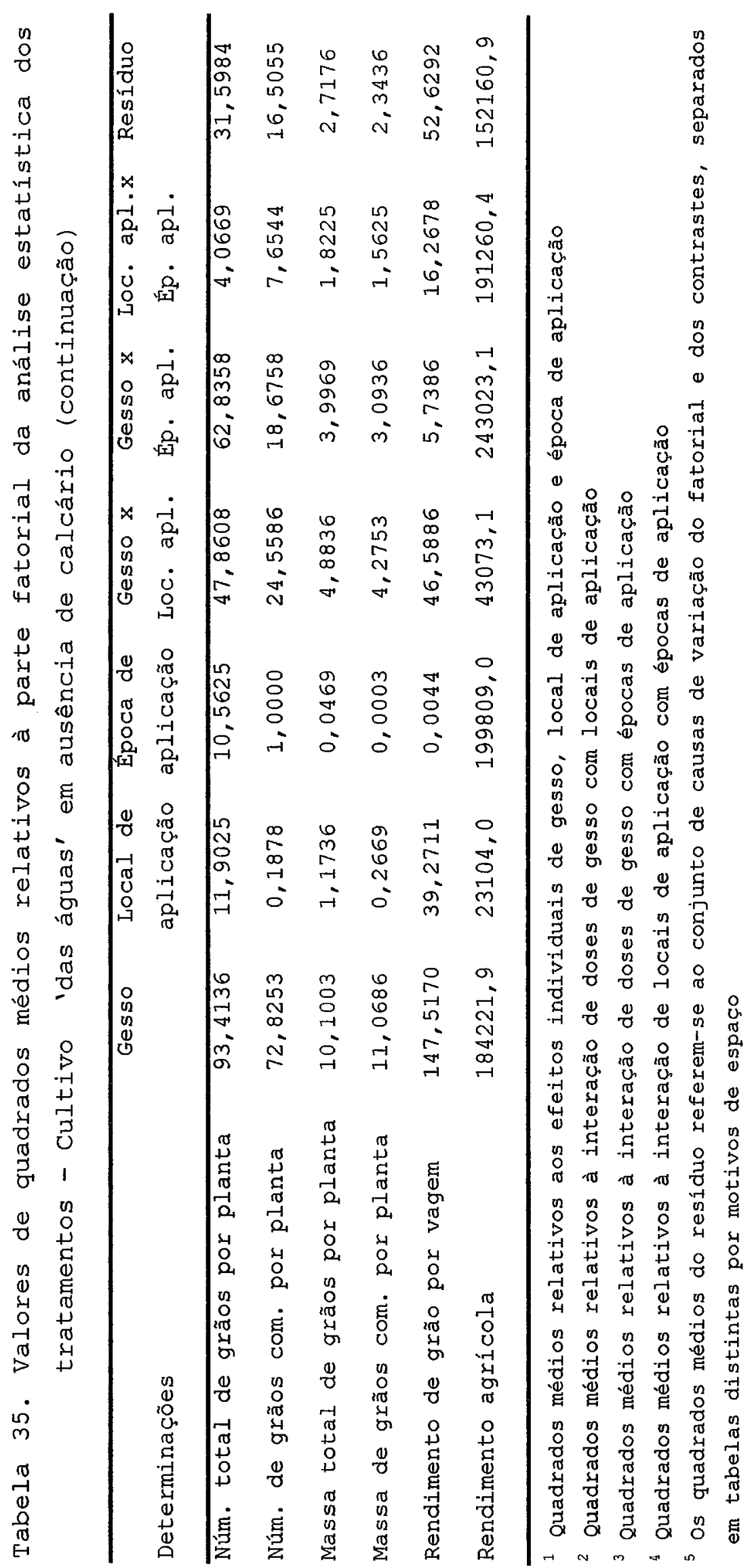




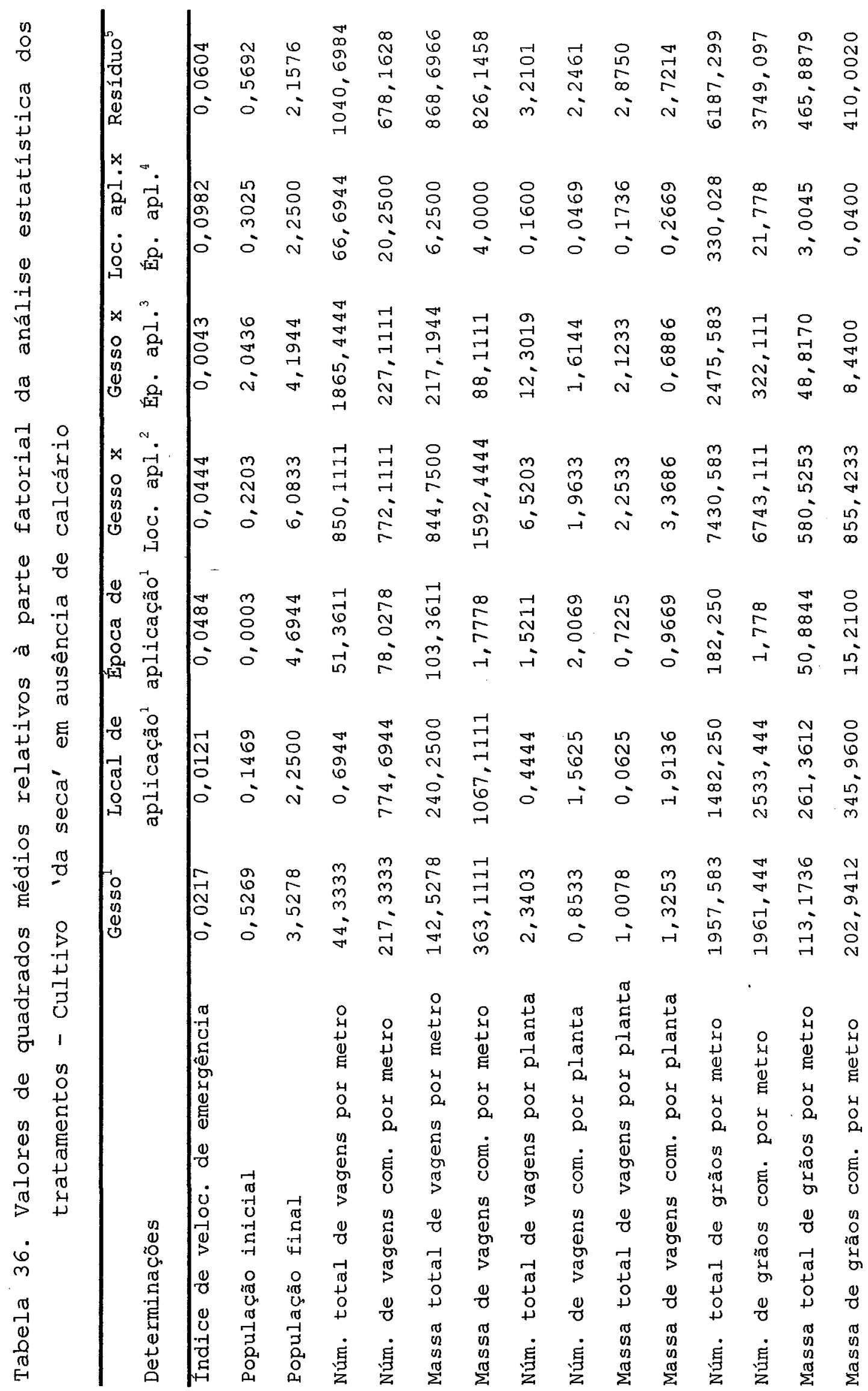




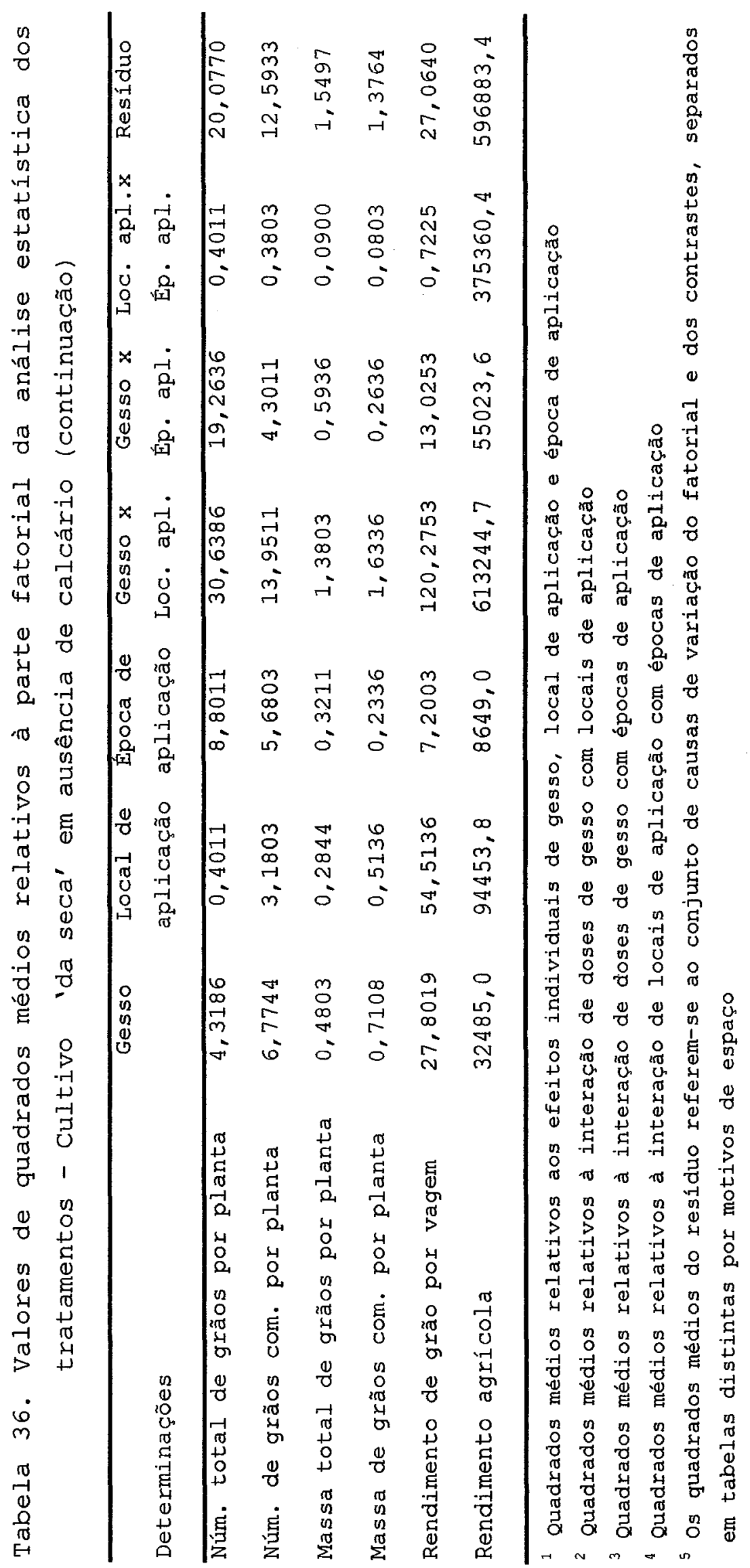




\section{REFERÊNCIAS BIBLIOGRÁFICAS}

ANUÁRIO ESTATÍSTICO DO BRASIL - 1994, v. 54, p. 3-27-28, 1994.

CÍCERO, S.M.; MARCOS FILHO, J.; SILVA, W.R. da. Avaliação da qualidade das sementes. Piracicaba: FEALQ, 1987. 230p.

COELHO, F.A.S. \& TELLA, R. Absorção de nutrientes pela planta de amendoim em cultura de primavera. Bragantia, v. 26, p.393-408, 1967.

FORNASIERI, J.L.; FERREIRA, M.E.; VITTI, G.C.; FORNASIERI FILHO, D. Efeitos do uso de calcário e de gesso agrícola sobre algumas caracteristicas produtivas do amendoim (Arachis hypogaea L.) "das águas". Cientifica, V. 15, n. 1/2, p. 45$54,1987$.

GALLO, P.A. Efeito do gesso agrícola na cultura de amendoim (Arachis hypogaea L.) em área de reforma de cana-de-açúcar, em oxissolos. Jaboticabal, 1987. 53 p. Trabalho (Graduação) - Faculdade de Ciências Agrárias e Veterinária de Jaboticabal, Universidade Estadual Paulista "Júlio de Mesquita Filho".

GODOY, I.J. de; RAZERA, L.F.; MORAES, S.A. de. A qualidade do amendoim: importância do cálcio. Campinas: Instituto Agronômico de Campinas, 1992. 20 p. (datilografado) 
GODOY, O.P.; MARCOS EILHO, J.; CÂMARA, G.M. de S. Tecnologia da Produção In: CÂMARA, G.M. de S.; GODOY, O.P.; MARCOS FILHO, J.; FONSECA, H. Amendoim: produção, pré-processamento e transformação agroindustrial. São Paulo: Secretaria da Indústria, Comércio, Ciência e Tecnologia, s.d. p. 1-38. (Série Extensão Agroindustrial, 3) .

GOMES, F.P. Curso de estatistica experimental. 13. ed. Piracicaba: Nobel, 1990. $430 \mathrm{p}$.

GUILHERME, M.R. Efeitos da aplicação de calcário calcinado, gesso agrícola e a mistura de calcário dolomítico calcinado e gesso agrícola em culturas de interesse econômico. Piracicaba, 1986. 56p. Dissertação (Mestrado) - Escola Superior de Agricultura "Luiz de Queiroz", Universidade de São Paulo.

LASCA, D.H. de C. Calagem merece atenção. Casa da Agricultura, v. 9, p. 26-27, mar./abr. 1987.

MALAVOLTA, E. Elementos de nutrição mineral de plantas. São Paulo: Agronômica Ceres, 1980. 251 p.

MALAVOLTA, E.; HAAG, A.P.; MELLO, F.A.P.; BRASIL SOBRINHO, M.O.C. Nutrição mineral de algumas culturas tropicais. São Paulo: Pioneira, 1967. $251 \mathrm{p}$.

NAKAGAWA, J.; SCOTON, L.C.; ALMEIDA, T. de C.; NEPTUNE, A.M.L. Adubação NPK, calagem e diagnose foliar do amendoim. Anais da Escola superior de Agricultura "Luiz de Queiroz", $v .23$, n. 1 , p. 369-377, 1966.

NEPTUNE, A.M.L.; SICHMANN, W.; MELLO, F.A.F. de; LASCA, D.H.C. Efeito da calagem na produção de amendoim cultivado em solos 
arenosos do Estado de São Paulo. I. Calagem com antecedência ao plantio. Anais da Escola superior de Agricultura "Luiz de Queiroz", v. 39, n. 1, p. 305-317, 1982.

NEPTUNE, A.M.L.; SICHMANN, W.; MELLO, F.A.F. de; LASCA, D.H.C. Efeito da calagem na produção de amendoim cultivado em solos arenosos do Estado de São Paulo. II. Calagem aplicada por ocasião do plantio. Anais da Escola superior de Agricultura "Luiz de Queiroz", v. 40, n. 1, p. 603-613, 1983.

QUAGGIO, J.A.; DECHEN, A.R.; RAIJ, B. van. Efeitos da aplicação de calcário e gesso agrícola sobre a produção de amendoim e lixiviação de bases no solo. Revista Brasileira de Ciência do Solo, v. 6, n. 3, p. 189-194, 1982.

RAIJ, B. van. Fertilidade do solo e adubação. São Paulo: Editora Agronômica Ceres; Associação Brasileira para Pesquisa da Potassa e do Fosfato, 1991. 343p.

RODRIGUES FILHO, F.S.O.; GODOY, I.J. de; FEITOSA, C.T. Acúmulo de matéria seca e nutrientes em plantas de amendoim cultivar Tatuí-76. Revista Brasileira de Ciência do Solo, v. 10, n. 1, p. 61-66, jan./abr. 1986 .

SELLESCOP, J.P.E. Amendoim: todos os aspectos da cultura. Gazeta do Agricultor, v. 25, n. 289, p. 184-187, jun. 1973.

SICHMANN, $\mathbf{w}$. Oleaginosas: clima, solo e adubação na cultura do amendoim. Revista Brasileira de Fertilizantes, Inseticidas e Rações (FIR), v. 8, n. 10, p. 14-18, jun. 1966.

SICHMANN, W. Amendoim e Cálcio. Revista Brasileira de Fertilizantes, Inseticidas e Rações (FIR), v. 10, n. 8, p. 35, abr. 1968 . 
SICHMANN, W.; NEPTUNE, A.M.L.; SABINO, N.P. Amendoim exige pouco nutriente do solo. Revista Brasileira de Fertilizantes, Inseticidas e Rações (FIR), v. 9, n. 6, p. 4-6, fev. 1967.

SICHMANN, W.; NEPTUNE, A.M.L.; SABINO, N.P. Acumulação de macronutrientes pelo amendoim (Arachis hypogaea I.) cultivado em outono, época seca. Anais da Escola Superior de Agricultura "Luiz de Queiroz", v. 27, p. 393-409, 1970.

SKELTON, B.J.; SHEAR, G.M. Calcium translocation in the peanut (Arachis hypogaea L.). Agronomy Journal, v. 63, p. 409-413, maio/jun. 1971.

SMITH, D.H.; WELLS, M.A.; PORTER, D.M.; COX, E.R. Peanut. In: BENNETT, W.E. Nutrient deficiences \& toxicities in crop plants. St. Paul: The American Phytopathological Society, 1994. capítulo 9, p. 105-110.

VELÁSQUEZ, L.; RAMÍREZ, R.; CASANOVA, E.; ADAMS, M. Efecto de la aplicacion de $\mathrm{Ca}$ en el medio de fructificacion del Mani (Arachis hypogaea L.). Agronomia Tropical, v.37, n. 4/6, p. 95-103, jul./dez. 1987.

VITTI, G.C. Macronutrientes secundários: situação, perspectivas e sugestões. Piracicaba: Escola Superior de Agricultura "Luiz de Queiroz", 1986. 37 p. (Mimeografado). 